Nadwa | Jurnal Pendidikan Islam

Vol. 8, Nomor 2, Oktober 2014

\title{
Pengembangan Model Perencanaan Himpunan Data dan Aplikasi Instrumentasi Berbasis Pola Tujuh Belas Plus
}

\author{
Indra Kusuma \\ Universitas Muhammadiyah Jember \\ Email: indrakusuma.kons335@gmail.com
}

\begin{abstract}
This paper describes the development of a set of data and planning models based instrumentation applications seventeen plus patterns in BK teachers SMP / MTs in Bondowoso. The results of this study indicate that counselling activity planning model using the approach pattern seventeen plus becomes very necessary. B.K. teachers in SMP/MTs of Bondowoso still do not have a wide range of data that should be held for the provision of counselling services. The teachers feel it is important to have variety of data sets and instrumentation applications for the smooth running of counselling services (score $=3.23$ ). The evaluation of the implementation of set of data and applications instrument was still very low (score $=1.14$ ). The planning model development activities and application instrumentation data set found that B.K. teachers desperately need (score $=4.28$ ). The assessment model development planning activities data set and instrumentation applications that are promoted rated excellent (score $=4.47$ ).
\end{abstract}

Keywords: planning, data set, application instrumentation

\begin{abstract}
Abstrak
Makalah ini menjelaskan pengembangan model perencanaan himpunan data dan aplikasi instrumentasi berbasis pola tujuh belas plus pada guru B.K. SMP/MTs di Bondowoso. Hasil penelitian ini menunjukkan bahwa model perencanaan kegiatan konseling dengan menggunakan pendekatan pola tujuh belas plus menjadi sangat perlu dilakukan agar implementasinya sesuai dengan kebutuhan siswa. Guru BK SMP/MTs di Bondowoso masih banyak yang belum memiliki berbagai data untuk penyelenggaraan layanan konseling. Guru-guru tersebut sangat memerlukan himpunan data dan aplikasi instrumentasi untuk kelancaran menjalankan tugasnya (rerata $=3,23$ ). Sementara evaluasi pelaksanaan himpunan data dan aplikasi instrumennya ternyata masih sangat rendah (rerata = 1,14. Guru-guru BK juga sangat membutuhkan (rerata $=4,28$ ). Penilaian pengembangan model perencanaan kegiatan himpunan data dan aplikasi instrumentasi yang dipromosikan dinilai sangat baik $(\mathrm{rata}=4,47)$
\end{abstract}

Kata kunci: perencanaan, himpunan data, aplikasi instrumentasi

ISSN 1979-1739

(C) 2014 Nadwa | IAIN Walisongo

http://journal.walisongo.ac.id/index.php/nadwa 


\section{A. Pendahuluan}

Setiap organisasi pendidikan perlu melakukan suatu perencanaan dalam setiap kegiatan organisasinya. Baik berupa perencanaan kegiatan, perencanaan kurikulum, program pembelajaran maupun perencanaan kegiatan konseling di sekolah. Perencanaan (planning) merupakan proses dasar bagi organisasi untuk memilih sasaran dan menetapkan bagaimana cara mencapainya. Oleh karena itu, perencanaan dalam pendidikan harus menetapkan tujuan dan sasaran yang hendak dicapai sebelum melakukan proses perencanaan yang lain, termasuk juga dalam hal ini adalah perencanaan kegiatan bimbingan dan konseling. ${ }^{1}$

Perencanaan merupakan tahapan paling penting dari suatu fungsi manajemen, terutama dalam menghadapi lingkungan eksternal yang berubah dinamis. Dalam era globalisasi ini, perencanaan harus lebih mengandalkan prosedur yang rasional dan sistematis, bukan sekadar pada intuisi dan firasat (dugaan).

Pokok pembahasan pada penelitian ini berfokus pada elemenelemen tertentu dari proses perencanaan dan proses yang sangat berhubungan dengan pemecahan masalah, serta pengembangan program layanan konseling di sekolah. Kemudian memperkenalkan konsep perencanaan dan menyajikan sejumlah pendekatan untuk mengefektifkan perencanaan dari kegiatan pendukung himpunan data dan aplikasi instrumentasi, dalam layanan konseling di sekolah maupun madrasah.

Berdasarkan latar belakang di atas, terutama yang terkait dengan perencanaan himpunan data dan aplikasi instrumentasi bagi guru BK/Konselor SMP/MTS di Kabupaten Bondowoso yang ada saat ini, maka dapat dirumuskan permasalahan penelitian sebagai berikut:

1. Bagaimana model perencanaan himpunan data dan aplikasi instrumentasi bagi guru BK/Konselor SMP/MTs di Kabupaten Bondowoso saat ini?

2. Bagaimana desain model perencanaan himpunan data dan aplikasi instrumentasi bagi guru BK/Konselor SMP/MTs di Kabupaten Bondowoso yang dipromosikan?

${ }^{1}$ Husaini Usman, Manajemen Teori Praktek dan Riset Pendidikan, (Jakarta: Bumi Aksara, 2008), hlm. 61. 
3. Bagaimana pengembangan model perencanaan himpunan data dan aplikasi instrumentasi bagi guru BK/Konselor SMP/MTS di Kabupaten Bondowoso yang dipromosikan?

\section{B. Konsep Perencanaan}

Konsep perencanaan menurut T. Hani Handoko, dapat dijelaskan sebagai berikut:

1. Proses menentukan bagaimana sistem manajemen akan mencapai tujuan dalam menentukan bagaimana organisasi dapat meraih apa yang ingin ditujunya.

2. Proses menetapkan tujuan-tujuan dan rancangan tindakan, membangun peraturan-peraturan dan prosedur, dan memperhitungkan hasil-hasil yang akan terjadi di waktu yang akan datang.

3. Proses perencanaan tidak berakhir bila rencana tersebut telah ditetapkan, namun perlu terus dimodifikasi sesuai dengan temuan-temuan baru di lapangan yang membawa pada efektivitas dan efisiensi organisasi. ${ }^{2}$

Pendapat yang lain menurut tim dosen administrasi pendidikan Universitas Pendidikan Indonesia, menjelaskan bahwa perencanaan sebagai bagian dari manajemen merupakan suatu proses yang sistematis dalam melakukan kegiatan organisasi. ${ }^{3}$ Proses manajemen secara umum harus mengikuti langkah-langkah merencanakan, mengorganisasikan, memimpin, dan mengendalikan. Berkaitan dengan perencanaan tersebut dapat diuraikan sebagai berikut:

1. Merencanakan adalah membuat suatu target-target yang akan dicapai atau diraih di masa depan. Dalam organisasi merencanakan adalah suatu proses memikirkan dan menetapkan secara matang terhadap arah, tujuan dan tindakan sekaligus mengkaji berbagai sumber daya dan metode atau teknik yang tepat.

2. Merencanakan pada dasarnya membuat keputusan mengenai arah yang akan dituju, tindakan yang akan diambil, sumber daya yang akan diolah dan teknik atau metode yang dipilih untuk digunakan. Rencana mengarahkan tujuan organisasi

${ }^{2}$ T. Hani Handoko, Manajemen, (Yogyakarta: BPFE, 2013), hlm. 7778.

${ }^{3}$ Tim dosen UPI, Manajemen Pendidikan, (Bandung: Alfabeta, 2012), hlm. 93-94. 
dan menetapkan prosedur terbaik untuk mencapainya. Prosedur itu dapat berupa pengaturan sumber daya dan penetapan teknik atau metode.

3. Keberadaan suatu rencana sangat penting bagi organisasi, sebab rencana berfungsi untuk: Menjelaskan dan merinci tujuan yang ingin dicapai, Memberikan pegangan dan menetapkan kegiatan-kegiatan yang harus dilakukan untuk mencapai tujuan tersebut, Organisasi memperoleh standar sumber daya terbaik dan mendayagunakannya sesuai tugas pokok fungsi yang telah ditetapkan. Di sisi lain, menjadi rujukan anggota organisasi dalam melaksanakan aktivitas yang konsisten prosedur dan tujuan, Memberikan batas kewenangan dan tanggung jawab bagi seluruh pelaksana, Memonitor dan mengukur berbagai keberhasilan secara intensif sehingga bisa menemukan dan memperbaiki penyimpangan secara dini, Memungkinkan untuk terpeliharanya persesuaian antara kegiatan internal dengan situasi eksternal, Menghindari pemborosan.

Pendapat yang hampir sama juga disampaikan oleh Heidjrachman Ranu Pandojo. Perencanaan merupakan aspek administrasi yang bersifat khusus, dan keberhasilannya sangat bergantung pada standar dan informasi yang akurat. Kegiatan perencanaan akan meliputi perencanaan garis besar perencanaan, strategi atau program umum, pemilihan metode yang cocok, pemilihan bahan baku dan mesin-mesin yang tepat, dan berbagai hal dalam rangka menjawab pertanyaan $5 \mathrm{~W}+1 \mathrm{H}$ (apa, mengapa, bagaimana, kapan, di mana, oleh siapa) pelaksanaan pekerjaan dijalankan. Kegiatan perencanaan akan meliputi: informasi tentang latar belakang, kehendak yang diinginkan, metode yang akan dipergunakan, administrasi yang rinci, dan sistem interkomunikasi. ${ }^{4}$

Proses perencanaan ini, biasanya mengenai hal-hal yang bersifat eksklusif, yakni berkenaan dengan kegiatan operasional yang akan dilaksanakan, seperti tanggung jawab masing-masing departemen, penentuan tugas-tugas departemen dan lain-lain. Beberapa kegiatan yang direncanakan adalah penyusunan program kerja berkaitan dengan rencana pembelajaran, strategi

4 Heidjrachman Ranupandojo, Teori dan Konsep Manajemen, (Yogyakarta: UPP AMP YKPN, 1996), hlm. 59-60. 
pembelajaran, waktu, metode, juga jadwal mengajar (bagi lembaga pendidikan) dan lain-lain.

Agar perencanaan berdaya guna, maka perencanaan harus sederhana, luwes, berimbang, didasarkan pada standar-standar yang akurat hasil observasi dan pencatatan sistematis. Perencanaan merupakan alat manajemen penting, karena itu perlu diberikan perhatian khusus, serta imajinasi yang kuat didasari pengetahuan teknik yang luas dan mendalam. Namun perlu diingat, merencanakan bukan satu-satunya kegiatan manajemen, karena dalam penerapan rencana tersebut, akan sangat tergantung pada pelaksanaannya. Hal ini merupakan salah satu kunci keberhasilan perencanaan, yaitu tersedianya pelaksanaan-pelaksanaan yang baik.

Dari keterangan di atas dapat kita simpulkan bahwa perencanaan merupakan proses awal bagi sistem manajemen untuk mencapai tujuan-tujuannya. Oleh sebab itu, perencanaan merupakan proses menentukan rancangan tindakan bagaimana organisasi membangun aturan-aturan dan prosedur demi tercapainya tujuan organisasi tanpa melupakan kemungkinankemungkinan yang akan terjadi dalam pelaksanaan perencanaan. Perencanaan yang dilakukan oleh organisasi termasuk dalam hal ini adalah organisasi bimbingan dan konseling di sekolah (Unit Pelayanan Bimbingan dan Konseling, disingkat UPBK) harus bersifat fleksibel. Artinya perencanaan tersebut bisa menyesuaikan terhadap lingkungan eksternal (kebutuhan perkembangan klien) yang dinamis.

\section{Alasan Pentingnya Perencanaan Dalam Manajemen}

Ada beberapa alasan mengapa perencanaan begitu penting terhadap Manajemen Organisasi, menurut T. Hani Handoko sebagai berikut:

1. Tujuan organisasi menjadi jelas dan terarah. Perencanaan sebagai langkah awal dari pencapaian tujuan akan memberikan arah dan kejelasan tujuan tersebut, sehingga semua komponen ataupun elemen-elemen dalam organisasi mengetahui dengan baik tujuan yang hendak dicapai.

2. Semua bagian yang ada dalam organisasi akan bekerja ke arah satu tujuan yang sama ketika semua elemen atau bagian dalam organisasi mengetahui tujuan organisasinya dengan jelas dan benar, maka mereka akan bekerja ke satu arah yang sama. 
Artinya mereka memahami prosedur apa saja yang akan dilakukan sebagaimana yang telah mereka sepakati dalam perencanaan.

3. Menolong mengidentifikasi berbagai hambatan dan peluang. Dengan adanya perencanaan maka organisasi mampu mengidentifikasi berbagai hambatan dan peluang yang ada di lingkungan luar organisasi. Adanya hambatan dan peluang yang datang akan menuntut organisasi mempersiapkan tindakan-tindakan antisipasi ke depan sehingga mereka tetap berada di jalur menuju tujuan awal.

4. Membantu pekerjaan menjadi lebih efisien dan efektif. Perencanaan memberikan pandangan bagi organisasi mengenai tindakan apa saja yang harus mereka lakukan demi tercapainya tujuan, termasuk di dalamnya biaya dan lamanya waktu yang dibutuhkan sehingga tujuan terealisasi. Hal ini akan membantu organisasi menjadi lebih efektif dan efisien dalam mencapai tujuan.

5. Perencanaan sendiri dapat diartikan aktivitas pengawasan. Ketika prosedur kerja sudah ada dan jelas, tentu hal ini menjadi sebuah kontrol terhadap pelaksanaan di lapangan. Artinya mereka akan bekerja sesuai prosedur sebab perencanaan bertindak sebagai pengawasan. ${ }^{5}$

6. Perencanaan juga membantu untuk mengurangi risiko dan ketidakpastian. Dalam mencapai sebuah tujuan, terdapat berbagai macam risiko dan ketidakpastian yang akan menghadang dalam pencapaian tujuan organisasi. Oleh karena itu, adanya perencanaan akan memperjelas tindakan-tindakan dan prosedur kerja sehingga ketidakpastian tersebut dapat diminimalkan.

Dalam manajemen, perencanaan adalah proses mendefinisikan tujuan organisasi, membuat strategi untuk mencapai tujuan, dan mengembangkan rencana aktivitas kerja organisasi. Perencanaan merupakan proses terpenting dari semua fungsi manajemen karena tanpa perencanaan fungsi-fungsi lain seperti pengorganisasian, pengarahan, dan pengontrolan tidak akan dapat berjalan. ${ }^{6}$

${ }^{5}$ Handoko, Manajemen, hlm. 80-81.

${ }^{6}$ Nanang Fatah, Landasan Manajemen Pendidikan, (Bandung: Remaja Rosdakarya, 2008), hlm. 11. 
Demikian pula dalam manajemen bimbingan dan konseling, perencanaan adalah proses mendefinisikan tujuan layanan konseling di sekolah, serta membuat strategi untuk mencapai tujuan konseling, dan mengembangkan rencana aktivitas layanan konseling. Sehingga Perencanaan kegiatan konseling di sekolah merupakan proses terpenting dari semua fungsi manajemen konseling, karena tanpa perencanaan yang baik fungsi-fungsi manajemen konseling lain seperti pengorganisasian, pengarahan, dan pengontrolan tidak akan dapat berjalan.

Sebagai bagian dari pendidikan, konseling adalah pendidikan, sementara dalam Undang-Undang Nomor 20 Tahun 2003 tentang Sistem Pendidikan Nasional (Sisdiknas) dinyatakan bahwa pendidikan adalah usaha sadar dan terencana untuk mewujudkan suasana dalam belajar dan proses pembelajaran agar peserta didik secara aktif mengembangkan potensi dirinya untuk memiliki kekuatan spiritual keagamaan, pengendalian diri, kepribadian, kecerdasan, akhlak mulia serta keterampilan yang diperoleh dirinya, masyarakat, bangsa dan negara. ${ }^{7}$

Merujuk pada penjelasan di atas, maka layanan konseling di sekolah harus dilakukan dengan membuat perencanaan kegiatan yang sesuai dengan tujuan pendidikan. Salah satu kegiatan perencanaan yang perlu dilakukan ialah perencanaan himpunan data dan aplikasi instrumentasi bagi guru BK/Konselor SMP/MTS di Kabupaten Bondowoso.

\section{Bimbingan dan Konseling Berbasis Tujuh Belas Plus}

Menurut Prayitno, sejak tahun 1993 penyelenggaraan pelayanan bimbingan dan konseling (BK) di sekolah memperoleh perbendaharaan istilah baru,yaitu BK Pola-17. Istilah tersebut memberikan warna tersendiri bagi arah dan bidang, jenis layanan dan kegiatan, serta substansi pelayanan BK di jajaran pendidikan dasar dan menengah. ${ }^{8}$

Seiring dengan mulai dikenalnya BK pola-17 waktu itu, kini berkembang menjadi BK Pola-17 plus,terutama apabila kegiatan BK mengacu kepada sasaran pelayanan yang lebih luas, sehingga

\footnotetext{
${ }^{7}$ Undang-undang Sistem Pendidikan Nomor 20 Tahun 2003.

${ }^{8}$ Prayitno, Seri Panduan Layanan Dan Kegiatan Pendukung Konseling, (Padang: FIP UNP, 2012), hlm. 1-3.
} 
mencakup peserta didik di perguruan tinggi dan warga masyarakat luas.

Secara menyeluruh, butir-butir pokok BK Pola-17 plus itu adalah:

1. Keterpaduan mantap tentang pengertian, tujuan, fungsi, prinsip dan asas, serta landasan BK.

2. Bidang pelayanan BK, meliputi: bidang pengembangan pribadi, bidang pengembangan sosial, bidang pengembangan kegiatan belajar, bidang pengembangan karier, bidang pengembangan kehidupan berkeluarga, bidang pengembangan kehidupan beragama.

3. Jenis layanan BK, meliputi: layanan orientasi, layanan informasi, layanan penempatan dan penyaluran, layanan penguasaan isi, layanan konseling perorangan, layanan bimbingan kelompok, layanan konseling kelompok, layanan konsultasi, layanan mediasi.

4. Kegiatan pendukung BK, meliputi: aplikasi instrumentasi, himpunan data, konferensi kasus, kunjungan rumah, alih tangan kasus.

5. Format pelayanan meliputi: format individual, format kelompok, format klasikal, format lapangan, format khusus.

Perencanaan kegiatan konseling dengan menggunakan pendekatan pola tujuh belas plus, menjadi sangat perlu dilakukan oleh guru BK agar implementasinya sesuai dengan kebutuhan siswa di lapangan. Hal inilah yang meyakinkan bagi penulis untuk dikembangkan model perencanaan tersebut sesuai dengan kebutuhan di sekolah.

\section{E. Model Perencanaan Himpunan Data dan Aplikasi Instrumentasi bagi Guru BK/Konselor}

Dari penjelasan dan pembahasan di atas, penulis telah mengumpulkan data angket dan wawancara di lapangan kepada guru BK/Konselor di Kabupaten Bondowoso (Tabel 1), bahwa sebagian besar mereka belum mampu membuat perencanaan kegiatan himpunan data dan aplikasi instrumentasi untuk layanan konseling di sekolah berbasis pola tujuh belas plus yang merupakan embrio dari layanan bimbingan konseling kurikulum 2013. Data tersebut dapat dijelaskan seperti tabel berikut ini: 
Tabel 1

Data tentang Himpunan Data dan Aplikasi Instrumentasi

\begin{tabular}{llrrrrr}
\hline \multirow{2}{*}{ No. } & \multirow{2}{*}{ Pernyataan-pernyataan } & \multicolumn{3}{c}{ Jawaban } & \multirow{2}{*}{$\begin{array}{c}\text { Jumlah } \\
\text { Total }\end{array}$} \\
\cline { 3 - 6 } & & A & \% & \multicolumn{1}{c}{ B } & \% & \\
\hline 1 & Riwayat hidup setiap siswa & 30 & 94 & 2 & 6 & 32 \\
\hline 2 & Intelegensi siswa & 3 & 10 & 29 & 90 & 32 \\
\hline 3 & Prestasi akademik siswa & 31 & 96 & 1 & 4 & 32 \\
\hline 4 & Prestasi nonakademik siswa & 21 & 65 & 11 & 35 & 32 \\
\hline 5 & Bakat siswa & 15 & 47 & 17 & 53 & 32 \\
\hline 6 & Minat siswa & 16 & 50 & 16 & 50 & 32 \\
\hline 7 & Riwayat kesehatan siswa & 16 & 50 & 16 & 50 & 32 \\
\hline 8 & Keahlian khusus siswa & 5 & 16 & 27 & 84 & 32 \\
\hline 9 & Permasalahan siswa & 32 & 100 & 0 & 0 & 32 \\
\hline 10 & Sosiogram siswa & 28 & 87 & 4 & 13 & 32 \\
\hline 11 & Teman dekat setiap siswa & 15 & 47 & 17 & 53 & 32 \\
\hline 12 & Nilai hasil belajar siswa & 29 & 90 & 3 & 10 & 32 \\
\hline 13 & Kegiatan belajar siswa & 19 & 59 & 13 & 41 & 32 \\
\hline 14 & Riwayat pendidikan siswa & 29 & 90 & 3 & 10 & 32 \\
\hline 15 & Peminatan studi siswa & 11 & 35 & 21 & 65 & 32 \\
\hline 16 & Riwayat pendidikan dan & 25 & 78 & 7 & 22 & 32 \\
& pekerjaan orang tua siswa & & & & \\
\hline 17 & Perencanaan karier siswa & 13 & 41 & 19 & 59 & 32 \\
\hline
\end{tabular}

Keterangan: $(\mathrm{A}=\mathrm{Ada}$, dan $\mathrm{B}=$ Tidak Ada $)$

Sementara itu sebagian besar guru BK/Konselor SMP/MTS di Bondowoso, berasumsi bahwa berbagai kegiatan dalam himpunan data dan aplikasi instrumentasi adalah sangat penting bagi mereka untuk mengembangkan program kegiatan layanan konseling di sekolah, seperti yang dijelaskan pada ( tabel. 2).

Tabel 2

Rekapitulasi Pentingnya Kegiatan Himpunan Data dan Aplikasi Instrumentasi

\begin{tabular}{llccc}
\hline No & Pernyataan-pernyataan & Skor & $\begin{array}{c}\text { Rata- } \\
\text { rata }\end{array}$ & Kategori \\
\hline 1 & Riwayat hidup setiap siswa & 121 & 3.78 & SP \\
\hline 2 & Intelegensi siswa & 92 & 2.87 & $\mathrm{P}$ \\
\hline 3 & Prestasi akademik siswa & 111 & 3.46 & $\mathrm{SP}$ \\
\hline
\end{tabular}




\begin{tabular}{clccc}
\hline 4 & Prestasi nonakademik siswa & 107 & 3.34 & SP \\
\hline 5 & Bakat siswa & 109 & 3.40 & SP \\
\hline 6 & Minat siswa & 112 & 3.5 & $\mathrm{SP}$ \\
\hline 7 & Riwayat kesehatan siswa & 94 & 2.93 & $\mathrm{P}$ \\
\hline 8 & Keahlian khusus siswa & 92 & 2.87 & $\mathrm{P}$ \\
\hline 9 & Permasalahan siswa & 115 & 3.59 & $\mathrm{SP}$ \\
\hline 10 & Sosiogram siswa & 104 & 3.25 & $\mathrm{SP}$ \\
\hline 11 & Teman dekat setiap siswa & 95 & 2.96 & $\mathrm{P}$ \\
\hline 12 & Nilai hasil belajar siswa & 110 & 3.43 & $\mathrm{SP}$ \\
\hline 13 & Kegiatan belajar siswa & 102 & 3.18 & $\mathrm{P}$ \\
\hline 14 & Riwayat pendidikan siswa & 99 & 3.09 & $\mathrm{P}$ \\
\hline 15 & Peminatan studi siswa & 96 & 3 & $\mathrm{P}$ \\
\hline 16 & Riwayat pendidikan dan pekerjaan & 106 & 3.31 & $\mathrm{SP}$ \\
& orang tua siswa & & & \\
\hline 17 & Perencanaan karier siswa & 99 & 3.09 & $\mathrm{p}$ \\
\hline
\end{tabular}

Keterangan:

$\begin{array}{lll}0.00-0.80 & =\mathrm{TP} & \text { (Tidak Penting) } \\ 0.81-1.60 & =\mathrm{KP} & \text { (Kurang Penting) } \\ 1.61-2.40 & =\mathrm{AP} & \text { (Agak Penting) } \\ 2.41-3.20 & =\mathrm{P} \quad \text { (Penting) } \\ 3.21-4.00 & =\mathrm{SP} & \text { (Sangat Penting) }\end{array}$

Dari studi pendahuluan dalam (Tabel 1) dapat disimpulkan bahwa secara umum guru BK SMP/MTS di Bondowoso masih banyak yang belum memiliki berbagai data yang hendaknya dimiliki untuk penyelenggaraan layanan konseling di sekolah. Dari data (Tabel 2),secara umum guru BK SMP/MTS di Bondowoso merasakan penting dan bahkan sangat penting untuk memiliki berbagai himpunan data dan aplikasi instrumentasi, untuk kelancaran tugasnya dalam menjalankan layanan konseling di sekolah, dengan skor rata-rata $=3,23$. Selain itu dapat pula dijelaskan pada (tabel 3) tentang evaluasi pelaksanaan himpunan data dan aplikasi instrumentasi yang bisa disimpulkan bahwa secara umum masih sangat rendah, dengan skor rata-rata $=1,14$. Sementara pada (tabel 4) tentang kebutuhan untuk pengembangan model perencanaan kegiatan himpunan data dan aplikasi instrumentasi ditemukan bahwa secara umum guru BK sangat membutuhkan, dengan skor rata-rata $=4,28$. 


\section{Rekapitulasi Angket Evaluasi Kegiatan Himpunan Data dan Aplikasi Instrumentasi}

\begin{tabular}{clccc}
\hline No & \multicolumn{1}{c}{ Pernyataan-pernyataan } & Skor & $\begin{array}{c}\text { Rata- } \\
\text { rata }\end{array}$ & $\begin{array}{c}\text { Kate- } \\
\text { gori }\end{array}$ \\
\hline 1 & $\begin{array}{l}\text { Model perencanaan tentang himpunan } \\
\text { data setiap siswa yang ada saat ini }\end{array}$ & 45 & 1,8 & R \\
\hline 2 & $\begin{array}{l}\text { Model perencanaan tentang multipel } \\
\text { intelegensi siswa yang ada saat ini }\end{array}$ & 24 & 1 & SR \\
\hline 3 & $\begin{array}{l}\text { Model perencanaan tentang minat } \\
\text { SMA/MA yang ada saat ini }\end{array}$ & 24 & 1 & SR \\
\hline 4 & $\begin{array}{l}\text { Model perencanaan minat SMK yang ada } \\
\text { saat ini }\end{array}$ & 24 & 1 & SR \\
\hline 5 & $\begin{array}{l}\text { Model perencanaan tentang Penyesuaian } \\
\text { Diri yang ada saat ini }\end{array}$ & 24 & 1 & SR \\
\hline 6 & $\begin{array}{l}\text { Model perencanaan tentang Alat Ungkap } \\
\text { Masalah yang ada saat ini }\end{array}$ & 34 & 1,4 & SR \\
\hline 7 & $\begin{array}{l}\text { Model perencanaan tentang Sosiometri } \\
\text { yang ada saat ini }\end{array}$ & 30 & 1,2 & SR \\
\hline 8 & $\begin{array}{l}\text { Model perencanaan tentang Minat } \\
\text { Jabatan yang ada saat ini }\end{array}$ & 25 & 1,04 & SR \\
\hline 9 & $\begin{array}{l}\text { Model perencanaan tentang Daftar Cek } \\
\text { Masalah yang ada saat ini }\end{array}$ & 24 & 1 & SR \\
\hline 10 & $\begin{array}{l}\text { Model perencanaan tentang Alat Ungkap } \\
\text { Masalah PTSDL yang ada saat ini }\end{array}$ & 25 & 1,04 & SR \\
\hline
\end{tabular}

Keterangan:

$1,0-1,7=$ Sangat Rendah $(\mathrm{SR})$

$1,8-2,6=$ Rendah $(\mathrm{R})$

$2,7-3,4=$ Cukup $(\mathrm{C})$

$3,5-4,2=$ Baik $(B)$

$4,3-5,0=$ Sangat Baik (SB)

Tabel 4

Rekapitulasi Kebutuhan Kegiatan Himpunan Data dan Aplikasi Instrumentasi

\begin{tabular}{clccc}
\hline No & \multicolumn{1}{c}{ Pernyataan-pernyataan } & Skor & $\begin{array}{c}\text { Rata- } \\
\text { rata }\end{array}$ & $\begin{array}{c}\text { Kate- } \\
\text { gori }\end{array}$ \\
\hline 1 & $\begin{array}{l}\text { model perencanaan tentang } \\
\text { himpunan data setiap siswa }\end{array}$ & 112 & 4,48 & SB \\
\hline 2 & $\begin{array}{l}\text { model perencanaan tentang multipel } \\
\text { intelegensi siswa }\end{array}$ & 105 & 4,2 & $\mathrm{~B}$ \\
\hline 3 & model perencanaan tentang minat & 110 & 4,4 & $\mathrm{SB}$ \\
\hline
\end{tabular}




\begin{tabular}{clccc}
\hline \multicolumn{2}{l}{ SMA/MA } & & & \\
\hline 4 & model perencanaan minat SMK & 103 & 4,12 & B \\
\hline 5 & $\begin{array}{l}\text { model perencanaan tentang } \\
\text { penyesuaian diri }\end{array}$ & 101 & 4,04 & $\mathrm{~B}$ \\
\hline 6 & $\begin{array}{l}\text { model perencanaan tentang alat } \\
\text { ungkap masalah }\end{array}$ & 109 & 4,36 & $\mathrm{SB}$ \\
\hline 7 & $\begin{array}{l}\text { model perencanaan tentang } \\
\text { sosiometri }\end{array}$ & 109 & 4,36 & $\mathrm{SB}$ \\
\hline 8 & $\begin{array}{l}\text { model perencanaan tentang minat } \\
\text { jabatan }\end{array}$ & 103 & 4,12 & $\mathrm{~B}$ \\
\hline 9 & $\begin{array}{l}\text { model perencanaan tentang daftar } \\
\text { cek masalah }\end{array}$ & 108 & 4,32 & $\mathrm{SB}$ \\
\hline 10 & $\begin{array}{l}\text { model perencanaan tentang alat } \\
\text { ungkap masalah }\end{array}$ & 111 & 4,44 & $\mathrm{SB}$ \\
\hline
\end{tabular}

Keterangan:

$$
\begin{aligned}
1,0-1,7 & =\text { Tidak Butuh }(\mathrm{TB}) \\
1,8-2,6 & =\text { Kurang Butuh }(\mathrm{KB}) \\
2,7-3,4 & =\text { Cukup Butuh }(\mathrm{CB}) \\
3,5-4,2 & =\text { Butuh }(\mathrm{B}) \\
4,3-5,0 & =\text { Sangat Butuh }(\mathrm{SB})
\end{aligned}
$$

Selain dari data angket tersebut di atas, hasil wawancara penulis dengan guru BK di SMP/MTs Bondowoso berkaitan dengan pertanyaan bagaimana perencanaan yang dilakukan guru BK SMP/MTs terkait dengan himpunan data dan aplikasi instrumentasi, keterangan dari ibu SM diungkapkan sebagai berikut:

Selama ini saya tidak pernah membuat perencanaan yang detail terkait layanan konseling maupun kegiatan konseling di sekolah, saya hanya membuat rencana pelayanan konseling seperti yang telah diberikan dalam kegiatan di MGBK (Musyawarah Guru Bimbingan Dan Konseling), dari pertemuan dan kegiatan tersebut saya memperoleh banyak hal terkait kegiatan konseling di sekolah". (W.1.SM)

Semakna dengan penjelasan di atas, keterangan dari Pak HS juga diungkapkan sebagai berikut:

Perencanaan yang saya lakukan untuk layanan konseling maupun kegiatan konseling di sekolah, saya mencontoh perencanaan yang saya baca dari buku panduan pengembangan diri khususnya kegiatan pelayanan konseling, selain itu juga saya dapatkan dalam kegiatan MGBK, dari kegiatan tersebut saya membuat perencanaan kegiatan konseling di sekolah secara keseluruhan.“(W.1.HS)

Berdasarkan survei lapangan tersebut, penulis sangat berkepentingan dan berminat untuk meneliti dan membantu guru $\mathrm{BK} /$ Konselor agar mampu mengembangkan perencanaan 
pelayanan konselingnya di sekolah yang sesuai dengan kebutuhan siswa untuk berkembang kehidupan efektif sehari-harinya dan menangani kehidupan efektif sehari-hari yang terganggu dengan fokus pribadi mandiri dan mampu mengendalikan diri.

\section{F. Desain dan Pengembangan Model Perencanaan Himpunan Data dan Aplikasi Instrumentasi}

Berdasarkan proses pengumpulan data, peneliti akan menyusun pengembangan model sementara, yang diharapkan dapat dijadikan embrio untuk merumuskan model pengembangan dalam penelitian ini. Elemen atau unsur rancangan model meliputi: (tabel 5) model perencanaan himpunan data guru BK/Konselor, dan (tabel 6) model perencanaan aplikasi instrumentasi guru BK/Konselor. Gambaran model tersebut dapat diilustrasikan melalui tabel berikut:

Tabel 5

Model Perencanaan Himpunan Data

Guru BK/Konselor SMP/MTS di Kabupaten Bondowoso

\begin{tabular}{ll}
\hline \multicolumn{1}{c}{ Jenis Model } & \multicolumn{1}{c}{ Unsur/Elemen dalam Model } \\
\hline & Riwayat hidup setiap siswa \\
Intelegensi siswa & Prestasi akademik siswa \\
& Prestasi non akademik siswa \\
& Bakat siswa \\
& Minat siswa \\
& Riwayat kesehatan siswa \\
Perencanaan Himpunan Data & Keahlian khusus siswa \\
Guru BK/Konselor & Permasalahan siswa \\
SMP/MTs di Kabupaten & Sosiogram siswa \\
Bondowoso & Teman dekat setiap siswa \\
& Nilai hasil belajar siswa \\
& Kegiatan belajar siswa \\
& Riwayat pendidikan siswa \\
& Peminatan studi siswa \\
& Riwayat pendidikan dan pekerjaan orang \\
& tua siswa \\
& Perencanaan karier siswa \\
\hline
\end{tabular}

Tabel 6

Model Perencanaan Aplikasi Instrumentasi 


\begin{tabular}{ll}
\hline \multicolumn{1}{c}{ Jenis Model } & \multicolumn{1}{c}{ Unsur/Elemen dalam Model } \\
\hline pengembangan & perencanaan tentang multipel intelegensi siswa \\
model perencanaan & perencanaan tentang minat SMA/MA \\
aplikasi & perencanaan minat SMK \\
instrumentasi guru & perencanaan tentang penyesuaian diri \\
BK/Konselor & perencanaan tentang alat ungkap masalah \\
SMP/MTS di & perencanaan tentang sosiometri \\
Kabupaten & perencanaan tentang minat jabatan \\
Bondowoso & perencanaan tentang daftar cek masalah \\
& perencanaan tentang alat ungkap masalah PTSDL \\
\hline
\end{tabular}

Berdasarkan proses pengumpulan data, peneliti memperoleh data dari (Tabel 7) berkaitan dengan penilaian guru BK/Konselor SMP/MTS di Bondowoso terkait pengembangan model himpunan data dan aplikasi instrumentasi didapatkan data sangat baik dengan skor rata-rata $=4,47$, dapat dilihat pada tabel sebagai berikut:

\section{Tabel 7}

Rekapitulasi Penilaian Pengembangan

Model Himpunan Data dan Aplikasi Instrumentasi

\begin{tabular}{clccc}
\hline No & \multicolumn{1}{c}{ Pernyataan-pernyataan } & Skor & $\begin{array}{c}\text { Rata- } \\
\text { rata }\end{array}$ & Kategori \\
\hline 1 & $\begin{array}{l}\text { Model perencanaan tentang } \\
\text { himpunan data setiap siswa }\end{array}$ & 131 & 4,8 & SB \\
\hline 2 & $\begin{array}{l}\text { Model perencanaan tentang } \\
\text { multipel intelegensi siswa }\end{array}$ & 128 & 4,7 & SB \\
\hline 3 & $\begin{array}{l}\text { Model perencanaan tentang minat } \\
\text { SMA/MA }\end{array}$ & 110 & 4,0 & $\mathrm{~B}$ \\
\hline 4 & Model perencanaan minat SMK & 111 & 4,1 & $\mathrm{~B}$ \\
\hline 5 & $\begin{array}{l}\text { Model perencanaan tentang } \\
\text { Penyesuaian Diri }\end{array}$ & 123 & 4,5 & $\mathrm{SB}$ \\
\hline 6 & $\begin{array}{l}\text { Model perencanaan tentang Alat } \\
\text { Ungkap Masalah }\end{array}$ & 127 & 4,7 & $\mathrm{SB}$ \\
\hline 7 & $\begin{array}{l}\text { Model perencanaan tentang } \\
\text { Sosiometri }\end{array}$ & 113 & 4,1 & $\mathrm{~B}$ \\
\hline 8 & $\begin{array}{l}\text { Model perencanaan tentang Minat } \\
\text { Jabatan }\end{array}$ & 119 & 4,4 & $\mathrm{SB}$ \\
\hline 9 & $\begin{array}{l}\text { Model perencanaan tentang Daftar } \\
\text { Cek Masalah }\end{array}$ & 129 & 4,77 & $\mathrm{SB}$ \\
\hline 10 & $\begin{array}{l}\text { Model perencanaan tentang Alat } \\
\text { Ungkap Masalah PTSDL }\end{array}$ & 127 & 4,7 & $\mathrm{SB}$ \\
\hline
\end{tabular}

$1,0-1,7=$ Sangat Rendah $(\mathrm{SR})$

$1,8-2,6=$ Rendah $(\mathrm{R})$ 
$2,7-3,4=$ Cukup $(\mathrm{C})$

$3,5-4,2=$ Baik $($ B $)$

$4,3-5,0=$ Sangat Baik $(\mathrm{SB})$

\section{H. Penutup}

Berdasarkan proses pengumpulan data dalam penelitian ini, peneliti memperoleh simpulan berkaitan dengan pengembangan model himpunan data dan aplikasi instrumentasi guru BK/Konselor SMP/MTS di Bondowoso sebagai berikut:

1. Bahwa dari studi pendahuluan dapat disimpulkan bahwa secara umum guru BK SMP/MTS di Bondowoso masih banyak yang belum memiliki berbagai data, untuk penyelenggaraan layanan konseling di sekolah.

2. Secara umum guru BK SMP/MTS di Bondowoso merasakan penting dan bahkan sangat penting untuk memiliki berbagai himpunan data dan aplikasi instrumentasi, untuk kelancaran tugasnya dalam menjalankan layanan konseling di sekolah, dengan skor rata-rata $=3,23$.

3. Selain itu dapat pula dijelaskan tentang evaluasi pelaksanaan himpunan data dan aplikasi instrumentasi yang ada saat ini, bisa disimpulkan bahwa secara umum masih sangat rendah, dengan skor rata-rata $=1,14$.

4. Sementara terkait dengan kebutuhan untuk pengembangan model perencanaan kegiatan himpunan data dan aplikasi instrumentasi ditemukan bahwa secara umum guru BK sangat membutuhkan, dengan skor rata-rata $=4,28$.

5. Sedangkan terkait dengan penilaian pengembangan model perencanaan kegiatan himpunan data dan aplikasi instrumentasi yang dipromosikan, ditemukan bahwa secara umum guru BK memberi penilaian sangat baik, dengan skor rata-rata $=4,47$.

\section{Kepustakaan}

Afifuddin \& Ahmad Sabeni, Metodologi Penelitian Kualitatif. (Bandung: Pustaka Setia, 2009).

Fatah, Nanang, Landasan Manajemen Pendidikan, (Bandung: Remaja Rosda Karya, 2008). 
Hadi, Amirul, Metodologi Penelitian Pendidikan, (Bandung: Pustaka Setia, 2005).

Handoko, T. Hani, Manajemen, (Yogyakarta: BPFE, 2013).

Prayitno dkk., Pembelajaran Melalui Pelayanan BK di Satuan Pendidikan (Padang: UNP Press, 2014).

Prayitno, Seri Panduan Layanan dan Kegiatan Pendukung Konseling, (Padang: FIP UNP, 2012).

-----, Konseling Pancawaskita, (Padang: IKIP Press, 1988).

------, Konseling Integritas, (Padang: UNP Press, 2014).

Putra Nusa, Metode Penelitian Kualitatif Manajemen, (Jakarta: Raja Grafindo Persada, 2013).

Ranupandojo, Heidjrachman, Teori dan Konsep Manajemen, (Yogyakarta: UPP AMP YKPN, 1996).

Sugiyono, Metode Penelitian Bisnis, (Bandung: Alfabeta, 2007).

------, Memahami Penelitian Kualitatif, (Bandung: Alfabeta, 2008).

------, Statistika Untuk Penelitian, (Bandung: Alfabeta, 2008).

Tim Dosen UPI, Manajemen Pendidikan, (Bandung: Alfabeta, 2012).

Tim Balitbang Depdiknas, Metode Penelitian Pengembangan, (Jakarta: Balitbang Depdiknas, 2008).

Undang-undang Sistem Pendidikan Nomor 20 Tahun 2003.

Usman, Husaini, Manajemen Teori Praktek dan Riset Pendidikan, (Jakarta: Bumi Aksara, 2008). 


\title{
Revolusi Gaya Belajar untuk Fungsi Otak
}

\author{
M. Edy Waluyo \\ STAIN Syekh Abdurrahman Siddik Bangka Belitung \\ Email: m.edywaluyo@gmail.com
}

\begin{abstract}
This paper elaborate on an attempt to maximize the function of brain as a form of learning revolution. Learn properly is not an issue of whether or not a student pass the test. The meaning of learn is broader than a success of passing the exams. This is certainly related to the fun learning during the process of maximizing the ability to achieve success. Each student has a different learning styles depending on his/her character. There are four different models of learning that has been known today, ie sketch, sound, tactics, and movement. Students who have studied the model using the sketch tends to be easier to understand the information that they see. While those who have learned how to use the sound tends to be easier to capture verbal information from the teacher. Students who have a tendency to learn with tactics models require a touch of emotion. The kinesthetic learning models require movement in the learning process so that children learn more successfully.
\end{abstract}

Keyword: learning, model of learning, successful learning

\begin{abstract}
Abstrak
Tulisan ini menguraikan upaya memaksimalkan kerja sebagai bentuk revolusi belajar. Belajar dengan benar bukan permasalahan tentang lulus atau tidaknya seorang siswa dalam ujian. Makna belajar lebih luas daripada sekedar dapat lulus ujian. Hal ini tentu berhubungan dengan pembelajaran yang menyenangkan selama proses memaksimalkan kemampuan untuk meraih kesuksesan. Setiap siswa mempunyai cara belajar yang berbeda-beda tergantung karakter masingmasing siswa. Ada empat macam model belajar yang telah dikenal saat ini, yaitu gambar, suara, taktik, dan gerakan. Siswa yang mempunyai model belajar menggunakan gambar cenderung akan mudah memahami informasi yang telah dilihat. Sementara mereka yang mempunyai cara belajar menggunakan suara cenderung akan mudah menangkap informasi verbal dari guru. Siswa yang mempunyai kecenderungan belajar dengan model taktik memerlukan sentuhan emosi. Adapun model belajar kinestetik menuntut gerakan dalam proses pembelajaran sehingga belajar anak lebih berhasil.
\end{abstract}

Kata kunci: pembelajaran, pola pembelajaran, pembelajaran sukses 


\section{A. Pendahuluan}

Banyak pelajar maupun mahasiswa yang sering salah memahami makna belajar. Belajar diartikan sekedar membaca dan mengerjakan tugas-tugas dari guru atau dosen. Oleh karena itu, tidak sedikit yang mengalami kejenuhan dalam belajar. Bahkan, enggan untuk belajar atau malah takut belajar. Dalam pengertian berikut, belajar menjadi berat karena dianggap sebagai beban, bukan bagian dari proses memahami dan mencintai materi pelajaran.

Pada dasarnya, belajar bukan diartikan bagaimana seorang siswa dapat mengerjakan ujian, tetapi sejauh mana hati siswa terpaut pada pelajarannya. Dalam arti lain, mereka hanya belajar untuk menghadapi ujian atau menjadi pembelajaran sepanjang hidup. Belajar menurut Sumadi Suryabrata seperti mendapatkan perbendaharaan kata-kata baru, menghafal syair, menghafal nyanyian dan lain-lain. ${ }^{1}$

Betapa banyak anak yang ketika diperintah orang tuanya untuk belajar, kemudian sang anak masuk kamar, bahkan mengunci pintu kamarnya. Tetapi apa yang terjadi di dalam kamar? Anak sekedar membolak-balikkan lembar demi lembar buku pelajarannya, menatap sekilas pelajaran-pelajaran yang sudah dilalui hari ini. Episode berikutnya adalah membuat gambar-gambar abstrak yang tidak jelas temanya, tetapi sekaligus mengungkapkan kebosanan belajar yang luar biasa.

Apalagi sehari-hari di sekolah dengan sistem belajar yang terasa begitu kaku dan linier. Tugas guru mengajar, siswa belajar. Guru menerangkan, siswa mendengarkan. Guru memberikan soal, siswa mengerjakan. Belajar haruslah serius dan terkesan tegang, miskin senyuman. Jika ada siswa yang banyak bertanya, guru menganggapnya sebagai siswa bawel, cerewet dan banyak omong. Intinya, suasana belajar menjadi semakin membosankan. Siswa terpenjara oleh sistem pendidikan yang ada, tetapi mereka tidak dapat berbuat apa-apa.

Berdasarkan fenomena tersebut muncul teori-teori baru tentang pembelajaran, di antaranya ialah Quantum Learning yang digagas oleh Dr. Georgi Lozanov yang bergelut pada persoalan suggestology atau suggestopedia. Prinsip dari eksperimen yang

1 Sumadi Suryabrata, Psikologi Pendidikan, (Jakarta: Raja Grafindo Persada, 2014), hlm. 230. 
dilakukannya adalah sugesti dapat mempengaruhi hasil belajar. Dan, setiap detail apa pun dapat memberikan sugesti yang positif maupun negatif. ${ }^{2}$ Dalam inner mind pelajar adalah bagaimana kegiatan belajar itu mampu menyugesti dirinya bahwa belajar ini sangat mudah, menyenangkan dan bermanfaat dalam jangka dekat, menengah ataupun panjang. Salah satu usaha penting yang dapat dilakukan untuk membangkitkan semangat belajar adalah mendesain pembelajaran dalam suasana yang menyenangkan. ${ }^{3}$ Pembelajaran yang menyenangkan berusaha untuk membangun konsepsi baru yakni belajar bukanlah sebagaimana yang selama ini dibayangkan.

\section{B. Karakter Gaya Belajar}

Setiap siswa memiliki karakter gaya belajar yang berbeda dengan siswa yang lain. Ada empat gaya belajar yang dikenal, yaitu visual, auditori, taktil dan kinestetik. Siswa yang memiliki kecenderungan gaya belajar visual, akan mudah memahami informasi terhadap apa yang ia lihat, baik dalam bentuk buku maupun gambar. Sementara mereka yang memiliki kecenderungan gaya belajar auditori, cukup baik menangkap informasi verbal dari guru. Begitu pula, siswa yang memiliki kecenderungan gaya belajar taktil, akan belajar melalui sentuhan yang sertai dengan keterlibatan emosionalnya, dan siswa yang memiliki kecenderungan gaya belajar kinestetik akan lebih menonjol daya serapnya dengan motoriknya.

Otak Albert Einstain memiliki volume yang sama dengan ratarata orang dewasa, yaitu $1,4 \mathrm{~kg}$, secara fisik tidak ada bedanya, baik sisi warna maupun bentuk. Setelah diteliti, ternyata jumlah sel neuronnya juga sama, yaitu satu triliun sel neuron. Sel-sel neuron ini kemudian diteliti lebih lanjut dan barulah ditemukan perbedaannya. Sel neuron Albert lebih banyak yang sudah terkoneksi dengan sel neuron lainnya. Sedangkan otak orang ratarata, sel neuronnya belum banyak yang terkoneksi. Tetapi lebih mengejutkan sekaligus menggembirakan adalah setelah dihitung dan diperkirakan, ternyata sel neuron otak Albert yang sudah terkoneksi tidak lebih dari 3\% dari keseluruhan jumlah sel neuron.

2 Muhammad Noer, Hypno Teaching For Success Learning, (Yogyakarta: Bintang Pustaka Abadi, 2010), hlm. 6-7.

3 Ngainun Naim, Menjadi Guru Inspiratif, (Yogyakarta: Pustaka Pelajar, 2009), hlm. 175. 
Pertanyaannya, kalau si genius Albert saja baru 3\% potensi otaknya yang digunakan, lalu berapa persen potensi otak kita?

Sebagai gambaran perbandingan, kita bisa mengambil data pada tahun 1997, ketika dunia terjadi booming internet, dalam tiga hari mampu membangun koneksi 200 juta di antara pengguna komputer di dunia. Sementara itu, otak kita mampu membuat jaringan 15 kali lebih besar, yakni satu detik sama dengan jaringan internet tiga hari. Maka, sangatlah wajar jika Gordon Dryden menyatakan, "You're the owner of the world's most powerful computer" (Anda adalah pemilik komputer paling hebat di dunia). ${ }^{4}$

Maka dari itu, rasa takut untuk memulai belajar adalah hal pertama kali yang harus dibuang jauh-jauh oleh pelajar maupun mahasiswa, itulah yang membuat jaringan otak kita berada pada "status quo", status di mana otak mapan dalam ketidaktahuan. Semakin banyak belajar, membaca, berdiskusi, mengamati dan menganalisa sesuatu, maka semakin banyak pula koneksi-koneksi sel neuron di otak kita. Sehingga secara sadar atau tidak, sebenarnya kita sudah bertambah pintar dari sebelumnya.

Menurut perkiraan ada sekitar 12 miliar neuron dalam Sistem Saraf Pusat (SSP). Tiga perempat dari neuron tersebut terletak dalam korteks serebri, tempat informasi ditransmisikan melalui sistem saraf. Proses ini, mencakup tidak hanya penentuan tentang respons-respons yang sesuai dan efektif, tetapi juga penyimpanan memori dan perkembangan dari motorik asosiatif dan pola pikir. ${ }^{5}$

Untuk dapat belajar dengan maksimal, seorang guru dan pebelajar seharusnya memahami gaya belajar, yaitu: gaya belajar visual (visual learner), gaya belajar auditif (auditory learner) dan gaya belajar kinestetik (tactual learner).

1. Gaya Belajar Visual (Visual Learner)

Visual learner adalah gaya belajar di mana gagasan, konsep, data dan informasi lainnya dikemas dalam bentuk gambar dan teknik. Siswa yang memiliki tipe belajar visual memiliki interest yang tinggi ketika diperlihatkan gambar, grafik, grafis organisatoris. Seperti jaring, peta konsep dan ide peta, plot, dan ilustrasi visual lainnya. Beberapa teknik yang

${ }^{4}$ Farida Yunita Sari dan Mukhlis, Hypno Learning; 1 Menit Bikin Gila Belajar dan Siap Jadi Juara, (Jakarta: Visimedia, 2011), hlm. 16 - 17.

5 Tutu April Ariani, Sistem Neuro behaviour, (Jakarta: Salemba Medika, 2012), hlm. 9. 
digunakan dalam belajar visual untuk meningkatkan keterampilan berpikir dan belajar, lebih mengedepankan peran penting mata sebagai penglihatan (visual). Pada gaya belajar tersebut dibutuhkan banyak model dan metode pembelajaran yang digunakan dengan menitikberatkan pada peragaan.

Media pembelajarannya adalah objek-objek yang berkaitan dengan pelajaran tersebut, atau dengan cara menunjukkan alat peraganya langsung pada siswa atau menggambarkannya di white board atau papan tulis. Bahasa tubuh dan ekspresi muka gurunya juga sangat penting peranannya untuk menyampaikan materi pelajaran. Mereka cenderung untuk duduk di depan agar dapat melihat dengan jelas. Mereka berpikir menggunakan gambar-gambar di otak dan belajar lebih cepat dengan menggunakan tampilantampilan visual. Seperti halnya diagram, buku pelajaran bergambar, CD interaktif, digital content dan video (MTV). Di dalam kelas anak visual lebih suka mencatat sampai detaildetailnya untuk mendapatkan informasi.

2. Gaya Belajar Auditif (Auditory Learner)

Auditory learner adalah suatu gaya belajar pada siswa yang belajar melalui mendengarkan. Siswa yang memiliki gaya belajar auditori akan mengandalkan kesuksesan dalam belajarnya melalui telinga (alat pendengarannya). Oleh karena itu, guru sebaiknya memperhatikan para siswa hingga ke alat pendengarannya. Anak yang mempunyai gaya belajar auditori dapat belajar lebih cepat dengan menggunakan diskusi verbal dan mendengarkan penjelasan apa yang dikatakan guru. Anak dengan gaya belajar auditori dapat mencermati makna yang disampaikan oleh guru melalui verbal simbol atau suara, tinggi rendahnya, kecepatan berbicara dan hal-hal auditori lainnya. Anak-anak seperti ini dapat menghafal lebih cepat melalui membaca teks dengan keras atau mendengarkan media audio.

\section{Gaya Belajar Kinestetik (Tactual Learner)}

Tactual learner adalah gaya siswa belajar dengan cara melakukan, menyentuh, merasa, bergerak dan mengalami. Anak yang mempunyai gaya belajar kinestetik mengandalkan belajar melalui bergerak, menyentuh dan melakukan tindakan. Anak seperti ini sulit untuk duduk diam berjam-jam, karena keinginan mereka untuk beraktivitas dan eksplorasi sangatlah 
kuat. Siswa yang bergaya belajar seperti ini belajarnya melalui gerak dan sentuhan. ${ }^{6}$ Oleh karena itu, pembelajaran yang dibutuhkan adalah pembelajaran yang bersifat kontekstual dan praktik.

\section{Hasil Belajar}

Mengenai hasil belajar, UNESCO menuangkannya dalam empat pilar pembelajaran yang meliputi:

1. Belajar Mengetahui (Learning to Know)

Belajar mengetahui berkenaan dengan perolehan, penguasaan, dan pemanfaatan informasi. Dewasa ini, terdapat ledakan informasi dan pengetahuan. Hal itu bukan saja disebabkan oleh adanya perkembangan yang sangat cepat dalam bidang ilmu dan teknologi. Akan tetapi, karena perkembangan teknologi yang sangat cepat, terutama dalam bidang elektronika, memungkinkan sejumlah besar informasi dan pengetahuan tersimpan, bisa diperoleh dan disebarkan secara cepat dan hampir menjangkau seluruh planet bumi. Belajar mengetahui merupakan kegiatan untuk memperoleh, memperdalam, dan memanfaatkan pengetahuan.

Pengetahuan diperoleh dengan berbagai upaya perolehan pengetahuan, seperti membaca, mengakses internet, bertanya, dan mengikuti kuliah. Pengetahuan dikuasai melalui hafalan, tanya jawab, diskusi, latihan pemecahan masalah dan penerapan. Pengetahuan dimanfaatkan untuk mencapai berbagai tujuan, memperluas wawasan, meningkatkan kemampuan, memecahkan masalah dan belajar lebih lanjut.

Ada beberapa hal yang merupakan landasan filosofis dari kegiatan belajar, yaitu:

a. Bagaimana siswa pertama-tama dan terutama harus "belajar bagaimana belajar"dan belajar bagaimana berfikir.

b. Belajar harus menyenangkan di samping membangun percaya diri.

${ }^{6}$ Rusman (dkk), Pembelajaran Berbasis Teknologi Informasi dan Komunikasi; Mengembangkan Profesionalitas Guru, (Jakarta: Raja Grafindo Persada, 2011), hlm. 33-34. 
c. Pengetahuan harus disampaikan dengan pendekatan multisensori dan multimodel dengan menggunakan berbagai bentuk kecerdasan.

d. Orang tua khususnya dan masyarakat umumnya harus terlibat sepenuhnya dalam pendidikan anak-anak.

e. Sekolah harus menjadi persiapan sebenarnya bagi dunia yang sebenarnya.

f. Prinsip-prinsip Manajemen Kualitas Total (MKT) dalam bisnis harus mengilhami dunia persekolahan. ${ }^{7}$

2. Belajar Berbuat atau Berkarya (Learning to Do)

Agar seseorang mampu menyesuaikan diri dan beradaptasi dalam masyarakat yang berkembang sangat cepat, maka seseorang perlu belajar berkarya. Belajar berkarya berhubungan erat dengan belajar mengetahui, sebab pengetahuan mendasari perbuatan. Dalam konsep komisi UNESCO, belajar berkarya ini mempunyai makna khusus, yaitu dalam kaitan dengan vokasional. Belajar berkarya adalah belajar atau berlatih menguasai keterampilan dan kompetensi kerja.

Seiring dengan tuntutan perkembangan industri dan perusahaan, maka keterampilan dan kompetisi kerja ini, juga berkembang semakin tinggi, tidak hanya pada tingkat keterampilan, kompetensi teknis atau operasional, tetapi sampai dengan kompetensi profesional. Karena tuntutan pekerjaan pada dunia industri dan perusahaan terus meningkat, maka individu yang akan memasuki dan/atau telah masuk di dunia industri dan perusahaan perlu terus berkarya. Mereka harus mampu doing much (berusaha berkarya banyak).

3. Belajar Hidup Bersama (Learning to Live Together)

Dalam kehidupan global, kita tidak hanya berinteraksi dengan beraneka kelompok etnik, daerah, budaya, ras, agama, dan profesi saja, tetapi hidup bersama dan bekerja sama dengan aneka kelompok tersebut. Agar mampu berinteraksi, berkomunikasi, bekerja sama dan hidup bersama antar kelompok dengan baik, maka dituntut belajar hidup bersama. Tiap kelompok memiliki latar belakang pendidikan, kebudayaan, tradisi, dan tahap perkembangan yang berbeda,

${ }^{7}$ Suryabrata, Psikologi Pendidikan ..., hlm. 328. 
agar bisa bekerja sama dan hidup rukun, mereka harus banyak belajar hidup bersama, being sociable (berusaha membina kehidupan bersama).

4. Belajar Menjadi Diri Sendiri yang Utuh (Learning to Be)

Tantangan kehidupan yang berkembang cepat dan sangat kompleks, menuntut pengembangan manusia secara utuh. Manusia yang seluruh aspek kepribadiannya berkembang secara optimal dan seimbang, baik aspek intelektual, emosi, sosial, fisik maupun moral. Dengan demikian, maka manusia dituntut banyak belajar mengembangkan seluruh aspek kepribadiannya. Sebenarnya tuntutan perkembangan kehidupan global, bukan hanya menuntut manusia berkembang secara menyeluruh dan utuh, namun manusia utuh yang unggul. Maka dari itu, mereka harus berusaha agar dapat mencapai banyak keunggulan (being excellence). ${ }^{8}$ Keunggulan diperkuat dengan moral yang kuat. Individuindividu global harus berupaya bermoral kuat atau being morally.

\section{Memahami Kerja Otak}

Lebih dari tiga dekade penelitian tentang belahan otak, adalah mungkin untuk menyimpulkan penemuan-penemuan tersebut ke dalam empat perbedaan pokok.

1. Belahan otak sebelah kiri mengontrol bagian tubuh sebelah kanan; belahan otak sebelah kanan mengontrol bagian tubuh sebelah kiri. Otak-otak kita itu kontralateral, maksudnya adalah masing-masing belahan otak mengontrol belahan tubuh lainnya yang bersebelahan. Itulah mengapa stroke pada bagian kiri otak seorang akan membuat sulit orang itu untuk menggerakkan bagian kanan tubuhnya, begitu pula sebaliknya. Sekitar 90 persen penduduk menggunakan tangan kanan, itu berarti bahwa dalam sekitar 90 persen penduduk, belahan otak kiri mengontrol gerakan-gerakan penting seperti tulisan tangan, makan, dan menggerakkan mouse komputer.

2. Belahan otak sebelah kiri bersifat berurutan; belahan otak sebelah kanan bersifat simultan. Belahan kiri pada khususnya bagus dalam mengenali peristiwa-peristiwa serial yakni peristiwa-peristiwa yang terjadi secara berurutan dan

\footnotetext{
${ }^{8}$ Rusman, Pembelajaran Berbasis Teknologi Informasi ..., hlm. 13-15.
} 
mengontrol urutan-urutan perilaku. Belahan kiri juga dilibatkan dalam mengontrol perilaku-perilaku serial. Fungsifungsi serial yang dilakukan oleh belahan kiri mencakup aktivitas-aktivitas verbal, seperti berbicara, memahami perkataan orang lain, membaca dan menulis. Dapat disimpulkan bahwa belahan otak kanan adalah gambar, sedangkan belahan kiri adalah ribuan kata-kata.

3. Belahan otak sebelah kiri mengkhususkan pada teks; belahan otak kanan pada konteks. Pada kebanyakan orang, bahasa bermula dalam belahan otak kiri. (Ini bisa berlaku bagi 95 persen pengguna tangan kanan dan 70 persen pengguna tangan kiri. Sisanya, sekitar 8 persen dari penduduk, dalam pembagian kerja bahasa lebih rumit). Akan tetapi, belahan otak kanan tidak menyerahkan tanggung jawab yang penuh kepada belahan otak kiri. Seharusnya dua sisi tersebut melakukan fungsi-fungsi yang saling melengkapi.

4. Hemat kata, belahan otak kiri memperhatikan apa yang dikatakan; belahan sebelah kanan memfokuskan pada bagaimana ia dikatakan - isyarat-isyarat nonverbal yang sering emosional yang disampaikan melalui pandangan, ekspresi wajah dan intonasi.

5. Belahan otak sebelah kiri menganalisa rincian-rincian; belahan otak sebelah kanan menyintesiskan keseluruhan perspektif tentang sesuatu. Secara umum, belahan sebelah kiri ikut serta dalam analisa informasi, sebaliknya belahan sebelah kanan dikhususkan pada perpaduan; ia pada khususnya bagus dalam mengumpulkan unsur-unsur yang terpisah untuk memahami sesuatu secara utuh. Analisa dan perpaduan mungkin dua cara menafsirkan informasi yang paling fundamental. ${ }^{9}$ yaitu:

Ada tiga tahap yang berlangsung dalam memori manusia,

1. Encoding merupakan proses pengodean terhadap apa yang dipersepsi dengan cara mengubahnya menjadi simbol-simbol atau gelombang-gelombang listrik tertentu, sesuai peringkat yang ada pada organisasi atau merupakan suatu proses

${ }^{9}$ Daniel H. Pink, Otak Kanan Manusia, (Yogyakarta: Think, 2010), hlm. 32-39. 
mengubah informasi ke dalam bentuk yang sesuai dengan sifat-sifat memori manusia.

2. Storage merupakan proses penyimpanan terhadap apa yang telah diproses dalam encoding. Storage bisa disebut retensi, yaitu proses pengendapan informasi yang diterima ke dalam suatu tempat tertentu.

3. Retrieval merupakan proses pemulihan kembali atau mengingat kembali apa yang telah disimpan sebelumnya. Proses mengingat kembali pada suatu proses mencari dan menemukan informasi yang disimpan dalam memori untuk digunakan kembali bila dibutuhkan. ${ }^{10}$

Sementara itu, berdasarkan lamanya kemampuan otak untuk menyimpan informasi, ada tiga jenis memori, yaitu memori sensoris, memori jangka pendek, dan memori jangka panjang.

1. Memori Sensoris. Memori sensoris mencatat apa yang kita lihat, dengar, raba, rasa dan bau. Dengan kata lain, memori sensoris mencatat hal-hal yang ada di dalam indra kita. Memori sensoris bersifat sangat singkat. Meskipun kita mentransfernya ke memori jangka pendek, data itu akan menghilang segera setelah apa yang kita rasakan berakhir. Sebagai contoh, ketika kita berjalan selama beberapa menit, kita melihat ratusan hal. Meskipun saat berjalan itu perhatian kita tertuju pada suatu hal yang kita lihat, maka akan segera terlupakan oleh sesuatu yang lain yang lebih menarik perhatian kita.

2. Memori Jangka Pendek. Memori jangka pendek berlangsung sedikit lebih lama. Selama kita menaruh perhatian pada sesuatu, kita dapat mengingatnya dalam memori jangka pendek. Misalnya, ketika kita terus-menerus mengulang sebuah nomor telepon sampai kita bisa menuliskannya, maka nomor tersebut akan tersimpan dalam memori kita selama kita aktif memikirkannya. Namun, jika kita berhenti memberi perhatian pada nomor itu, maka memori kita terhadap nomor itu akan terhapus dalam waktu $10-20$ detik. Dalam mengingat sesuatu berikutnya, otak akan mentransfernya ke memori jangka panjang. Dengan demikian, proses mengingat

10 Walgito dalam Agus Warseno dan Ratih Komorojati, Super Learning: Praktik Belajar-Mengajar yang Serba Efektif dan Mencerdaskan, (Yogyakarta: Diva Press, 2011), hlm. 22. 
nomor telepon ini pada dasarnya adalah suatu cara untuk memindahkan nomor dari memori jangka pendek ke memori jangka panjang.

3. Memori Jangka Panjang. Memori jangka panjang dapat menyimpan sejumlah informasi yang hampir tak terbatas. Memori jangka panjang berisi persepsi dan ide-ide yang berkisar dari beberapa menit hingga awal kehidupan masa lalu kita. Memori jangka panjang seperti hard disk besar dari sebuah komputer raksasa, di mana informasi tidak terbatas dapat disimpan seumur hidup. Dalam memori tersebut, kita mampu membangun ide-ide dan pengalaman, serta menunjukkan kembali informasi ketika kita membutuhkannya. ${ }^{11}$

Mencermati mekanisme kerja otak di atas, upaya-upaya berikut ini dapat diharapkan lebih meningkatkan kemampuan otak untuk merekam informasi, dalam hal ini berkaitan dengan bagaimana belajar dapat berjalan secara maksimal:

1. Buat sesuatu yang ingin dipelajari menjadi sesuatu yang menarik, atau paling tidak dicari sisi-sisi yang menarik. Sehingga kemampuan otak untuk mengingat lebih besar. Caranya dengan menggunakan indera untuk melihat lebih dalam dan intens, jika mungkin gunakan alat peraga untuk memicu sel-sel otak membuat koneksi yang lebih banyak. Jika tidak, imajinasikan obyek yang pada awalnya abstrak, dijadikan seolah-olah konkret, setelah itu berselancarlah dalam dunia ide untuk menemukan gelombang-gelombang ilmu pengetahuan.

2. Prinsip pengulangan. Sesuatu yang senantiasa diulang-ulang akan menjadi kebiasaan, dari kebiasaan itulah memori yang sudah terekam di otak sewaktu-waktu dapat dipanggil kembali. Pengulangan itu bukan hanya sekedar penyebutannya, tetapi dapat berupa peta konsep suatu mata pelajaran/mata kuliah yang ditempelkan di dinding kamar. Ketika intensitas mata membaca dan mencermati gambar dilakukan. Walaupun hanya sekilas, otak akan merespons dengan halus sehingga bangunan pengetahuan dapat terbangun kokoh.

11 Walgito dalam Warseno dan Komorojati, Super Learning ..., hlm. 24-27. 
3. Orang yang terbiasa menggunakan pikirannya untuk membangun suatu ide, atau berupaya untuk memecahkan masalah dengan mempertimbangkan sebab akibat atau berpandangan futuristik, biasanya memiliki keterampilan untuk berpikir secara sistematis. Dengan kemampuan berpikir seperti itu, bangunan ilmu pengetahuan yang telah tersusun bukan saja tertata rapi dalam folder pengetahuan dalam otaknya, tetapi sewaktu-waktu dibutuhkan dapat dipanggil dengan mudah. Ingat bahwa kemampuan memori jangka panjang seperti hard disk dengan kapasitas yang hampir tanpa batas.

Ada beberapa hal yang merupakan landasan filosofis dari kegiatan belajar, yaitu:

1. Bagaimana siswa pertama-tama dan terutama harus "belajar bagaimana belajar"dan belajar bagaimana berpikir.

2. Belajar harus menyenangkan di samping membangun percaya diri.

3. Pengetahuan harus disampaikan dengan pendekatan multisensori dan multimodel dengan menggunakan berbagai bentuk kecerdasan.

4. Orang tua khususnya dan masyarakat umumnya harus terlibat sepenuhnya dalam pendidikan anak-anak.

5. Sekolah harus menjadi persiapan sebenarnya bagi dunia yang sebenarnya.

6. Prinsip-prinsip Manajemen Kualitas Total (MKT) dalam bisnis harus mengilhami dunia persekolahan. ${ }^{12}$

Dalam hal ini ada empat konsep dasar yang ditawarkan oleh Colin Rose dan Malcom J. Nichols berkaitan dengan belajar, yaitu:

1. Belajar bagaimana belajar. Sistem pendidikan yang didasarkan pada prinsip-prinsip psikologis yang telah usang, tidak benar, dan terlalu menyederhanakan, juga sering berbenturan keras dengan keterampilan belajar alamiah yang dimiliki anak-anak, akan mengajarkan kepada mereka untuk tidak percaya dan menekan keterampilan mereka dalam belajar. Selain itu, akan menggerakkan anak-anak secara sistematis belajar untuk tidak belajar;

${ }^{12}$ Suryabrata, Psikologi Pendidikan ..., hlm. 328. 
2. Belajar bisa menyenangkan. Semakin menggembirakan dalam belajar, semakin banyak yang akan dapat diserap. Jika siswa dibawa oleh pendidikan institusional ke dalam suasana belajar yang tidak menyenangkan, maka betapa keras guru harus bekerja untuk meyakinkan para siswa bahwa belajar merupakan kegiatan yang menarik, bahkan menyenangkan.

3. Belajar dengan semua kecerdasan. Sebagian siswa membutuhkan penggambaran visual dan fisik dari konsepkonsep yang diajarkan. Sebagian yang lainnya lebih suka kerja otak yang abstrak. Sebagian lainnya lagi perlu gagasangagasan yang diungkapkan secara verbal dengan cara-cara yang berbeda. Sebagian lagi memetik keuntungan dari penjelasan bahan-bahan belajar oleh teman-temannya. Sebagian pelajar yang lainnya belajarnya lebih baik jika diberi kesempatan bermain sejenak dengan bahan-bahan yang akan dipelajarinya, seperti yang dilakukan di lab sains sebelum mereka menemukan informasi kuncinya. Dan siswa yang lain lebih suka jika diberikan jawaban secara langsung.

4. Belajar dengan kekuatan orang tua. Raymond J. Wlodkowski dan Judith H. Jaynes menyatakan, "Orang tua agaknya merupakan faktor yang paling berpengaruh atas motivasi anak dalam belajar. Pengaruh formatif mereka atas motivasi belajar anak-anaknya mempunyai pengaruh pada setiap tahap perkembangan yang berlangsung sepanjang periode masa sekolah lanjutan atas dan di luar itu." 13

Lebih lanjut keterkaitan antara lingkungan dan seluruh elemen gaya belajar teknologis dapat dilihat pada skema berikut:

${ }^{13}$ Collin Rose dan Malcolm J, Nichols, Accelerated Learning for The 21th Century; Cara Belajar Cepat Abad XXI. (Jakarta: Nuansa, 2003), hlm. 328-321. 


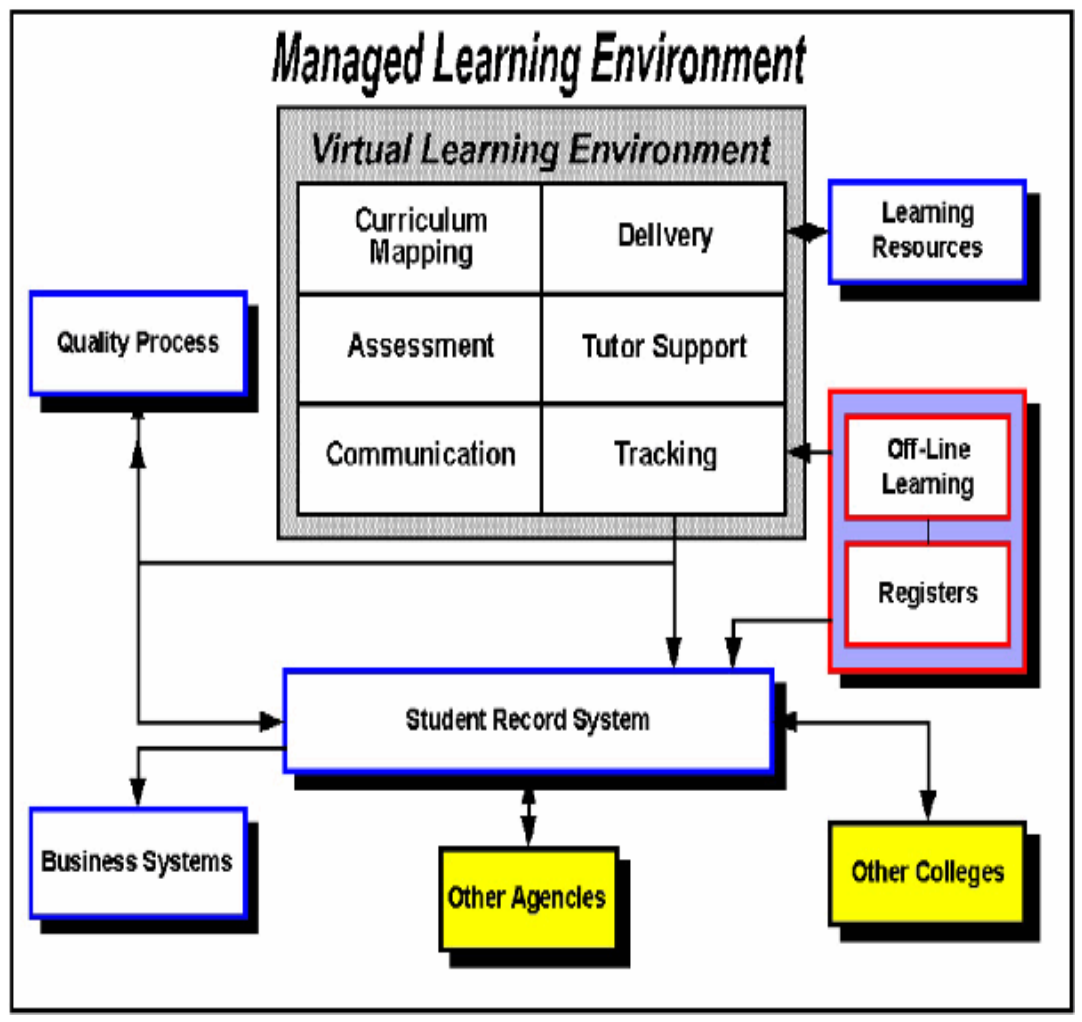

Sumber: http: \\www.finntrack.com 2010

Teknik belajar mnemonik (mnemonic technique) adalah sebuah teknik yang dapat membantu pelajar mengelola memori jangka panjangnya dengan baik, biasanya dilakukan dengan menggunakan singkatan atau kalimat yang mudah diingat. Contoh penggunaan teknik belajar mnemonik adalah sebagai berikut:

1. Untuk mengingat warna pelangi dalam bahasa Inggris, kalimat "Richard of York Gave Battle in Vain", setiap inisial yang disebutkan merujuk pada warna-warna pelangi (Red, Orange, Yellow, Green, Blue, Indigo, Violet).

2. Untuk mengingat danau besar di Amerika menggunakan akronim Homes, sesuai dengan huruf awal lima danau tersebut: Huron, Ontario, Michigan, Erie dan Superior. ${ }^{14}$

${ }^{14}$ Wikipedia The Free Encylopedia, Mnemonic, en.wikipedia.org/wiki/ Mnemonic, diakses tanggal 08 Januari 2015. 
Teknik belajar yang diperkenalkan oleh Tony Buzan pada tahun 1974, seorang ahli pengembangan potensi manusia dari Inggris mengungkapkan metode untuk memaksimalkan potensi pikiran manusia dengan menggunakan otak kanan dan kirinya secara simultan. Beberapa kata kunci yang menjadi fondasi dasar mind mapping adalah sebagai berikut:

1. Mulai dari tengah dengan gambar tema, gunakan minimal 3 warna.

2. Gunakan gambar, simbol, kode dan dimensi di seluruh peta pikiran yang dibuat.

3. Pilih kata kunci dan tulis dengan huruf besar atau kecil.

4. Tiap kata/gambar harus sendiri dan mempunyai garis sendiri.

5. Garis-garis itu saling dikaitkan, mulai dari tengah yaitu gambar Tema Utama. Garis bagian tengah tebal, organis, dan mengalir dari pusat keluar, menjulur seperti akar, atau pancaran cahaya.

6. Buat garis sama panjangnya dengan gambar/kata.

7. Gunakan warna dan kode rahasia sendiri di peta pikiran yang dibuat.

8. Kembangkan gaya penuturan, penekanan tertentu, dan penampilan khas di peta pikiran yang dibuat. Peta pikiran setiap orang tidak harus sama meskipun tema yang dibahas sama.

9. Gunakan kaidah asosiasi di peta pikiran yang dibuat.

10. Biarkan peta pikiran itu jelas, menggunakan hierarki yang runtut, urutan yang jelas dengan jangkauan sampai ke cabangcabang paling ujung. ${ }^{15}$

15 Wikipedia Ensiklopedia Bebas, Pemetaan Pikiran; id.wikipedia/ wiki/Pemetaan_pikiran, diakses 19 Juli 2012. 


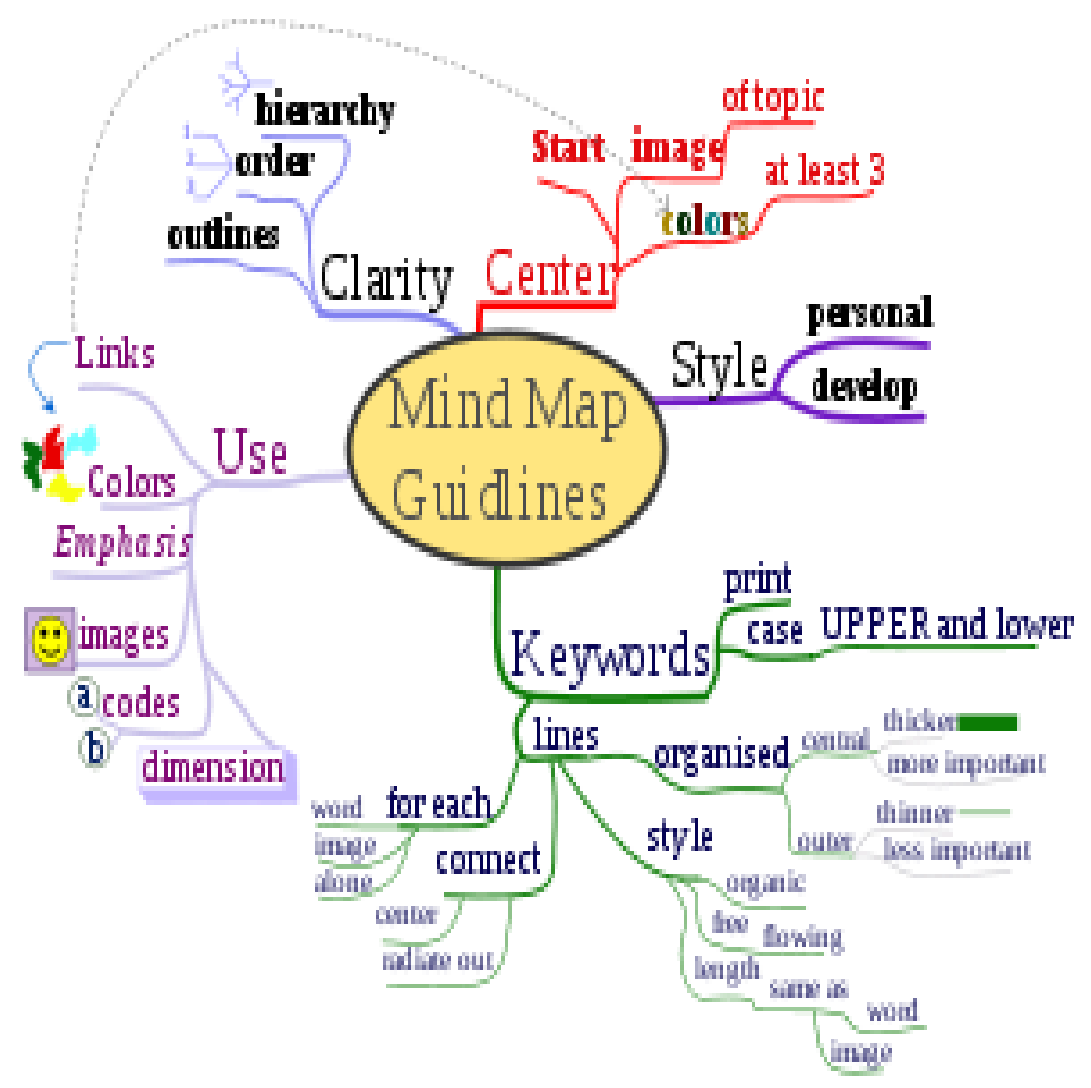

Untuk menjadi pembelajar yang unggul, kiranya perlu memperhatikan lima pilar, yaitu: rasa ingin tahu, optimisme, keikhlasan, konsistensi, dan pandangan visioner. ${ }^{16}$ Tidak dapat dipungkiri, Lingkungan belajar merupakan salah satu faktor yang memberikan kontribusi positif terhadap keberhasilan belajar. Masyarakat yang terkondisikan dengan jam wajib belajar, bukan saja menimbulkan suasana belajar yang kondusif, akan tetapi memberikan kesan tersendiri bagi siswa yang berada dalam lingkungan tersebut. Lingkungan belajar dapat berupa lingkungan virtual, di mana masing-masing memfasilitasi tercapainya suasana belajar yang kondusif.

${ }^{16}$ James Petras dalam Musthofa Rembangy, Pendidikan Transformatif; Pergulatan Kritis Merumuskan Pendidikan di Tengah Pusaran Arus Globalisasi,(Yogyakarta: Teras, 2010), hlm. 138-139. 


\section{E. Penutup}

Pemahaman terhadap konsep belajar memang sangat beragam. Bahkan sebagian para siswa memaknai belajar merupakan sesuatu yang sukar, kaku dan monoton (linier). Hal ini disebabkan karena pemahaman mereka terhadap konsep belajar, hanya sebatas fenomena saja. Artinya, belajar divisualisasikan seperti guru mengajar, siswa mengajar atau soal-soal dan buku-buku. Sehingga muncul stigma bahwa belajar membosankan.

Padahal perlu diketahui, otak manusia pada dasarnya memiliki cakupan memori yang luas. Albert Einstein misalnya, ternyata sel saraf pada otaknya yang digunakan hanyalah $3 \%$ dari potensi otaknya. Itu saja, ia dikenal sebagai 'orang genius'. Maka dari itu, otak kita sangat luar biasa dan kita perlu bangkit terhadap keterpurukan tersebut, yang menimbulkan ketidaktahuan.

Oleh sebab itu, dalam tulisan ini dipaparkan berbagai hal terkait fungsi otak yang tidak dimanfaatkan secara optimal. Sehingga perlu adanya revolusi gaya belajar seseorang, karena fungsi otak yang sangat luar biasa mau dioptimalkan secara maksimal.

Dari tulisan di atas, untuk melakukan sebuah revolusi gaya belajar dapatlah disarikan beberapa hal:

1. Mencari sisi-sisi menarik dari sebuah proses belajar, sehingga menemukan sugesti positif sehingga belajar menjadi sebuah kegiatan yang menyenangkan.

2. Menemukan gaya belajar kita dan memaksimalkannya sesuai dengan karakteristik masing-masing gaya belajar, atau belajar dengan semua potensi kecerdasan yang dimiliki.

3. Mencari tahu bagaimana kita dapat belajar dengan baik.

4. Belajar mengingat dengan teknik mnemonik.

5. Untuk memahami unit-unit pelajaran dapat dirangkum dengan teknik mind map.

\section{Kepustakaan}

Ariani,Tutu April, Sistem Neuro Behaviour, (Jakarta: Salemba Medika, 2012).

Naim, Ngainun, Menjadi Guru Inspiratif, (Yogyakarta: Pustaka Pelajar, 2009). 
Noer, Muhammad, Hypno Teaching for Success Learning, (Yogyakarta: Bintang Pustaka Abadi, 2010).

Pink, Daniel H., Otak Kanan Manusia, (Yogyakarta: Think, 2010).

Rembangy, Musthofa, Pendidikan Transformatif: Pergulatan Kritis Merumuskan Pendidikan di Tengah Pusaran Arus Globalisasi, (Yogyakarta: Teras, 2010).

Rose, Colin dan Malcolm J. Nicholl, Cara Belajar Cepat Abad XXI, (Jakarta: Nuansa, 2003).

Rusman (dkk), Pembelajaran Berbasis Teknologi Informasi dan Komunikasi: Mengembangkan Profesionalitas Guru, (Jakarta: Raja Grafindo Persada, 2011).

Sari, Farida Yunita dan Mukhlis, Hypno Learning: 1 Menit Bikin Gila Belajar dan Siap Jadi Juara, (Jakarta: Visimedia, 2011).

Suryabrata, Sumadi, Psikologi Pendidikan, (Jakarta: Raja Grafindo Persada, 2014).

Agus Warseno dan Ratih Komorojati, Super Learning: Praktik Belajar-Mengajar yang Serba Efektif dan Mencerdaskan, (Yogyakarta: Diva Press, 2011).

Wikipedia The Free Encylopedia. Mnemonic. en.wikipedia.org/wiki/Mnemonic. diakses tanggal 08 Januari 2015. 


\title{
Integrasi Pendidikan Anti Narkoba dalam Pendidikan Agama Islam dan Budi Pekerti Kurikulum 2013
}

\author{
Imam Machali \\ UIN Sunan Kalijaga Yogyakarta \\ E-mail: imam.machali@uin-suka.ac.id
}

\begin{abstract}
This article describe the antidrug education and the integration of anti-drug education in the curriculum of Islamic religious and moral education of the year 2013. The results showed that the antidrug education began in elementary, junior and senior high school that includes knowledge about drugs and the dangers, increase self-esteem, and the formation of assertiveness. Integration of anti-drug education in the curriculum of Islamic religious education and moral includes three aspects, namely: knowledge (cognitive), attitudes and behaviours (affective), and skills (psychomotor). Implementation of antidrug education at school level using integrative-inclusive strategy. Anti-drug education learning management can be integrated in all subjects, both religious and secular.
\end{abstract}

Keyword: antidrug education, curriculum 2013

\begin{abstract}
Abstrak
Artikel ini bertujuan mendeskripsikan pendidikan anti narkoba dan integrasi pendidikan anti narkoba pada kurikulum Pendidikan Agama Islam dan Budi Pekerti Tahun 2013. Hasil penelitian menunjukkan bahwa pendidikan antinarkoba sudah dimulai sejak SD, SMP dan SMA yang mencakup pengetahuan tentang narkoba dan bahayanya, peningkatan harga diri, dan pembentukan asertasi. Integrasi pendidikan anti narkoba pada kurikulum Pendidikan Agama Islam dan Budi Pekerti mencakup tiga domain, yakni domain pengetahuan (kognitif), sikap dan perilaku (afeksi), dan keterampilan (psikomotorik). Implementasi pendidikan antinarkoba di jenjang sekolah menggunakan strategi integratif-inklusif. Manajemen pembelajaran pendidikan antinarkoba dapat diintegrasikan di semua mata pelajaran, baik agama maupun umum.
\end{abstract}

Kata kunci: pendidikan antinarkoba, kurikulum 2013 


\section{A. Pendahuluan}

Ancaman bahaya penyalahgunaan narkoba semakin meningkat. Sasarannya adalah generasi muda yang merupakan tulang punggung pembangunan bangsa. Berdasarkan hasil survei Badan Narkotika Nasional (BNN) diperoleh data bahwa rata-rata usia pertama kali menggunakan narkoba terjadi pada usia 12-15 tahun. Hasil penelitian BNN bekerja sama dengan Pusat Studi Kesehatan Universitas Indonesia menunjukkan bahwa pada tahun 2008 angka prevalensi penyalahgunaan narkoba mencapai 1,99 persen atau setara dengan 3,6 juta jiwa sedangkan pada 2011 mengalami peningkatan menjadi 2,2 persen atau setara dengan 4,2 juta jiwa.

Penyalahgunaan narkotika di Indonesia dari tahun ke tahun terus menunjukkan peningkatan yang signifikan. Berdasarkan data hasil riset BNN dengan Universitas Indonesia, angka itu mencapai 2,32 persen sepanjang tahun 2012. Angka itu diperkirakan akan meningkat menjadi 2,8 persen pada tahun 2015 jika terus dibiarkan. "Diperkirakan angka prevalensi itu di tahun 2015 menjadi 2,8 persen atau setara dengan 5 juta jiwa orang Indonesia. ${ }^{1}$. Dugaan penyalahgunaan narkoba diprediksi sebesar 5,6 juta jiwa. Sedangkan dampak kematian atas penyalahgunaan narkoba sebesar 50 orang per hari. Tersangka kasus narkoba pada rentang tahun 2010 sampai dengan tahun 2014 sebanyak 134.117 orang. ${ }^{2}$

Salah satu langkah yang efektif dalam mengerem laju penyalahgunaan narkoba adalah dengan pendidikan. Pada Tahun 2013, pemerintah memasukkan pendidikan anti narkoba dalam materi pembelajaran di kurikulum 2013. Pendidikan anti narkoba dimasukkan dalam pendidikan ekstrakurikuler. Dimasukkannya pendidikan anti narkoba dalam kurikulum dimaksudkan untuk mengantisipasi penyalahgunaan narkoba sejak dini.

Keputusan pemerintah memasukkan pendidikan anti narkoba merupakan respons atas berbagai kritik terhadap dunia pendidikan selama ini. Pendidikan dianggap tidak mampu melahirkan lulusan yang berkualitas; manusia Indonesia seutuhnya seperti cita-cita luhur bangsa dan yang diamanatkan oleh Undang-undang Pendidikan. Permasalahan kegagalan dunia pendidikan di

\footnotetext{
${ }^{1}$ Suara Karya, Jum'at 12 April 2013

${ }^{2}$ Jawa Post, Minggu 8 Februari 2015
} 
Indonesia — termasuk pendidikan agama - disebabkan dunia pendidikan selama ini hanya membina kecerdasan intelektual, wawasan dan keterampilan semata, tanpa diimbangi dengan pembinaan kecerdasan emosional.

Kurikulum 2013 bertema "Insan Indonesia yang Produktif, Kreatif, Inovatif dan Afektif", dirancang untuk mengintegrasikan ilmu pengetahuan yang dimiliki peserta didik dalam sikap, perilaku dan mental spiritual kehidupan yang diimplementasikan dalam keterampilan (skill) peserta didik. Lebih-lebih bagi pendidikan agama Islam sebagai imbas dari pola pendidikan selama ini yang dipandang lebih mengutamakan kemampuan berpikir (kognitif) daripada afektif dan psikomotor peserta didik.

Dalam Kurikulum 2013 terjadi perubahan istilah Standar Kompetensi (SK) setiap aspek dalam PAI (Al-Qur'an, Aqidah, Akhlaq, Fiqih, SKI) menjadi Kempetensi Inti (KI), yaitu Sikap Spiritual (KI 1), Sikap Sosial (Afektif [KI 2]), Pengetahuan (Kognitif [KI 3]), dan Keterampilan (Psikomotorik [KI 4]).

Perubahan ini merupakan harapan mulia dari pemerintah yang menginginkan PAI tidak hanya memuat teori-teori, akan tapi mendorong siswa agar memiliki keterampilan (skill) dan juga berakhlak mulia. Hal ini terlihat dari adanya penambahan kata "Budi Pekerti" dalam nama mata pelajaran PAI, yang walaupun tanpa penambahan kata tersebut juga sebenarnya Agama Islam sudah menjelaskan dan mengajarkan bagaimana setiap orang berbudi pekerti atau berakhlak mulia karimah.

Secara hierarkis, Standar Isi Kurikulum PAI 2013 dijabarkan dalam bentuk Kompetensi Inti (KI) dan Kompetensi Dasar (KD) serta Tujuan Pembelajaran yang terdiri dari empat kompetensi utama yaitu: Kompetensi Inti Satu/ KI-1 (Sikap Spiritual): Menghargai dan menghayati ajaran agama yang dianutnya, Kompetensi Inti dua/KI-2 (Sikap Sosial): Menghargai dan menghayati perilaku jujur, disiplin, tanggung jawab, peduli (toleransi, gotong royong), santun, percaya diri dalam berinteraksi secara efektif dengan lingkungan sosial dan alam dalam jangkauan pergaulan dan keberadaannya. Kompetensi Inti Tiga/KI-3 (Pengetahuan): Memahami pengetahuan (faktual, konseptual dan prosedural) berdasarkan rasa ingin tahunya tentang ilmu pengetahuan, teknologi, seni, budaya terkait fenomena dan kejadian tampak mata. Kompetensi Inti Empat/KI-4 (Keterampilan): Mencoba, mengolah, dan menyaji dalam ranah 
konkret (menggunakan, mengurai, merangkai, memodifikasi, dan membuat) dan ranah abstrak (menulis, membaca, menghitung, menggambar, dan mengarang) sesuai dengan yang dipelajari di sekolah dan sumber lain yang sama dalam sudut pandang/teori yang kemudian dijabarkan ke dalam Kompetensi Dasar (KD). ${ }^{3}$

Artikel ini bertujuan mendeskripsikan integrasi pendidikan anti narkoba dalam kurikulum 2013 mata pelajaran Pendidikan Agama Islam dan Budi Pekerti. Degan menggunakan analisis isi (content analysis) pertanyaan yang akan dijawab dalam artikel ini adalah bagaimana materi pendidikan anti narkoba dan integrasi pendidikan anti narkoba pada kurikulum Pendidikan Agama Islam dan Budi Pekerti Tahun 2013.

\section{B. Pendidikan Antinarkoba}

Narkoba adalah singkatan dari narkotika dan obat/bahan berbahaya. Selain narkoba, istilah lain yang diperkenalkan khususnya oleh Departemen Kesehatan Republik Indonesia adalah Napza yang merupakan singkatan dari dari Narkotika, Psikotropika dan Zat Adiktif. Sedangkan pendidikan Antinarkoba adalah usaha sadar dan terencana untuk mewujudkan suasana belajar dan proses pembelajaran agar peserta didik secara aktif mengembangkan potensi dirinya untuk memiliki kekuatan spiritual keagamaan, pengendalian diri, menghindari, menolak, melawan, dan mengampanyekan anti narkoba sehingga bahaya narkoba tidak meluas ke segenap masyarakat.

Pendidikan Antinarkoba dilakukan secara terpadu dengan melibatkan setiap unsur masyarakat yang terkait dan peduli terhadap usaha preventif bahaya narkoba. Terdapat tiga prinsip yang melandasi Pendidikan Antinarkoba. Pertama, terpadu yaitu kerja sama erat antara pihak sekolah dengan masyarakat. Tujuannya agar semua pihak memahami akan bahaya narkoba dan memperkuat tekad agar orang yang belum terkena jangan sampai tertular oleh kecanduan narkoba. Kedua profesional artinya harus disusun progarm-program Pendidikan Antinarkoba yang sistematis dan sesuai perkembangan peserta didik. Ketiga, kebutuhan artinya program Pendidikan Antinarkoba hendaknya berdasarkan kebutuhan masyarakat, terutama generasi muda dan keluarga.

${ }^{3}$ Kemendikbud, Kurikulum 2013, (Jakarta: Kementerian Pendidikan dan Kebudayaan RI, 2013). 
Sekolah memegang peranan penting dalam penanggulangan narkoba, karena sekolah merupakan tempat berkumpulnya anakanak muda yang sering dijadikan sasaran narkoba. Data Bareskrim Mabes Polri menyebutkan tersangka penyalah guna narkoba di lingkungan SD tahun 2003 berjumlah 88 orang dan meningkat tahun 2004 menjadi 407 orang. Di lingkungan SMP tahun 2003 berjumlah 632 orang dan tahun 2004 meningkat 968 orang, dan di lingkungan SMA tahun 2003 berjumlah 887 orang dan tahun 2004 meningkat berjumlah menjadi 1511 orang.

Sekolah sebagai institusi dan lembaga pendidikan memiliki empat komponen penting. Pertama, sekolah menyediakan kerangka kerja bagi perencanaan, pengimplementasian dan pengevaluasian dalam upaya pencegahan dan pengurangan penyalahgunaan drug (termasuk alkohol dan rokok). Kedua, sekolah menyediakan lingkungan fisik dan sosial bagi pengembangan kesehatan siswa berkaitan dengan tujuan pendidikan yang ingin dicapai sesuai dengan jenjang pendidikan. Ketiga, membantu siswa berperilaku (skills-based drug education) dan menciptakan kondisi yang sehat bagi siswa. Keempat, Sekolah berperan dalam membentuk pengetahuan, sikap dan keterampilan yang diperlukan remaja nantinya dalam memilih dan mengambil keputusan untuk tidak menggunakan drug.

Salah satu indikasi suatu sekolah telah tumbuh religiositas peserta didiknya antara lain adalah terdapatnya perilaku dan tindakan yang mencerminkan pada anti narkoba. Sebab anti narkoba adalah keyakinan yang membuat seseorang bertindak atas dasar. Sedangkan Djahiri mendefinisikan anti narkoba sebagai harga yang diberikan oleh seseorang atau sekelompok orang terhadap sesuatu (material-immaterial, personal, kondisional) atau harga yang dibawakan/tersirat atau menjadi jati diri dari sesuatu.

Pencegahan berbasis sekolah (school based prevention) lebih mudah dilaksanakan karena sekolah terstruktur sehingga dapat diadakan pengawasan secara komprehensif dan terpadu. Pelaksanaan pendidikan pencegahan di sekolah dimasukkan dalam kegiatan ekstrakurikuler dan pengembangan diri ataupun disisipkan pada pelajaran agama dan budi pekerti yang bertujuan untuk mensosialisasikan kebijakan penanggulangan dan bahaya penyalahgunaan narkoba. Dalam mengimplementasikan konsep integrasi pendidikan anti narkoba dalam pembelajaran di sekolah, kita dapat merujuk referensi yang ditawarkan Bagir, dkk. yang 
membaginya ke dalam empat tataran implementasi, yaitu tataran konseptual, institusional, operasional, dan arsitektural. Dalam tataran konseptual, integrasi pendidikan anti narkoba dapat diwujudkan melalui perumusan visi, misi, tujuan dan program sekolah (rencana strategis sekolah).

Adapun secara institusional, integrasi dapat diwujudkan melalui pembentukan institution culture yang mencerminkan paduan antara anti narkoba dan pembelajaran. Dalam tataran operasional, rancangan kurikulum dan esktrakurikuler harus diramu sedemikian rupa sehingga nilai-nilai fundamental agama dan ilmu terpadu secara koheren. Sementara secara arsitektural, integrasi dapat diwujudkan melalui pembentukan lingkungan fisik yang berbasis IPTEK (Ilmu Pengetahuan dan Teknologi) dan IMTAK (Iman dan Takwa). Seperti, sarana ibadah yang lengkap, sarana laboratorium yang memadai, serta perpustakaan yang menyediakan buku-buku agama dan ilmu umum secara lengkap.

\section{Kurikulum PAI dan Budi Pekerti $2013^{4}$}

Istilah kurikulum mempunyai pengertian yang cukup beragam mulai dari pengertian yang sempit hingga yang sangat luas. Pengertian kurikulum secara sempit seperti yang dikemukakan oleh William B. Ragan yang dikutip oleh Hendyat Soetopo dan Wasty Soemanto: "Traditionally, the curriculum has meant the Subject taugth in school, or course of study". ${ }^{5}$ Senada dengan definisi ini, Carter V. Good menyatakan: "Curriculum as a systematic group of courses or sequences of subject required for graduation or certification in a major field of study, for example, social studies curriculum, physical education curriculum...". ${ }^{6}$ Ronald C. Doll mendefinisikan: "The curriculum of the school is the formal and informal content and process by which learner gain knowledge understanding develop skills and alter attitude

${ }^{4}$ Eksplorasi mengenai kurikulum ini diambilkan dari naskah penulis berjudul "Kebijakan Perubahan Kurikulum 2013 dalam Menyongsong Indonesia Emas Tahun 2045" dalam Jurnal Pendidikan Islam, (volume III, No 1/Juni 2014), hlm. 71-94.

5 Hendyat Soetopo dan Wasty Soemanto, Pembinaan dan Pengembangan Kurikulum, (Jakarta: Bina Aksara, 1986), hlm. 12.

${ }^{6}$ Carter V. Good, ed., Dictionary of Education, Third edition, (New York: McGraw-Hill, 1973), hlm. 157. 
appreciations and values under the auspice of that school". ${ }^{7}$ Beberapa pengertian kurikulum ini merupakan pengertian yang sempit dan tradisional. Di sini, kurikulum sekedar memuat dan dibatasi pada sejumlah mata pelajaran yang diberikan guru atau sekolah kepada peserta didik guna mendapatkan ijazah atau sertifikat.

Pengertian kurikulum yang sangat luas dikemukakan oleh Hollis L. Caswell dan Doak S. Campbell yang memandang kurikulum bukan sebagai sekelompok mata pelajaran, tetapi kurikulum merupakan semua pengalaman yang diharapkan dimiliki peserta didik di bawah bimbingan para guru "curriculum not as a group of courses but as all the experiences children have under the guidance of teachers". ${ }^{8}$ Sejalan dengan pengertian ini, J. Galen Saylor, William M. Alexander dan Arthur J. Lewis juga mengungkapkan pengertian kurikulum yang dikutip oleh Peter F. Oliva "We define curriculum as a plan for providing sets of learning opportunities for persons to be educated". 9

Demikian pula, disampaikan oleh Harold B, Albertycs yang memandang kurikulum sebagai all of the activities that are provided for students by the school. ${ }^{10}$ Selain itu, Alice Miel juga mengemukakan, yang dikutip Nasution bahwa kurikulum meliputi keadaan gedung, suasana sekolah, keinginan, keyakinan, pengetahuan dan sikap orang-orang yang melayani dan dilayani sekolah, yakni anak didik, masyarakat, para pendidik dan personalia - termasuk penjaga sekolah, pegawai administrasi, dan orang lainnya yang ada hubungannya dengan murid-murid. ${ }^{11}$

Pengertian kurikulum sebagaimana di atas mencakup semua pengalaman yang diharapkan dikuasai peserta didik di bawah bimbingan para guru. Pengalaman ini bisa bersifat intrakurikuler, kokurikuler maupun ekstra kurikuler, baik pengalaman di dalam maupun di luar kelas. Dengan demikian dapat dipahami bahwa kurikulum mencakup pengertian yang sangat luas meliputi apa

7 Ronald C. Doll, Curriculum Improvemet Decision Making And Process, (Boston: Nallyn Bacon, 1996), hlm. 15.

${ }^{8}$ Peter F. Oliva, Developing the Curriculum, (New York: HarperCollins Publisher, 1992), hlm. 6

${ }^{9}$ Peter F. Oliva, Developing the Curriculum..., hlm. 6 lihat juga S. Nasution, Pengembangan Kurikulum, (Bandung: Citra Aditya Bakti, 2003), hal. 4

${ }^{10}$ S. Nasution, Pengembangan Kurikulum,... hlm. 5

${ }^{11}$ S. Nasution, Pengembangan Kurikulum,... hlm. 6 
yang disebut dengan kurikulum potensial, kurikulum aktual, dan kurikulum tersembunyi atau hidden curriculum. Kurikulum tersembunyi adalah hal atau kegiatan yang terjadi di sekolah dan ikut mempengaruhi perkembangan peserta didik, namun tidak diprogramkan dalam kurikulum potensial. Dalam pengertian lain kurikulum tersembunyi adalah hasil; dari suatu proses pendidikan yang tidak direncanakan. Artinya, perilaku yang muncul dari luar tujuan yang dideskripsikan oleh guru. ${ }^{12}$

Terdapat tiga hal dalam pembahasan kurikulum dan pengembangannya yaitu pertama kurikulum sebagai rencana (as a plan) yang menjadi pedoman (guideline) dalam mencapai tujuan yang akan dicapai. Kedua, kurikulum sebagai materi atau isi (curriculum as a content) yang akan disampaikan kepada peserta didik, dan ketiga, dengan cara apa dan bagaimana kurikulum disampaikan. Ketiga hal tersebut adalah satu kesatuan dan bersinergi dalam rangka mencapai tujuan pendidikan yang diinginkan.

Oleh karena itu, pengembangan kurikulum dapat dipahami sebagai sebuah proses penyusunan rencana tentang isi atau materi pelajaran yang harus dipelajari dan bagaimana cara mempelajarinya. Dalam hal ini pengembangan kurikulum adalah sebuah proses yang terus menerus (continue), dinamis (dynamic), dan kontekstual (contextual). ${ }^{13}$

Kurikulum memiliki fungsi dan peran yang sangat penting dan strategis. Meskipun bukan satu-satunya faktor utama keberhasilan proses pendidikan, kurikulum menjadi petunjuk dan arah terhadap keberhasilan pendidikan. Kurikulum menjadi penuntun (guide) para pelaksana pendidikan (pendidik dan tenaga kependidikan) untuk mengembangkan kreativitas dan kemampuannya dalam mengembangkan dan menjabarkan berbagai materi dan perangkat pembelajaran. Oleh karena itu, pendidik dan tenaga kependidikan yang baik adalah yang mampu memahami kurikulum dan mengimplementasikannya pada proses pembelajaran.

Perubahan, pengembangan, dan perbaikan terus dilakukan, seiring dengan tuntutan dan perubahan zaman dalam berbagai

12 Wina Sanjaya, Kurikulum dan Pembelajaran. (Jakarta: Kencana, 2008), hlm. 25

${ }^{13}$ Imam Machali, "Kurikulum Dimensi Kecerdasan Majemuk (Multiple Intellegences) dalam Kurikulum 2013”, Insania, (Vol. 19 No. 1 Juni 2014), hlm. 5 
aspek kehidupan di era globalisasi. Pergulatan perubahan kurikulum sangat nampak pada tahun 1975, 1984, 1994, banyak menuai berbagai kritik karena dinilai terlalu banyak mata pelajaran dan terlalu padat materi. Padatnya kurikulum berdampak pada padatnya informasi dalam buku teks.

Pada tahun 1975, pembaruan kurikulum didasarkan pada perkembangan ilmu pengetahuan dan teknologi pada saat itu, sehingga pembaruan tersebut menghasilkan kurikulum 1975 yang sangat sarat beban dan sarat muatan, bahan-bahan yang berat dan sangat berorientasi pada sasaran hasil. Hal ini dipengaruhi oleh paradigma kerangka instruksional, yang sangat mendasarkan diri pada sasaran, instruksi dan evaluasi. Pembaharuan Kurikulum tahun 1984 berusaha menyederhanakan itu semua. Pembaruan tahun 1994 memadukan teknologi melalui pemecahan masalah, berpikir kritis, dan keterampilan bertanya dalam praktik di kelas. ${ }^{14}$

Koreksi, evaluasi dan kritik terhadap kurikulum 1994 terus dilakukan. Kemudian pemerintah melakukan pembaruan dengan diberlakukannya kurikulum 2004 yang diharapkan sebagai kurikulum yang menerapkan kompetensi sebagai tujuan akhir pembelajaran. Kurikulum 2004 kemudian dikenal dengan Competence Based Curriculum atau Kurikulum Berbasis Kompetensi (KBK). ${ }^{15}$ Belum lagi KBK diterapkan secara menyeluruh, muncul kemudian Kurikulum Tingkat Satuan Pendidikan (KTSP) yang

14 Direktorat Jenderal Pendidikan Islam, Direktorat Pendidikan Agama Islam, Pedoman Umum Implementasi Kurikulum 2013, (Jakarta; Kementerian Agama RI, 2013), hlm. 1

15 Kompetensi secara bahasa berasal dari kata "competence" yang berarti "kecakapan", "kemampuan", "keahlian". Spencer mendefinisikan kompetensi sebagai Competency is an underlying characteristic of an individual that is causally related to criterion-referenced effective and/or superior performance ion a job or situation. Tiga kata kunci dalam definisi tersebut yaitu underlying characteristic, causally related, dan criterionreferenced. Underlying characteristic means the competency is a fairly deep and enduring part of a person's personality and can predict behaviour in a wide variety of situations and job tasks. Causally related means that a competence causes or predicts behaviour and performance. Dan criterionreferenced means that competency actually predicts who does something well or poorly, as measured on a specific criterion or standard. Dalam sebuah kompetensi, menurut Spencer setidaknya mempunyai lima krakteristik yaitu motif, traits, konsep diri (self-concept), pengetahuan (knowledge) dan keterampilan (skill). Lihat Lyle M. Spencer, Competence at Work: Models for Superior Performance, (Canada: John wiley \& Son, 1993), hlm. 9 
merupakan penyempurnaan kurikulum KBK yang dianggap lebih mampu menjawab tantangan yang lebih jelas dan memberikan muatan lokal kepada daerah atau lembaga pendidikan.

Walaupun perubahan dan pembaruan kurikulum terus dilakukan dengan melibatkan berbagai unsur yang berkompeten, kritik dan berbagai keluhan terus diarahkan terhadap pemerintahKemendikbud - sebagai lembaga penanggung jawab bidang pendidikan nasional. KTSP dinilai masih memberatkan pada peserta didik, baik dari substansi maupun metodologinya. Pelajaran yang diterapkan di satuan pendidikan terutama di jenjang pendidikan dasar, terlalu padat dan tumpang tindih. Berdasarkan hasil kajian, penelitian, dan evaluasi menyeluruh kemudian KTSP disempurnakan dalam kurikulum baru yang dikenal dengan kurikulum 2013.

Dinamakan dengan kurikulum 2013, sebab kebijakan implementasi kurikulum ini dilaksanakan pada tahun 2013. Berbagai kebijakan pendukung implementasi kurikulum ini dikeluarkan pada tahun 2013 seperti PP Nomor 32 Tahun 2013 tentang Perubahan atas Peraturan Pemerintah Nomor 19 Tahun 2005 Tentang Standar Nasional Pendidikan, Permendikbud No 54 Tahun 2013 tentang SKL, 65 tahun 2013 tentang standar Proses, dan lain-lain. Bahkan pada tahun 2014 Kementerian Pendidikan dan Kebudayaan juga telah mengeluarkan peraturan pendukung, dan penyempurnaan implementasi kurikulum 2013 seperti Permendikbud Nomor 57, 58, 59 Tahun 2014 tentang Kurikulum 2013 SD/MI, SMP/MTs, SMA/MA, dan lain-lain.

Kehadiran kurikulum 2013 diharapkan mampu melengkapi kekurangan-kekurangan yang ada pada kurikulum sebelumnya. Kurikulum 2013 disusun dengan mengembangkan dan memperkuat sikap, pengetahuan, dan keterampilan secara berimbang. Penekanan pembelajaran diarahkan pada penguasaan pengetahuan dan keterampilan yang dapat mengembangkan sikap spiritual dan sosial sesuai dengan karakteristik Pendidikan Agama Islam dan Budi Pekerti diharapkan akan menumbuhkan budaya keagamaan (religious culture) di sekolah.

Titik tekan pengembangan Kurikulum 2013 ini adalah penyempurnaan pola pikir, penguatan tata kelola kurikulum, pendalaman dan perluasan materi, penguatan proses pembelajaran, dan penyesuaian beban belajar agar dapat menjamin kesesuaian antara apa yang diinginkan dengan apa yang dihasilkan. Oleh 
karena itu, implementasi Kurikulum 2013 diyakini sebagai langkah strategis dalam menyiapkan dan menghadapi tantangan globalisasi dan tuntutan masyarakat Indonesia masa depan.

Kompetensi masa depan yang diperlukan dalam menghadapi arus globalisasi antara lain berkaitan dengan kemampuan berkomunikasi, kemampuan berpikir jernih dan kritis, kemampuan mempertimbangkan segi moral suatu permasalahan, kemampuan menjadi warga Negara yang bertanggung jawab, kemampuan mencoba untuk mengerti dan toleran terhadap pandangan yang berbeda, dan kemampuan hidup dalam masyarakat yang mengglobal. Di samping itu, generasi Indonesia juga harus memiliki minat luas dalam kehidupan, memiliki kesiapan untuk bekerja, memiliki kecerdasan sesuai dengan bakat/minatnya, dan memiliki rasa tanggung jawab terhadap lingkungan. Dengan berbagai tantangan masa depan inilah kebijakan kurikulum 2013 ditetapkan.

Kurikulum PAI dan Budi Pekerti dalam kurikulum 2013 mencakup usaha untuk mewujudkan keharmonisan, keserasian, kesesuaian, dan keseimbangan antara hubungan manusia dengan Sang Pencipta (Allah swt), manusia dengan manusia, hubungan manusia dengan makhluk lain dan lingkungan alam, hubungan manusia dengan dirinya sendiri (berakhlak dengan diri sendiri). Keempat hubungan tersebut, tercakup dalam kurikulum PAI yang tersusun dalam beberapa mata pelajaran, yaitu, mata pelajaran akidah akhlak, mata pelajaran ibadah syariah (fiqh), mata pelajaran al-Qur'an Hadis, Mata pelajaran Sejarah dan Kebudayaan Islam (SKI), dan mata pelajaran Bahasa Arab.

Mata-mata pelajaran tersebut merupakan scope atau ruang lingkup kurikulum PAI yang disajikan pada sekolah-sekolah yang berciri khas agama Islam atau madrasah, sementara ruang lingkup kurikulum PAI pada sekolah-sekolah umum adalah mata pelajaran pendidikan agama Islam yang bentuk kurikulumnya broad field atau in one system.

\section{Pendidikan Antinarkoba dalam KI, KD PAI dan Budi Pekerti Kurikulum 2013}

Materi Pendidikan Agama Islam dan Budi Pekerti dalam KI dan KD PAI kurikulum 2013 menunjukkan bahwa pendidikan antinarkoba sudah dimulai sejak SD. Bila diperhatikan metode pendidikan antinarkoba yang berisi tentang tiga hal yaitu: 
pengetahuan tentang narkoba dan bahayanya, peningkatan harga diri, dan pembentukan asertasi, maka kompetensi inti dan kompetensi dasar dari jenjang SD hingga SMA telah memuat hal tersebut. Pada jenjang SD, pendidikan antinarkoba ditekankan pada ranah afektif; pembentukan sikap peserta didik sehingga mampu menghindari narkoba.

Materi PAI yang tercermin pada Kompetensi Inti dan Kompetensi Dasar pada SD lebih menekankan pada pembentukan sikap dan peningkatan harga diri siswa, ataupun pembentukan asertasi. Materi tentang pengetahuan anti narkoba dan bahayanya belum secara eksplisit termuat dalam KI dan KD PAI SD. Hal tersebut karena ada kekhawatiran bila dalam pembelajaran, guru kurang menguasai dalam penyampaiannya maka anak akan tertarik untuk mencoba narkoba. Namun materi yang terkait dalam KI dan KD mulai dari kelas 1 hingga kelas 6 sudah menekankan pentingnya perilaku bersih dan sehat sebagai langkah pertama pendidikan antinarkoba.

Pada jenjang SMP pendidikan anti narkoba telah tertuang dalam materi khusus pada, yakni dalam Kompetensi Inti (KI) dan Kompetensi Dasar (KD) pada kelas VIII, meliputi materi alQur'an dan hadis berkenaan dengan bahaya dan larangan narkoba yang merupakan dasar hukum dalam tindakan. Dalil-dalil pada alQur'an dan hadis tersebut kemudian dikoneksikan dengan berbagai hal seputar narkoba dan bahayanya.

Selain itu, pembentukan sikap dan mental, serta peningkatan harga diri dan asertasi sebagai langkah dalam menanggulangi narkoba baik untuk membentengi diri dari pengaruh narkoba maupun amar ma'rúf kepada sesama teman juga begitu kuat ditanamkan pada kurikulum 2013 ini. Hal tersebut terlihat dari berbagai KD yang ada pada kelas VII s/d kelas IX kurikulum 2013 PAI SMP.

Sedangkan, pada pada KI dan KD SMA yang secara spesifik terkait dengan pendidikan antinarkoba terdapat dalam KD kelas IX antara lain;

1. Menunjukkan perilaku kontrol diri (mujahadah al-nafs), prasangka baik (husn al-žann), dan persaudaraan (ukhuwwah) sebagai implementasi dari pemahaman Q.S. Al-Anfāl/8: 72; al-Ḥujurāt/49: 12 dan 10 serta hadis yang terkait. 
2. Menunjukkan perilaku menghindarkan diri dari pergaulan bebas dan perbuatan zina sebagai implementasi dari pemahaman Q.S. al-Isrā'/17: 32, dan al-Nür/24: 2, serta hadits yang terkait.

3. Memahami dan menganalisis Q.S. al-Anfāi/8: 72; alHujurāt/49: 12; dan al-Ḥujurāt/49: 10; serta hadits tentang kontrol diri (mujahadah al-nafs), prasangka baik (husn alzann), dan persaudaraan (ukhuwah).

\section{E. Analisis Pendidikan Antinarkoba dalam Buku Ajar PAI dan BP Kurikulum 2013}

Analisis pendidikan antinarkoba dalam buku ajar PAI dan Budi Pekerti kurikulum 2013 dalam penelitian ini lebih difokuskan pada materi yang secara eksplisit menerangkan tentang narkoba yaitu pada kelas VIII SMP. Hal ini penulis lakukan untuk menguji apakah materi pembelajaran dalam buku ajar tersebut khususnya pada buku siswa mampu memberikan pendidikan antinarkoba yang komprehensif, sistematis, rasional, dan mampu menyentuh perasaan dan menanamkan keyakinan yang kuat untuk menghindarkan dari narkoba. Sebaliknya, materi pendidikan antinarkoba yang terdapat pada buku ajar hanya mengedapankan sisi kognitif semata tanpa menyentuh aspek afektif dan keterampilan sebagai satu kesatuan dalam kurikulum 2013.

Materi pendidikan antinarkoba dalam kurikulum 2013 pada buku ajar SMP kelas 8 terdapat pada 3 Bab, yaitu Bab 8 dengan tema "Mengonsumsi Makanan dan minuman yang halal dan menjauhi yang haram", Bab 10 dengan tema "Hidup sehat dengan makanan dan minuman yang halal serta bergizi”, serta Bab 11 dengan tema "menghindari minuman keras, judi dan Pertengkaran".

Analisis pada Buku PAI dan Budi Pekerti Kurikulum 2013khususnya pada bab 8, bab 10 dan Bab 11 kelas VIII SMP/MTsmenunjukkan bahwa ulasan cukup lengkap dan komprehensif tentang Pendidikan antinarkoba. Pendidikan antinarkoba tidak hanya merupakan sebuah pengetahuan semata, namun dimulai dengan "renungan" dalam menumbuhkembangkan kesadaran peserta didik dimulai dengan dasar rasional dikaitkan "dialog islami” yang merupakan realitas sehari-hari yang dihadapi.

Begitu pula, dalil naqli ayat al Qur'an maupun hadis yang semakin memperkuat. Kemudian aktivitas siswa, refleksi akhlak 
mulia dan kisah teladan, dan ditutup interaksi antara guru dan orang tua siswa. Jika diimplementasikan secara baik, maka tujuan pendidikan antinarkoba, tidak hanya menekankan pada pengetahuan. Namun, akan tercapai sikap asertif.

\section{F. Integrasi Pendidikan Anti narkoba dalam PAI dan BP Kurikulum 2013}

Secara umum tujuan pendidikan antinarkoba adalah (1) pembentukan pengetahuan dan pemahaman mengenai bentuk narkoba dan aspek-aspeknya; (2) pengubahan persepsi dan sikap terhadap narkoba; dan (3) pembentukan keterampilan dan kecakapan baru yang ditujukan untuk melawan narkoba. Sedangkan manfaat jangka panjangnya adalah menyumbang pada keberlangsungan sistem integrasi nasional dan program antinarkoba pada diri peserta didik yang kelak akan menjalankan amanah di dalam sendi-sendi kehidupan.

Pendidikan antinarkoba yang dimaksud dalam penelitian ini adalah program pendidikan antinarkoba yang secara konsepsional memungkinkan disisipkan pada mata pelajaran yang sudah ada di sekolah dalam bentuk perluasan tema yang sudah ada dalam kurikulum dengan menggunakan pendekatan kontekstual pada pembelajaran antinarkoba. Pilihan ini digunakan oleh karena pertimbangan agar tidak menambah beban kurikulum dan jam belajar siswa. Pada aspek lain, pendidikan antinarkoba dapat juga diimplementasikan dalam bentuk mata pelajaran untuk kegiatan ekstra kurikuler siswa ataupun muatan lokal (institusional).

Ada dua model yang dapat dilakukan oleh sekolah untuk berpartisipasi dalam gerakan pemberantasan narkoba. Pertama, proses pendidikan harus menumbuhkan kepedulian sosialnormatif, membangun penalaran obyektif, dan mengembangkan perspektif universal pada individu. Kedua, pendidikan harus mengarah pada penyemaian strategis, yaitu kualitas pribadi individu yang konsekuen dan kokoh dalam keterlibatan peran sosial.

Dalam pendidikan antinarkoba harus mengintegrasikan tiga domain, yakni domain pengetahuan (kognitif), sikap dan perilaku (afeksi), dan keterampilan (psikomotorik). Implementasi dapat menggunakan strategi integratif-inklusif (disisipkan dalam mata pelajaran yang sudah ada) dan eksklusif (mata pelajaran khusus atau tersendiri). Model pendidikan antinarkoba yang integratif- 
inklusif, yaitu dengan alternatif materi anti-narkoba yang terintegrasi dalam mata pelajaran agama Islam pada kelas VIII SMP dan MTs semester 2, yang memuat Kompetensi Dasar (KD) yang secara eksplisit tentang pendidikan antinarkoba.

Model pendidikan antinarkoba yang integratif-inklusif dalam pendidikan agama Islam, secara aplikatif lebih berkedudukan sebagai pendekatan dalam pembelajaran. Hal tersebut akan tampak dalam desain atau Rencana Pembelajaran setiap mata pelajaran terpilih. Sebagai sebuah pendekatan pembelajaran maka implementasi pendidikan antinarkoba akan sangat tergantung dari kemampuan guru dalam melaksanakan kegiatan belajar-mengajar.

Metode pembelajaran Pendidikan Antinarkoba pada Kurikulum Pendidikan agama Islam adalah: 1) Ceramah dan penugasan; 2) Melibatkan peserta didik secara aktif dan kreatif dalam kegiatan pembelajaran; 3) Pemberian keteladanan; 4) Penelaahan berbagai modus operandi narkoba; 5) Studi kasus atau lapangan dan pemecahan masalah; 6) Pelatihan dan penyuluhan, dan 7) pelibatan siswa sebagai duta dan satgas antinarkoba.

Upaya pencegahan penggunaan narkoba bisa dilakukan dengan dua langkah, yaitu langkah preventif dan kuratif. Langkah preventif melalui pendidikan, dilakukan dengan cara internalisasi nilai-nilai antinarkoba terhadap peserta didik sebagai generasi penerus bangsa. Konsep pendidikan antinarkoba yang digagas sebagai solusi atas permasalahan bangsa adalah upaya mencegah berkembangnya peredaran narkoba pada anak bangsa Indonesia melalui pendidikan. Secara sederhana, langkah tersebut ditujukan untuk pemberdayaan peserta didik untuk Adapun Langkah represif dilakukan dengan cara menjalankan penegakan hukum yang tegas, pembinaan kepada pengguna dan hukuman oleh para aparat penegak hukum sehingga mencegah timbulnya penggunaan narkoba pada generasi muda bangsa.

Dalam manajemen pembelajaran semacam ini dapat dilakukan di semua mata pelajaran, baik agama maupun umum seperti mata pelajaran Pendidikan Jasmani Olahraga dan Kesehatan (PJOK), meliputi narkoba dan bahayanya, kesehatan reproduksi dan lainlain. Proses pembelajaran dapat dimulai dengan mengamati (observing) video yang menunjukkan fakta-fakta ilmiah, kemudian mengintegrasikannya dengan sains-al-Qur'an dan Hadits. Lagilagi, kemampuan semacam ini harus didukung dengan wawasan, 
bacaan, pengalaman, dan literatur memadai bagi guru yang melekat pada kompetensi pedagogik dan profesional.

Di ujung proses pembelajaran, pendidik secara bersama-sama menyimpulkan tentang sikap atau nilai. Maka, integrasi interkoneksi manajemen pembelajaran semacam ini akan menghasilkan peserta didik yang "berilmu amaliyah, beramal ilmiah, dan berakhlakul karimah".

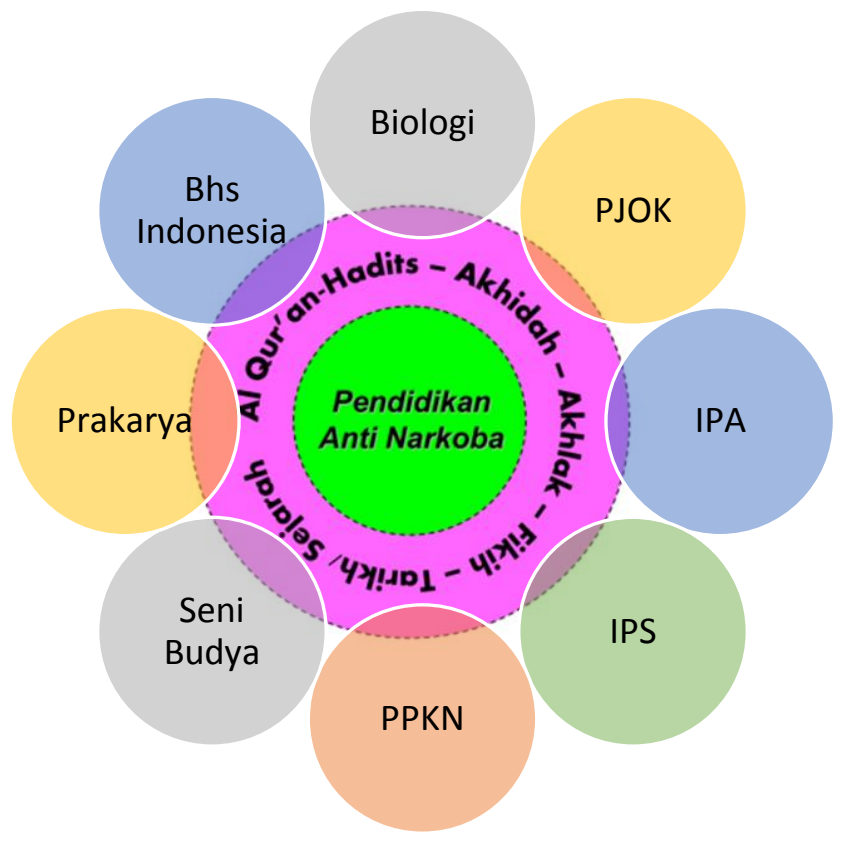

Gambar 1

Integrasi Pendidikan Anti Narkoba pada Kurikulum 2013

\section{G. Penutup}

Sebagai penutup pembahasan Integrasi Pendidikan Antinarkoba dalam Pendidikan Agama Islam dan Budi Pekerti Kurikulum 2013 adalah Materi Pendidikan Agama Islam dan Budi Pekerti dalam KI dan KD PAI kurikulum 2013 pendidikan antinarkoba sudah dimulai sejak SD, SMP dan SMA yang mencakup pengetahuan tentang narkoba dan bahayanya, peningkatan harga diri, dan pembentukan asertasi.

Pendidikan anti narkoba pada kurikulum Pendidikan Agama Islam dan Budi Pekerti diintegrasikan dengan mencakup tiga 
domain, yakni domain pengetahuan (kognitif), sikap dan perilaku (afeksi), dan keterampilan (psikomotorik).

Implementasi pendidikan antinarkoba di jenjang sekolah dapat menggunakan strategi integratif-inklusif (disisipkan dalam mata pelajaran yang sudah ada) dan eksklusif (mata pelajaran khusus atau tersendiri).

Manajemen pembelajaran pendidikan antinarkoba dapat diintegrasikan di semua mata pelajaran, baik agama maupun umum. Seperti mata pelajaran Pendidikan Jasmani Olahraga dan Kesehatan PJOK, meliputi tentang narkoba dan bahayanya, kesehatan reproduksi dan lainnya.

\section{Kepustakaan}

Tim Badan Narkotika Nasional, Materi Advokasi Pencegahan Penyalahgunaan Narkoba, (Jakarta: Badan Narkotika Nasional, 2005).

------, Materi Advokasi Pencegahan Narkoba, (Jakarta: Badan Narkotika Nasional, 2005).

------, Mencegah Lebih Baik Daripada Mengobati, (Bandung: Remaja Rosdakarya, 2007).

------, Pencegahan Penyalahgunaan Narkoba Berbasis Sekolah Melalui Program Anti Drugs Campaign Goes To School. (Jakarta: Badan Narkotika Nasional, 2008).

Tim Departemen Pendidikan Nasional, Rokok, Minuman Keras, dan Narkoba, (Jakarta: Pusat Pengembangan Kualitas Jasmani, 2000).

Tim Direktorat Jenderal Pendidikan Islam, Direktorat Pendidikan Agama Islam, Pedoman Umum Implementasi Kurikulum 2013, (Jakarta: Kementerian Agama RI, 2013).

Doll, Ronald C., Curriculum Improvemet Decision Making and Process, (Boston: Nallyn Bacon, 1996).

Good, Carter V. ed., Dictionary of Education, (New York: McGraw-Hill, 1996).

Jawa Post, Minggu 8 Februari 2015

Tim Kemendikbud. Kurikulum 2013, (Jakarta: Kementerian Pendidikan dan Kebudayaan Republik Indonesia, 2013). 
Machali, Imam, "Dimensi Kecerdasan Majemuk (Multiple Intellegences) dalam Kurikulum 2013", Insania, (Volume 19 Nomor 2/Juli-Desember 2014), hlm. 93-117.

-----, "Kebijakan Perubahan Kurikulum 2013 Dalam Menyongsong Indonesia Emas Tahun 2045", Jurnal Pendidikan Islam (Volume III No 1 Juni 2014/1345), hlm. 71-94.

Nasution, S., Pengembangan Kurikulum, (Bandung: Citra Aditya Bakti, 2003).

Oliva, Peter F., Developing the Curriculum, (New York: HarperCollins, 1992).

Peraturan Menteri Pendidikan dan Kebudayaan RI Nomor 81A Tahun 2013 Tentang tentang Implemetasi Kurikulum 2013.

Permendikbud No 57 tahun 2014 tentang Kurikulum SD

Permendikbud No 58 tahun 2014 tentang Kurikulum SMP/MTs

Permendikbud No 59 tahun 2014 tentang Kurikulum SMA/SMK/MA

Peraturan Pemerintah nomor 32 Tahun 2013 tentang Perubahan atas Peraturan Pemerintah Nomor 19 Tahun 2005 tentang Standar Nasional Pendidikan.

Sanjaya, Wina, Kurikulum dan Pembelajaran, (Jakarta: Kencana, 2008).

Soetopo, Hendyat dan Wasty Soemanto, Pembinaan dan Pengembangan Kurikulum, (Jakarta: Bina Aksara, 1986).

Spencer, Lyle M., Competence at Work: Models for Superior Performance, (Canada: John wiley \& Son, 1993).

Suara Karya, Jum'at 12 April 2013

Utami, Arini dkk, Katakan Tidak pada Narkoba: Mengenal Narkoba dan Bahayanya, (Bandung: Sarana Penunjang Pendidikan, 2006).

Undang-Undang RI Nomor 35 tahun 2009 tentang Narkotika.

Undang-Undang RI Nomor 20 tahun 2003 tentang Sistem Pendidikan Nasional. 


\title{
Teori Pendidikan Keluarga dan Tanggung Jawab Orang Tua dalam Pendidikan Anak Usia Dini
}

\author{
M. Syahran Jailani \\ IAIN Sulthan Thaha Saifuddin Jambi \\ E-mail: m.syahran@ymail.com
}

\begin{abstract}
This paper describes the responsibilities of parents in early childhood education. From the review of the literature it is known that the family environment becomes a major place of a child to education. Father and mother in the family becomes the first educators in the process of development of a child's life. Parents do not just build a relationship and do various family for reproductive purposes, continue descent, and establish affection. The main task of the family is to create buildings and atmosphere of family education process so that the next generation of intelligent and noble generation as a solid footing in the tread life and the journey of human children. The fact is supported by the findings of the theories that support the importance of family education as the first basic education of children.
\end{abstract}

Keywords: family, education, early children

\begin{abstract}
Abstrak
Makalah ini menjelaskan tanggung jawab orang tua dalam pendidikan anak usia dini. Dari kajian literatur diketahui bahwa lingkungan keluarga menjadi tempat yang utama seorang anak memperoleh pendidikan. Ayah dan ibu dalam keluarga menjadi pendidik pertama dalam proses perkembangan kehidupan anak. Orang tua tidak sekedar membangun silaturahmi dan melakukan berbagai tujuan berkeluarga untuk reproduksi, meneruskan keturunan, dan menjalin kasih sayang. Tugas utama keluarga adalah menciptakan bangunan dan suasana proses pendidikan keluarga sehingga melahirkan generasi yang cerdas dan berakhlak mulia sebagai pijakan yang kokoh dalam menapaki kehidupan dan perjalanan anak manusia. Kenyataan tersebut ditopang temuan teori-teori yang mendukung pentingnya pendidikan keluarga sebagai dasar pertama pendidikan anak-anak.
\end{abstract}

Kata Kunci: keluarga, pendidikan, anak usia dini. 


\section{A. Pendahuluan}

Keluarga sebagai sebuah lembaga pendidikan yang pertama dan utama. Keluarga diharapkan senantiasa berusaha menyediakan kebutuhan, baik biologis maupun psikologis bagi anak, serta merawat dan mendidiknya. Keluarga diharapkan mampu menghasilkan anak-anak yang dapat tumbuh menjadi pribadi, serta mampu hidup di tengah-tengah masyarakat. Sekaligus dapat menerima dan mewarisi nilai-nilai kehidupan dan kebudayaan. Menurut Selo Soemarjan, keluarga adalah sebagai kelompok inti, sebab keluarga adalah masyarakat pendidikan pertama dan bersifat alamiah. Dalam keluarga, anak dipersiapkan untuk menjalani tingkatan-tingkatan perkembangannya sebagai bekal ketika memasuki dunia orang dewasa, bahasa, adat istiadat dan seluruh isi kebudayaan, seharusnya menjadi tugas yang dikerjakan keluarga dan masyarakat di dalam mempertahankan kehidupan oleh keluarga. ${ }^{1}$

Dalam wahana keluarga, orang tua terutama ayah sebagai kepala keluarga dengan bantuan anggotanya harus mampu mempersiapkan segala sesuatu yang dibutuhkan sebuah keluarga. Seperti bimbingan, ajakan, pemberian contoh, kadang sanksi yang khas dalam sebuah keluarga, baik dalam wujud pekerjaan kerumahtanggaan, keagamaan maupun kemasyarakatan lainnya, yang dipikul atas seluruh anggota keluarga, atau secara individual, termasuk interaksi dalam pendidikan keluarga. Menurut Ki Hajar Dewantara, keluarga adalah kumpulan individu yang memiliki rasa pengabdian tanpa pamrih, demi kepentingan seluruh individu yang bernaung di dalamnya. Begitu pentingnya keluarga dari kehidupan manusia bagi individu maupun sekelompok orang. ${ }^{2}$

Anak tidak bisa dipisahkan dari keluarga, dengan keluarga orang dapat berkumpul, bertemu dan bersilaturahmi. Dapat dibayangkan jika manusia hidup tanpa keluarga. Tanpa disadari secara tidak langsung, telah menghilangkan fitrah seseorang sebagai makhluk sosial. Hal ini sejalan dengan pernyataan Selo Soemarjan, keluarga adalah sekelompok orang yang dipersatukan oleh pertalian kekeluargaan, perkawinan atau adopsi yang disetujui

1 Selo Soemarjan, Sosiologi Suatu Pengantar, (Yogyakarta: Gajah Mada Press, 1962), hlm. 127.

${ }^{2}$ Ki Hajar Dewantara, Ilmu Pendidikan, (Yogyakarta: Taman Siswa, 1961), hlm. 250. 
secara sosial dan pada umumnya sesuai dengan peranan-peranan sosial yang telah dirumuskan dengan baik. ${ }^{3}$

Abdullah dan Berns juga memperkuat agrumen, bahwa keluarga adalah suatu kelompok sosial yang ditandai oleh tempat tinggal bersama kerja sama ekonomi, dan reproduksi. ${ }^{4}$ Di sisi lain, dalam konteks pengertian psikologis, keluarga dimaknai sebagai kumpulan orang yang hidup bersama dengan tempat tinggal bersama dan masing-masing orang yang terlibat di dalamnya merasakan adanya pertautan batin sehingga terjadi saling memperhatikan, saling membantu, bersosial dan menyerahkan diri. $^{5}$

Begitu pula dalam kaitan pandangan pedagogis. Keluarga adalah satu persekutuan hidup yang dijalin oleh kasih sayang antara pasangan dua jenis manusia yang dikukuhkan dengan pernikahan dengan maksud untuk saling menyempurnakan. ${ }^{6}$

Selain itu, keluarga menjadi tempat untuk mendidik anak agar pandai, berpengalaman, berpengetahuan, dan berperilaku dengan baik. Kedua orang tua harus memahami dengan baik kewajiban dan tanggung jawab sebagai orang tua. Orang tua (ayah dan ibu) tidak hanya sekedar membangun silaturahmi dan melakukan berbagai tujuan berkeluarga, seperti reproduksi, meneruskan keturunan, menjalin kasih sayang dan lain sebagainya.

Tugas keluarga sangat urgen, yakni menciptakan suasana dalam keluarga proses pendidikan yang berkelanjutan (continues progress) guna melahirkan generasi penerus (keturunan) yang cerdas dan berakhlak (berbudi pekerti yang baik). Baik di mata orang tua, dan masyarakat.

Fondasi dan dasar-dasar yang kuat adalah awal pendidikan dalam keluarga, dasar kokoh dalam menapaki kehidupan yang lebih berat, dan luas bagi perjalanan anak-anak manusia berikutnya.

Sebagaimana yang telah digambarkan Allah swt. dalam kitab suci al-Qur'an, yang tertera pada Q.S. al-Nisā/4: 58; alTahrỉm/56: 6; Hūd/11: 46; al-Anfāl/8: 28; al-Kahfi/18: 48, di mana

${ }^{3}$ Soemarjan, Sosiologi Suatu Pengantar ..., hlm. 127.

4 M. Imron Abdullah, Pendidikan Keluarga Bagi Anak, (Cirebon: Lektur, 2003), hlm. 225.

${ }^{5}$ Robert M. Berns, Child, Family, School, Community Socilization and Support, (United State: Thomson Corporation, 2007), hlm. 87.

${ }^{6}$ Berns, Child, family ..., hlm. 88. 
ayat-ayat tersebut mengisyaratkan pentingnya mendidik anak dalam lingkup keluarga. ${ }^{7}$

\section{B. Pendidikan Keluarga: Nilai Pentingnya bagi Anak}

1. Pengertian Pendidikan Keluarga

Dalam berbagai literatur, para ahli memberikan berbagai sudut pandang tentang pengertian pendidikan keluarga. Misalnya Mansur, mendefinisikan pendidikan keluarga adalah proses pemberian nilai-nilai positif bagi tumbuh kembangnya anak sebagai fondasi pendidikan selanjutnya. ${ }^{8}$ Selain itu, Abdullah juga mendefinisikan pendidikan keluarga adalah segala usaha yang dilakukan oleh orang tua berupa pembiasaan dan improvisasi untuk membantu perkembangan pribadi anak. ${ }^{9}$ Pendapat lain yang dikemukakan oleh anNahlawi, Hasan Langgulung memberi batasan terhadap pengertian pendidikan keluarga sebagai usaha yang dilakukan oleh ayah dan ibu sebagai orang yang diberi tanggung jawab untuk memberikan nilai-nilai, akhlak, keteladanan dan kefitrahan. ${ }^{10}$

Ki Hajar Dewantara merupakan salah seorang tokoh pendidikan Indonesia, juga menyatakan bahwa alam keluarga bagi setiap orang (anak) adalah alam pendidikan permulaan. Untuk pertama kalinya, orang tua (ayah maupun ibu) berkedudukan sebagai penuntun (guru), sebagai pengajar, sebagai pendidik, pembimbing dan sebagai pendidik yang utama diperoleh anak. Maka tidak berlebihan kiranya manakala merujuk pada pendapat para ahli di atas konsep pendidikan keluarga. Tidak hanya sekedar tindakan (proses), tetapi ia hadir dalam praktek dan implementasi, yang dilaksanakan orang tua (ayah-ibu) degan nilai pendidikan pada keluarga. ${ }^{11}$

7 A. Soenarjo, Al-Qur'an dan Terjemahan Departemen Agama RI, (Jakarta: Teraju, 1989).

8 Mansur, Pendidikan Anak Usia Dini dalam Islam, (Yogyakarta: Pustaka Pelajar, 2005), hlm. 319.

${ }^{9}$ Abdullah, Pendidikan Keluarga ..., hlm. 232.

${ }^{10}$ Hasan Langgulung, Manusia dan Pendidikan, (Jakarta: Pustaka alHusna, 1986), hlm. 19.

${ }^{11}$ Dewantara, Ilmu Pendidikan, ..., hlm. 255. 
Perlu diketahui, mayoritas orang tua belum mengetahui bagaimana konsep pendidikan keluarga itu. Hal tersebut tanpa disadari para orang tua (ayah dan ibu) dalam praktek kesehariannya. Mereka telah menjalankan fungsi keluarga dalam pendidikan anak-anak. Pada hakikatnya, fungsi keluarga adalah sebagai pendidikan budi pekerti, sosial, kewarganegaraan, pembentukan kebiasaan dan pendidikan intelektual anak.

a. Mollehnhaur dalam Abdullah membagi tiga fungsi keluarga dalam pendidikan anak, yaitu:

b. Fungsi kuantitatif, yaitu menyediakan bagi pembentukan perilaku dasar, artinya keluarga tidak hanya menyediakan kebutuhan dasar fisik anak, berupa pakaian, makanan dan minuman, serta tempat tinggal yang layak. Akan tetapi, keluarga dituntut untuk menyediakan dan memfasilitasi ketersediaan dasar-dasar kebaikan, berupa perilaku, etika, sopan santun dan pembentukan karakter anak yang santun dan berakhlak baik sebagai fitrah manusia yang hakiki.

c. Fungsi-fungsi selektif, yaitu menyaring pengalaman anak dan ketidaksamaan posisi kemasyarakatan karena lingkungan belajar. Artinya pendidikan keluarga berfungsi sekaligus memerankan diri sebagai fungsi kontrol pengawasan terhadap diri anak akan berbagai informasi yang diterima anak. ${ }^{12}$ Terutama anak usia 00 tahun hingga 05 tahun yang belum memiliki pengetahuan dan pengalaman. Sehingga diharapkan mampu membedakan mana yang baik dan buruk. Oleh sebab itu, keluarga (ayah dan ibu) berkewajiban memberikan informasi dan pengalaman yang bermakna. Berupa pengalaman belajar secara langsung maupun tidak langsung, diharapkan pengalaman tersebut mampu diserap dan ditransformasi dalam diri anak.

d. Fungsi pedagogis, yaitu mewariskan nilai-nilai dan normanorma. Artinya pendidikan keluarga berfungsi memberikan warisan nilai-nilai yang berkaitan dengan aspek kepribadian anak. Tugas akhir pendidikan keluarga tercermin dari sikap, perilaku dan kepribadian 
(personality) anak dalam kehidupan sehari-hari yang ditampilkan.

Sementara itu, ternyata fungsi keluarga bukan sebatas itu, misalnya Berns ${ }^{13}$, ia mengemukakan fungsi keluarga, yaitu: (a) fungsi reproduksi, (b) melaksanakan pendidikan dan sosialisasi di masyarakat, (c) membangun aturan-aturan sosial, (d) melakukan tindakan ekonomi, dan (e) membangun dan mendukung proses perkembangan emosi anak-anak.

2. Teori-teori Pendidikan Keluarga pada Anak Usia Dini

a. J.H. Pestolozzi (1746 - 1827).

Tokoh pendidikan lainnya yang juga telah meletakkan fondasi bagi pendidikan anak sejak dini adalah Johan Hendrik Pestolozzi. Ia dilahirkan di Zurich Swiss tahun 1746. Pada tahun 1774 ia memulai dengan mendirikan sekolah pertama yang disebut "Neuhof' di sebuah lahan pertanian miliknya. Di tempat tersebut ia mengembangkan ide-idenya dalam dunia pendidikan, di mana ide yang paling difokuskan adalah bagaimana mengintegrasikan pendidikan di kehidupan rumah tangga, pendidikan vokasional dan pendidikan membaca dan menulis.

Pestolozzi berpandangan bahwa pendidikan sebaiknya mengikuti sifat-sifat bawaan anak (child's nature). Dasar dari pendidikan ini menggunakan metode, yang merupakan perpaduan antara dunia alam terutama alam keluarga dan pendidikan yang praktis. Cara ialah membimbing anak dengan perlahan-lahan. Bisa dengan cara memulai usaha anak sendiri, yakni memberi kesempatan anak untuk berbuat dan melakukan sesuatu yang bermula dari "senseimpression" menuju ide-ide yang abstrak.

Pestolozzi yakin bahwa segala bentuk pendidikan adalah berdasarkan pengaruh dari pancaindera, dan melalui pengalaman serta potensi-potensi yang dimiliki untuk dikembangkan. Lingkungan rumah tangga dianggap sebagai pusat kegiatan bagi para ibu dalam mendidik anak, ibu mempunyai tanggung jawab yang terbesar dalam pendidikan anak. Maka Pestolozzi menganggap bahwa ibu adalah pahlawan dalam bidang pendidikan anak mereka.

${ }^{13}$ Berns, Child, family ..., hlm. 89-90. 
Ibu adalah orang yang mendorong anaknya untuk belajar sejak awal hidup anak. ${ }^{14}$

b. Friedrich Frobel ( $1782-1852)$

Ia lahir di kota Oberweisbach, Jerman pada tahun 1782. Frobel banyak belajar tentang konsep pendidikan dari pendahulunya, J.H. Pestolozzi yang dianggap olehnya sebagai "Bapak" pendidikan dan pembelajaran anak-anak. Pada tahun 1817 Frobel mendirikan perguruan di Kota Keilhau (Jerman) dengan memakai sistem dari Pestolozzi. Khusus untuk pendidikan anak-anak, Frobel mendirikan "Kindergarten" (taman kanak-kanak). Itulah sekolah pertama Frobel yang berdiri di kota Blanckenburg, Jerman. Selain ia mendirikan taman kanak-kanak (Kindergarten), juga mendirikan "taman ibu" (Frobel Kweekschool).

Di dalam pendidikan anak yang digagas Frobel, di antaranya bermainan, bernyanyi dan berbagai macam pekerjaan anak-anak yang diberikan, guna memberi pengalaman langsung kepada anak. Bagi Frobel, jika anakanak tidak bergerak dan lebih banyak diam, maka pertanda anak itu kurang sehat badan atau jiwanya. Bergeraknya anak-anak adalah akibat dari gerakan jiwanya, karena jiwa dan tubuh anak-anak bersifat satu. Gerakan badan akan mempengaruhi jiwa anak-anak untuk tumbuh kembang.

Konsep pendidikan Frobel ini pula yang mengilhami dirinya untuk menciptakan berbagai macam bentuk permainan, agar diharapkan mampu melahirkan anak-anak yang sehat, baik jasmani maupun rohani. Permainanpermainan yang digagas Frobel's School dapat dilakukan manakala dengan memperhatikan syarat-syarat sebagai berikut:

1) Permainan harus menyenangkan anak-anak,

2) Permainan harus memberi kesempatan pada anakanak untuk berfantasi,

3) Anak-anak harus cakap dan mampu menyelesaikan permainan,

4) Berilah pekerjaan permainan yang juga mengandung kesenian, dan

14 Soemiarti Patmonodewo, Pendidikan Anak Prasekolah, (Jakarta: Rineka Cipta, 2003), hlm. 5-6. 
5) Permainan diharapkan mengandung dan mengarahkan anak-anak ke arah ketertiban. Ketertiban tersebut dimaksudkan oleh Frobel untuk mendidik anak-anak "rasa kesusilaan", dan kelak diharapkan anak memiliki sikap kemasyarakatan dan kemanusiaan. ${ }^{15}$

c. Maria Montessori (1870-1952)

Ia dilahirkan di Italia (Roma) pada tahun 1870. Ia seorang dokter wanita dan menghentikan praktek kedokterannya pada tahun 1900. Kemudian terjun ke dunia pendidikan dengan mempelajari ilmu jiwa anak-anak (Kinder Psychologie).

Pada tahun 1907 Maria Montessori mendapat tawaran dari seorang pengusaha Roma untuk mendirikan sekolah bagi kanak-kanak. Oleh pengusaha kaya tersebut, Montessori diberi wewenang untuk mengelola sekolah tersebut dengan baik. Tawaran tersebut diterimanya dan Maria Montessori, akhirnya ia mendirikan "Casa Dei Bambini" yang berarti "rumah untuk merawat anak-anak". Montessori, memandang perkembangan anak usia dini sebagai suatu proses yang berkesinambungan. Pendidikan adalah sebagai aktivitas diri, dan mengarahkan anak pada pembentukan disiplin pribadi, kemandirian, dan pengarahan diri.

Demi memenuhi kebutuhan pendidikan anak tersebut, ia merancang sejumlah materi yang memungkinkan indra anak dapat berkembang dengan baik dan sempurna. Bila anak belajar tentang suara (melalui pendengaran), Montessori merancang suatu kumpulan kotak. Semua kotak tersebut sama, tetapi masing-masing kotak berisi bahan yang berbeda-beda, sehingga bila digoyangkan akan mengeluarkan suara yang tidak sama. Selanjutnya Montessori merancang alat belajar untuk meningkatkan fungsi penglihatan, penciuman, pengecap, dan perabaan, dengan cara sangat khas dan prinsip evaluasi diri.

Tak kalah menarik dari konsep teori pendidikan Montessori adalah pendidikan jasmani yang mengembangkan otot-otot, berkebun dan belajar tentang alam. Dengan pendidikan tentang alam, berkebun dan

${ }^{15}$ Patmonodewo, Pendidikan Anak Prasekolah ..., hlm. 6-8. 
mengembangkan otot-otot melalui olah raga diharapkan anak-anak akan memiliki pengalaman kehidupan dan memiliki fisik yang sehat dan kuat. Dengan demikian, anak akan dapat belajar dengan berbagai macam pengetahuan. Ia percaya bahwa pada usia sejak dini $02-06$ tahun adalah masa yang dianggap sangat "sensitif" untuk belajar mengenal membaca, dan menghitung. ${ }^{16}$

d. Abu Hamid Muhammad Al-Gazali (1058 M - 1111 M)

Al-Gazali dilahirkan di Kota Tos Khurasan (Persia). Sejak kecil al-Gazali menggemari ilmu pengetahuan, ia memiliki kecerdasan yang luar biasa. Sampai-sampai Imam Al-Juwaini menjuluki dengan sebutan "Bahr Mugriq" (lautan yang menenggelamkan). Kelebihan lain dari al-Gazali, adalah kemampuan ia terlibat dalam perdebatan (dialog) dengan beberapa ahli pikir, ulama dan orang-orang yang dianggap memiliki kelebihan ilmu darinya. Kemampuannya dalam berdebat ini telah menghantarkannya untuk diminta oleh penguasa (raja) ketika itu untuk membantu dalam mendidik dan mengajarkan ilmu agama kepada anak-anak Raja dan para prajuritnya di kota Baghdad (Irak sekarang), ini terjadi tahun $484 \mathrm{H} / 1091 \mathrm{M}$.

Keluasan dan kearifan Imam al-Gazali dalam menata kehidupan di dunia ini telah pula menghantarkannya ke jalan kehidupan sufistik. Ini ditandai dengan ajaranajarannya yang kemudian menjadi rujukan dan referensi bagi orang-orang yang ingin mendalami hakikat melalui ajaran tasawuf. Buku yang pertama kali disusun untuk mengetahui kehidupannya, beliau susun dalam "alMunqidz min al-Dalal". Di dalam buku ini berisi dan memuat gambaran kehidupan, terutama pada masa terjadi perubahan di dalam pandangannya tentang perihal hidup dan nilai-nilai. al-Gazali melukiskan proses internalisasi Iman di dalam jiwa, bagaimana hakikat-hakikat ilahiah dapat tersingkap bagi manusia. Bagaimana manusia dapat mencapai ma'rifat dengan penuh keyakinan tanpa melalui

\footnotetext{
${ }^{16}$ Soemiarti Patmonodewo, Pendidikan Anak Prasekolah, hlm. 9-10.
} 
proses berpikir dan berlogika, melainkan dengan jalan ilham dan pelacakan sufi. ${ }^{17}$

Al-Gazali dalam konsep pendidikan mengatakan bahwa pendidikan agama harus dimulai sejak usia dini. Sebab, dalam keadaan ini anak siap untuk menerima aqidah-aqidah agama semata-mata atas dasar iman, tanpa meminta dalil untuk menguatkannya, atau menuntut kepastian dan penjelasan. Oleh karena itu, dalam mengajarkan agama kepada anak-anak, hendaknya dimulai dengan menghafal kaidah-kaidah dan dasar-dasarnya. Setelah itu baru guru menjelaskan maknanya, sehingga mereka memahami, meyakini dan membenarkannya.

Anak usia dini menurut al-Gazali seharusnya dikenalkan dengan agama. Karena manusia dilahirkan telah membawa agama sebagaimana agama yang dibawa oleh kedua orang tuanya (ayah-ibu). Oleh karena itu seorang anak akan mengikuti agama kedua orang tua serta guru. Konsep ini menjadikan kedua orang tua sebagai pendidik yang utama menjadi kekuatan dalam diri anak, agar anak tumbuh dan kembang ke arah penyucian jiwa, berakhlak yang mulia bertakwa dan diharapkan menyebarkan keutamaan ke seluruh umat manusia.

Pemikiran Al-Gazali tentang konsep pendidikan, beliau tuangkan dalam kitabnya yang terkenal, yaitu "Ihya' 'Ulum al-Din". Karangan beliau ini hari ini menjadi rujukan dan landasan sebagian pemikir muslim yang mengangkat isu-isu pendidikan, terutama pendidikan keluarga.

e. Ki Hajar Dewantara (1889 - 1959)

Salah seorang tokoh yang berpengaruh dalam dunia pendidikan di Indonesia adalah Ki Hajar Dewantara. Beliau dilahirkan di daerah kauman, Yogyakarta, pada tanggal 2 Mei 1889 dan wafat pada tanggal 26 April 1959. Di Kota Pendidikan inilah, Ki Hajar Dewantara mengilhami lahirnya Perguruan Nasional Taman Siswa di Yogyakarta, pada tanggal 3 Juli 1922. Tahun pertama

17 Fathiyah Hasan Sulaiman, Alam Pikiran Al-Ghazali Mengenai Pendidikan dan Ilmu, (Bandung: Diponegoro, 1986), hlm. 19-22. 
berdirinya, Taman Siswa mulai membuka sekolah yang diberi nama "Taman Lare" atau "Taman Anak".

Dalam perkembangan selanjutnya, berdiri pula sekolah rendah dan sekolah lanjutan pertama di Perguruan Nasional Taman Siswa. Untuk kesesuaian dengan sifatsifat jiwa anak-anak sesuai dengan umurnya, maka setiap jenjang pendidikan diberi nama. "Taman Anak" untuk kelas I sampai dengan kelas III untuk usia anak $7-9$ tahun. "Taman Muda" untuk anak-anak muda untuk anak kelas IV sampai dengan VI berumur antara 10 - 13 tahun. Kemudian untuk kelas VII dan sekolah lanjutan pertama diperuntukkan bagi anak-anak dewasa diberi nama "Taman Dewasa".

Konsep Ki Hajar Dewantara tentang pendidikan beliau tuangkan melalui "Tri Sentra Pendidikan" yang dikembangkan di Perguruan Taman Siswa, yaitu sentra keluarga, sentra perguruan dan sentra masyarakat. Dalam konteks sentra keluarga, pendidikan keluarga telah melahirkan konsep "among", di mana konsep ini menuntut para orang tua untuk bersikap, yaitu: (a) ing ngarso sung tolodo, (b) ing madya mangun kasra, (c) tut wuri handayani.

Dalam konteks sentra keluarga, Ki Hajar Dewantara sangat peduli dalam memperhatikan, bahkan meminta para orang tua untuk mendidik anak-anak sejak usia dini (alam keluarga). Alam keluarga itu adalah suatu tempat yang sebaik-baiknya untuk melakukan pendidikan kesusilaan dan kesosialan. Sehingga boleh dikatakan, bahwa keluarga itu tempat pendidikan yang lebih sempurna sifat dan wujudnya dari pada tempat-tempat lainnya, guna untuk melangsungkan pendidikan ke arah kecerdasan budi pekerti (pembentukan watak individual) dan sebagai persediaan hidup kemasyarakatan. ${ }^{18}$

Pentingnya pendidikan keluarga bagi pertumbuhan dan perkembangan anak di kemukakan lebih lanjut oleh Ki Hajar Dewantara (1961) bahwa alam keluarga, adalah:

1) Alam pendidikan yang permulaan, pendidikan pertama kalinya bersifat pendidikan dari orang tua yang

${ }^{18}$ Dewantara, Ilmu Pendidikan ..., hlm. 374. 
berkedudukan sebagai guru (penuntut), sebagai pengajar dan sebagai pemimpin,

2) Di dalam keluarga itu anak-anak dididik,

3) Di dalam keluarga anak-anak berkesempatan mendidik diri sendiri, karena di dalam hidup keluarga itu mereka tidak berbeda kedudukannya,

4) Di dalam keluarga orang tua sebagai guru dan penuntun, sebagai pengajar, sebagai pemberi contoh dan teladan bagi anak-anak.

f. Engku Muhammad Syafe'i

Engku Muhammad Syafe'i lahir di Kalimantan Barat, tepatnya di daerah Natan, pada tahun 1895 dan ia berdarah Minang. Anak dari Mara Sutan dan Indung Khodijah. Setelah Ki Hajar Dewantara mendirikan perguruan Nasional Taman Siswa di Yogyakarta. Di wilayah Sumatera muncul seorang penggagas yang cerdas dan memiliki pemikiran progresif dari kaum terpelajar Sumatera, terutama Sumatera Barat. Dengan latar belakang pendidikan yang ditempuh selama di Jawa dan didukung latar belakang kehidupan keluarga yang memahami arti penting pendidikan dan perjuangan, maka di tangan Muhammad Syafe'i tahun 1926 lahirlah Indonesisch Nederlansche School (INS) Kayu Tanam, tepatnya pada tanggal 31 Oktober 1926.

Kehadiran INS Kayu Tanam, di bumi Sumatera sebagai lembaga pendidikan telah melahirkan harapan baru di kalangan masyarakat pribumi. Sesuai dengan citacitanya, sekolah berfungsi mengasah kecerdasan dan akal budi murid, bukan membentuk manusia lain dari dirinya sendiri. Tujuan pendidikan dari INS Kayu Tanam adalah melahirkan manusia yang kreatif, inovatif, intelektual, berakhlak mulia, mandiri, cerdas dan beretos kerja. Selanjutnya Engku Muhammad Syafe'i dalam Anfasa Moelok ${ }^{19}$ menyatakan bahwa:

"Mendidik dan membina siswa hendaknya senantiasa kreatif dalam mengembangkan bakat dan keilmuannya, mandiri, cerdas dan beretos kerja, berkemampuan

19 Anfasa Moeloek, Fasli Jalal \& Farid, Bahan Seminar ISN Kayu Tanam, (2006), hlm. 112. 
intelektual, berwawasan dan berbudaya, beriman, bertakwa serta berakhlak mulia dalam pengabdiannya kepada masyarakat".

Begitu bermakna dan dalamnya konsep pendidikan yang ditawarkan oleh Engku Muhammad Syafe'i, sehingga telah mencuri banyak perhatian para orang tua, terutama di wilayah bumi Minangkabau. Hanya beberapa tahun berdiri, keagungan konsep pendidikan yang dilakukan INS Kayu Tanam itu tersebar, terlebih dengan filosofisnya yang sangat terkenal yaitu "Alam ta Kambang jadi Guru". Pendidikan sebagai simbol kemajuan bangsa. Ucapan beliau sampai hari ini masih menjadi semangat pendorong bagi kemajuan pendidikan INS Kayu Tanam, yakni "pendidikan salah satu alat yang terbesar untuk kemajuan bangsa dan akhirat". ${ }^{20}$

Memaknai apa yang dikembangkan Engku Muhammad Syafe'i melalui pendidikan INS Kayu Tanam, sangat nyata sekali bahwa dalam kultur masyarakat Minangkabau senantiasa menjunjung tinggi tradisi budaya. Hampir sebagian besar konsep belajarnya, menyesuaikan tradisi masyarakat Minangkabau, yang kuat akan nilai-nilai agama dalam memegang akidah Islam. Engku Muhammad Syafe'i sangat meyakini melalui kekuatan sendi keagamaan (Islam), pendidikan akan melahirkan anakanak dan generasi yang berakhlak mulia sebagaimana konsep dari tujuan pendidikannya.

\section{Implikasi Teori-teori Pendidikan Keluarga pada Anak Usia Dini}

Undang-undang sistem pendidikan nasional nomor 20 Tahun 2003, Bab I Pasal 1 ayat 13, menyebutkan bahwa "pendidikan informal adalah jalur pendidikan keluarga dan lingkungan." Selanjutnya pasal-pasal 27 ayat 1, mempertegas bahwa "kegiatan pendidikan informal yang dilakukan oleh keluarga dan lingkungan berbentuk kegiatan belajar secara mandiri”. Berdasarkan Undang-undang di atas, secara konstitusional keberadaan jalur pendidikan secara informal (pendidikan di dalam keluarga) menjadi kekuatan hukum yang legal formal. Secara hak-hak kewarganegaraan sudah semestinya dilaksanakan oleh semua

${ }^{20}$ Moeloek \& Farid, Bahan Seminar...., hlm. 113-114. 
orang tua. Apalagi ketentuan-ketentuan secara teknis operasionalisasi memiliki ketetapan yuridis formal.

Dalam prakteknya, pendidikan keluarga belum sepenuhnya dilaksanakan oleh para orang tua yang memiliki anak-anak di rumah. Banyak faktor mengapa kemudian konsep pendidikan di dalam keluarga yang seharusnya telah diberikan oleh orang tua, belum optimal dipraktikkan dalam kehidupan keseharian para orang tua dalam mendidik anaknya di rumah. Menurut pemikiran penulis faktor penyebab masalah tersebut adalah:

1. Kurangnya pengetahuan dan pemahaman para orang tua tentang kedudukan peran dan fungsi serta tanggung jawab para orang tua dalam hal pendidikan anak-anak di rumah. Kekurangan pengetahuan dan pemahaman bisa disebabkan tingkat pendidikan para orang tua yang rendah, akibat ketidakmampuan dalam penyelesaian sekolah. Hal ini dapat kita jumpai terhadap banyaknya anak-anak putus sekolah, meningkatnya angka pengangguran yang tidak terdidik, serta lemahnya persaingan dalam ranah tenaga kerja.

2. Lemahnya peran sosial budaya masyarakat dalam membangun kesadaran akan pentingnya pendidikan keluarga. Keluarga sering kali mengabaikan nilai-nilai edukasi di dalam ranah rumah tangga, dengan membiarkan anak-anak bermain dan bergaul tanpa kontrol, kurangnya perhatian tatkala ia sedang berkomunikasi dengan sesamanya. Sikap apatis sebagian besar para orang tua terhadap tata krama pergaulan anak-anak di lingkungan bermain.

3. Kuatnya desakan dan tarikan pergulatan ekonomi para orang tua dalam memenuhi tuntutan dan kebutuhan keluarga. Sehingga mengabaikan peran-peran sebagai fungsi dan tugas orang tua bahkan ada yang tanpa disadari, akibat tuntutan kebutuhan ekonomi mereka (ayah dan ibu) lupa akan tanggung jawabnya sebagai orang tua. Mereka tinggalkan anak-anak tanpa perhatian, bimbingan dan pendidikan sebagaimana mestinya. Dalam banyak kasus, di depan mata kita sendiri menyaksikan banyak anak tumbuh tanpa perhatian orang tua. Bahkan dengan menghela nafas dalam-dalam kita menyaksikan anak-anak telah dijadikan alat (objek) komersialisasi bagi orang tua untuk mendapatkan penghasilan (uang) untuk memenuhi kebutuhan keluarga. 
4. Kemajuan arus teknologi informasi yang meluas turut pula mempengaruhi cara berpikir dan bertindak para orang tua. Misalnya perilaku instan dengan memberi fasilitas media yang tidak mendidik, membiarkan mengakses berbagai informasi tidak mendidik, baik melalui tayangan media televisi dan pengawasan (proteksi) yang tidak terkontrol, akibat ketidakpedulian para orang tua.

Harus diakui galaunya para stakeholder di negeri ini menyaksikan banyaknya anak-anak tidak memperoleh perhatian yang besar dari para orang tua. Akhirnya, Pemerintah melalui lembaga dan institusi yang berwenang telah mencanangkan gerakan "Pendidikan Anak Usia Dini", yang terdapat di dalam Undang-Undang Sistem Pendidikan Nasional (Sisdiknas) pada bagian ke tujuh pasal 27 ayat 5, menyebutkan "Pendidikan Anak Usia Dini pada jalur informal berbentuk pendidikan keluarga atau pendidikan yang diselenggarakan oleh lingkungan". Ayat 1 berbunyi "Pendidikan Anak Usia Dini diselenggarakan sebelum jenjang pendidikan dasar".

Kenyataan di atas, mempertegas kita para orang tua, bahwa pendidikan anak-anak hendaknya sedari awal telah diberikan oleh para orang tua. Bila memungkinkan pendidikan anak-anak tersebut bisa diberikan di saat seorang ibu mengandung sang jabang bayi. Begitu urgensinya pendidikan keluarga telah mengisyaratkan kepada para orang tua untuk sungguh-sungguh dalam menjadikan pendidikan keluarga sebagai fondasi yang kuat. Proses pendidikan anak sangat berguna untuk mengembangkan potensi yang dimiliki mereka. Sehingga anak menjadi sosok yang berkepribadian cerdas, sempurna dan unggul dalam merajut masa depan anak yang didambakan oleh semua para orang tua, masyarakat dan negara.

\section{Kesimpulan}

Keluarga adalah lembaga yang utama dan pertama bagi proses awal pendidikan anak-anak untuk mengembangkan potensi yang dimiliki seorang anak ke arah pengembangan kepribadian diri yang positif dan baik. Orang tua (ayah dan ibu) memiliki tanggung jawab yang besar dalam mendidik anak-anak dalam keluarga. Fungsi-fungsi dan peran orang tua tidak hanya sekedar memenuhi kebutuhan fisik anak berupa kebutuhan makan dan minum, pakaian, tempat tinggal tapi juga tanggung jawab orang tua jauh 
lebih penting dari itu adalah memberi perhatian, bimbingan, arahan, motivasi, dan pendidikan, serta penanaman nilai.

Besarnya tanggung jawab orang tua (ayah dan ibu) mendidik anak dalam lingkungan keluarga di dukung pula dengan teori-teori pendidikan yang dikemukakan oleh para filosof dan pemikir yang mencurahkan hidupnya untuk dunia pendidikan. Seperti Comenius, J.H. Pestolozzi, F. Frobel, Maria Montessori, AlGazali, Ki Hajar Dewantara dan Engku Muhammad Syafe'i. Konsep yang ditawarkan melalui teori-teori tersebut telah menjadi rujukan dan referensi bagi perkembangan dan pengembangan pendidikan anak-anak terutama Pendidikan Anak Usia Dini (PAUD) di Indonesia.

\section{Kepustakaan}

Abdullah, M. Imron, Pendidikan Keluarga Bagi Anak, (Cirebon: Lektur, 2003).

Soenarjo, A., al-Qur'an dan Terjemahnya, (Jakarta: Teraju, 1989).

Berns, Roberta M., Child, Family, School, Community Socialization and Support, (United State: Thomson Corporation, 2007).

Hasan, Fathiyah Sulaiman, Alam Pikiran Al-Gazali Mengenai Pendidikan dan Ilmu, (Bandung: Diponegoro, 1986).

Jalal, Fasli \& Farid Anfasa Moeloek, Bahan Seminar ISN Kayu Tanam, (2006).

Dewantara, Ki Hajar, Ilmu Pendidikan, (Yogyakarta: Taman Siswa, 1961).

Langgulung, Hasan, Manusia dan Pendidikan, (Jakarta: Pustaka al-Husna, 1986).

Mansur, Pendidikan Anak Usia Dini dalam Islam, (Yogyakarta: Pustaka Pelajar, 2005).

Patmonodewo, Soemiarti, Pendidikan Anak Prasekolah, (Jakarta: Rineka Cipta, 2003).

Sadullah, Uyoh, Pengantar Filsafat Pendidikan, (Bandung: Alfabeta, 2007).

Soemarjan, Selo, Sosiologi Suatu Pengantar, (Yogyakarta: Gajah Mada Press, 1962).

Undang-Undang Nomor 20 Tahun 2003 tentang Sistem Pendidikan Nasional. 


\title{
Akhlak Mulia dalam Pandangan Masyarakat
}

\author{
Mustopa \\ IAIN Walisongo Semarang \\ E-mail: halmar66@gmail.com
}

\begin{abstract}
This paper elaborate on views of the community on a noble character. Categorization of noble character is different in view of the public. This study used a qualitative approach which is the data derived from the literature and society. The results of this study indicate that the noble character in view of the public looks through oral and actions and it is always behaved by someone, and it is not temporary. Normative morality is embedded in the inner nature of the soul that gives rise to act with ease. Morals reflected in a person in relation to God and the community. It was influenced by heredity, environment, and both formal and non-formal education. Individually, moral goodness cause calmness and serenity in a person and make it easier to interact socially with the community.
\end{abstract}

Keywords: noble character, community

\begin{abstract}
Abstrak
Tulisan ini menguraikan pandangan masyarakat tentang akhlak mulia. Kategorisasi akhlak mulia berbeda-beda dalam pandangan masyarakat. Penelitian ini menggunakan pendekatan kualitatif yang sumber datanya berasal dari literatur dan masyarakat. Hasil kajian ini menunjukkan bahwa akhlak mulia dalam pandangan masyarakat tampak melalui lisan dan perbuatannya dan selalu ada pada seseorang, dan tidak bersifat temporer. Akhlak secara normatif merupakan sifat batin yang tertanam dalam jiwa yang memunculkan perbuatan dengan mudah. Akhlak terpantul dalam diri seseorang dalam hubungannya dengan Tuhan dan masyarakat. Hal itu dipengaruhi keturunan, lingkungan, dan pendidikan baik formal maupun nonformal. Secara individual, kebaikan akhlak menyebabkan ketenangan dan ketenteraman pada diri seseorang dan secara sosial memudahkan berinteraksi dengan masyarakat.
\end{abstract}

Kata kunci: akhlak mulia, masyarakat 


\section{A. Pendahuluan}

Misi utama diutus Rasulullah Muhammad SAW adalah untuk menyempurnakan akhlak mulia, "Sesungguhnya saya diutus untuk menyempurnakan akhlak mulia". Sebagaimana dijelaskan dalam firman-Nya (Q.S. Ibrahim/14 : 1) "Alif Lam Ra. (Ini adalah) Kitab yang Kami turunkan kepadamu (Muhammad) agar engkau mengeluarkan manusia dari kegelapan kepada cahaya terangbenderang dengan izin Tuhan". Menurut Quraish Shihab, "mengeluarkan manusia dari kegelapan kepada cahaya", artinya mengeluarkan manusia seluruhnya dari aneka gelap gulita, apapun bentuk dan jenisnya, termasuk akhlak yang tercela manusia. ${ }^{1}$

Seorang dapat dikatakan berakhlak, apabila ia mendasarkan perilakunya pada ajaran agama Islam, yang bersumber pada wahyu. Ia menunjukkan kesadaran terhadap keberadaan Tuhan di setiap saat, menyadari bahwa Tuhan mengetahui segala perbuatannya. Sehingga segala aktivitas hidupnya adalah untuk beribadah kepada Allah. Jadi, keimanan dalam Islam, pada dasarnya merupakan kesadaran untuk menjadi pribadi yang baik. ${ }^{2}$ Maka, di sinilah letak hubungan antara akhlak dan iman.

Hubungan akhlak dengan ibadah dapat dilihat dalam pengajaran prinsip-prinsip Islam beserta pengamalannya. Prinsipprinsip yang dimaksud adalah rukun Islam yang lima, dengan melaksanakan rukun tersebut, otomatis dapat mengembangkan akhlaknya. ${ }^{3}$ Dengan berpegang pada syahadah, seorang Muslim akan komit untuk taat kepada Allah. Implikasinya, ia akan menunjukkan integritas, kejujuran, amanah dan sebagainya. Begitu pula salat, seorang Muslim akan terhindar dari perbuatan keji, sederhana, ramah dan sebagainya. Implikasinya akan terlihat dalam hubungan seseorang dengan kedua orang tua, keluarga, tetangga, semua orang termasuk dengan binatang dan alam. Dengan menjalankan rukun Islam ketiga yaitu zakat, seorang Muslim akan dapat menanamkan benih-benih kebajikan, simpati dan kedermawanan untuk mengokohkan hubungan persahabatan

1 M. Quraish Shihab, Tafsir Al-Misbah, (Tangerang: Lentera Hati, 2005), jil. 7, hlm. 6 .

${ }^{2}$ Al-Gazali, Ihyä' Ulüm al-Dīn, juz 1,terj. Ismail Ya'kub, (Singapura: Pustaka Nasional, 2003), hlm. 3.

${ }^{3}$ Al-Gazali, Ihyà' Ulüm al-Dìn, juz 1, hlm. 1. 
berdasarkan cinta kasih. Selain itu, dalam puasa dan haji, dapat mendidik orang untuk bersabar, menahan diri dan disiplin diri. ${ }^{4}$

Ibadah dalam praktiknya telah memiliki ketentuan yang jelas cara melakukannya, terutama yang berhubungan dengan syarat rukun. Sehingga dapat dijadikan ukuran pada praktik ibadah yang baik dan benar. Namun, tidak demikian pada akhlak. Akhlak yang notabene merupakan sifat dari jiwa yang menimbulkan perbuatan tanpa melalui pemikiran dan pertimbangan, belum dapat diketahui dengan pasti tentang hukum perbuatannya, sebelum diadakan penelitian terhadap suatu perbuatan. Di samping itu, praktik "perbuatan" akhlak, sangat mungkin terjadi perbedaan antara satu orang dengan orang lain. Misalnya, perbedaan dalam mengukur nilai perbuatan yang baik dan buruk, dapat menyebabkan perbedaan dalam merespons keadaan yang dihadapi. Perbedaan dalam mengukur perbuatan akhlak muncul, sebab adanya perbedaan pandangan antara satu dengan yang lainnya. Sehingga akan terjadi perbedaan antara satu sama lain.

Bahasan tentang akhlak mulia lebih banyak berdasarkan kajian-kajian normatif-deduktif, menurut para ulama atau pakar, dan masih jarang adanya kajian yang berdasarkan pengalaman empirik dalam masyarakat dengan pendekatan induktif. Kajian berdasarkan pendekatan empirik-induktif tersebut, diharapkan akan dapat memudahkan sosialisasi mengenai akhlak mulia, yang notabene merupakan tujuan utama dari misi diutusnya Nabi Muhammad saw.

\section{B. Metode Penelitian}

Penelitian ini bertujuan untuk mendapatkan gambaran tentang pandangan masyarakat terhadap akhlak mulia melalui pendekatan kualitatif. Data dikumpulkan dari latar yang alami sebagai sumber data langsung. Penelitian ini diharapkan mampu menemukan, sekaligus mendeskripsikan data secara menyeluruh dan utuh, berkaitan pandangan masyarakat tentang akhlak mulia. Selain itu, penelitian ini juga diharapkan mampu membangun suatu teori secara induktif dari berbagai abstraksi data yang telah

${ }^{4}$ Hamid Fahmy Zarkasy, Peranan Masjid dalam Pendidikan Karakter (Akhlaq), (Semarang: Makalah Seminar Masjid Baiturrahman, 2011), hlm. 12. 
dikumpulkan tentang akhlak yang mulia, melalui temuan makna dalam latar yang alami oleh masyarakat.

Data yang dikumpulkan dalam penelitian ini sesuai dengan tujuan penelitian, yaitu pandangan masyarakat tentang akhlak mulia. Jenis data dalam penelitian ini dibedakan menjadi dua, yaitu data primer dan sekunder. Data primer diperoleh dalam bentuk verbal atau kata-kata atau ucapan lisan dari subjek (informan) yang berkaitan dengan pandangan masyarakat terhadap akhlak mulia. Data sekunder bersumber dari dokumen-dokumen dan bendabenda, yang digunakan sebagai pelengkap data primer, seperti literatur terkait pandangan masyarakat tentang akhlak mulia.

Sumber data dalam penelitian ini adalah manusia atau orang yang bertindak sebagai subjek atau informan kunci (key informants). Penentuan informan dalam penelitian ini didasarkan pada kriteria berikut: 1) Subjek cukup lama dan intensif menyatu dengan medan aktivitas yang menjadi sasaran penelitian. 2) Subjek masih aktif terlibat di lingkungan yang menjadi sasaran penelitian ini. 3) Subjek yang masih memiliki waktu untuk dimintai informasi oleh peneliti. Sehubungan dengan kriteria yang sesuai dengan tujuan penelitian tersebut, maka pemilihan informan peneliti dilakukan dengan memilih subjek yang dianggap cukup mewakili pandangan masyarakat. Dan peneliti memilih subjek yang dianggap menjadi tokoh di masyarakatnya.

Demi memperoleh data secara holistik dan integratif, serta memperhatikan relevansi data dengan tujuan penelitian. Maka dalam pengumpulan data penelitian menggunakan teknik studi literatur dan wawancara. Teknik studi literatur digunakan untuk mengetahui konsep akhlak mulia secara normatif. Sedangkan teknik wawancara digunakan untuk mendapatkan data yang diperlukan dalam penelitian, yaitu pandangan masyarakat tentang akhlak mulia. Teknik wawancara berupa wawancara terstandar (standardized interview), peneliti menyusun suatu daftar pertanyaan secara tertulis, dan diberikan kepada subjek penelitian sebelum dilakukan wawancara.

Menurut Bodgan dan Biklen dalam Madyo Ekosusilo, ${ }^{5}$ analisis data merupakan proses mencari dan mengatur secara

${ }^{5}$ Madyo Ekosusilo, Sistem Nilai Dalam Budaya Organisasi Sekolah pada Sekolah Unggul (Studi Multi Kasus di SMU Negeri 1, SMU Regina 
sistematis transkrip wawancara, catatan lapangan, dan bahanbahan lain yang telah dihimpun oleh peneliti. Analisis dilakukan dengan menelaah data, menata, membagi menjadi satuan-satuan yang dapat dikelola, menyintesis, mencari pola, menemukan apa yang bermakna, apa yang diteliti dan dilaporkan secara sistematis. Data merupakan deskripsi dari pertanyaan-pertanyaan seseorang tentang perspektif, pengalaman atau suatu hal, sikap, keyakinan, dan pikirannya serta petikan-petikan isi dokumen yang berkaitan dengan suatu program. ${ }^{6}$

Setelah data terkumpul, kemudian diadakan analisis data. Menurut Miles dan Huberman dalam Sugiyono bahwa analisis data terbagi menjadi beberapa tahap, yaitu: 1) data reduction, yaitu merangkum, memilih hal-hal pokok, memfokuskan hal-hal penting dari tema dan polanya serta membuang yang tidak perlu. Pada tahap awal ini, peneliti berusaha mendapatkan data berdasarkan masalah dan tujuan penelitian yang telah ditetapkan. 2) tahap data display atau penyajian data, dalam penelitian kualitatif biasanya berupa teks yang bersifat naratif, dan bisa dilengkapi dengan grafik, matrik, network dan chart. Pada tahap ini peneliti menyajikan data berkaitan dengan pandangan masyarakat tentang akhlak mulia. 3) Conclusion drawing atau verification, yakni tahap penarikan kesimpulan dan verifikasi. Pada tahap ini diharapkan peneliti sudah mampu menjawab rumusan tujuan penelitian yaitu pandangan masyarakat tentang akhlak mulia. ${ }^{7}$

\section{Konsep Akhlak Mulia}

Secara bahasa Akhlak, (Bahasa Arab: akhlāq) berarti bentuk kejadian; dalam hal ini tentu bentuk batin seseorang. ${ }^{8}$ Kata $a k h l \bar{a} q$ merupakan bentuk jama' dari kata khuluq. Dalam Kamus alMunjid, kata khuluq berarti budi pekerti, perangai, tingkah laku, atau tabiat. ${ }^{9}$ Begitu pula, dalam bahasa Yunani, pengertian khuluq

Pacis, dan SMU Al-Islam 01 Surakarta), (Disertasi: Universitas Negeri Malang, 2003), hlm. 81.

${ }^{6}$ Ekosusilo, Sistem Nilai ..., hlm. 81-82.

7 Sugiyono, Metode Penelitian Pendidikan: Pendekatan Kuantitatif, Kualitatif dan R\&D, (Bandung: Alfabeta, 2008), hlm. 247.

8 Murni Jamal, Metodik Khusus Pengajaran Agama Islam, (Jakarta: Departemen Agama, 1984), hlm. 53.

${ }^{9}$ Luis Ma'luf, Al-Munjid, (Bairut: Dar al-Masyriq, t.t.), hlm. 194. 
ini disamakan dengan kata ethicos, yang berarti adab kebiasaan, perasaan batin, kecenderungan hati untuk melakukan perbuatan. Ethicos kemudian berubah menjadi etika. ${ }^{10}$ Kata khuluq disebutkan dalam al-Qur'an Surat al-Qalam/68 ayat 4, yang artinya "Dan Sesungguhnya kamu benar-benar berbudi pekerti yang agung". Firman Allah tersebut menunjukkan bahwa kata khuluq merupakan perilaku Rasulullah Saw. yang telah menjadi kebiasaan. Menurut Quraish Shihab, kata khuluq dalam ayat tersebut jika tidak dibarengi dengan objektifnya, maka berarti budi pekerti yang luhur, tingkah laku dan watak terpuji. ${ }^{11}$

Perilaku-perilaku Rasulullah Saw. yang telah menjadi kebiasaan disebut dengan akhlāq (Indonesia: akhlak). Rasulullah Saw. diutus untuk menyempurnakan akhlak yang mulia, dan akhlak beliau adalah al-Qur'an. Beliau mengajarkan kita untuk berdoa ketika bercermin; "Allāhummā kamā hassanta khalqī, fahassin khuluqî", yang artinya ialah "Ya Allah sebagaimana telah Engkau baguskan penciptaanku ini, maka baguskan pula akhlak ini". Dalam doa tersebut terkandung maksud bahwa kita memohon kepada Allah agar diberi kemudahan untuk memperoleh akhlak yang baik. Dan pernyataan bahwa pemberian Allah kepada kita berupa penciptaan pada diri ini adalah benar-benar yang terbaik (Q.S. Al-Tin/95: 4).

Definisi akhlak dapat dirujuk dari beberapa pengertian para tokoh, seperti al-Gazali, Abdullah Darroz, Ibnu Maskawaih, dan Ahmad Amin. Menurut Imam Al-Gazali, akhlak adalah sifat yang tertanam dalam jiwa yang dapat menimbulkan perbuatanperbuatan dengan mudah tanpa melalui pemikiran dan pertimbangan. $^{12}$

Menurut Abdullah Darroz, akhlak adalah suatu kekuatan dalam kehendak yang mantap serta membawa kecenderungan terhadap pemilihan pada pihak yang benar (akhlak yang baik) dan/atau pihak yang jahat (akhlak yang buruk). ${ }^{13}$ Menurut Ahmad Amin, akhlak adalah kebiasaan kehendak, yang berarti bahwa bila kehendak itu membiasakan sesuatu maka kebiasaan tersebut

${ }_{10}$ M. Yatimin Abdullah, Studi Akhlak dalam Perspektif Al-Qur'an, (Jakarta: Amzah, 2007), hlm. 3.

${ }^{11}$ Shihab, Tafsir Al-Misbah, jil. 14, hlm. 380.

${ }^{12}$ Al-Gazali, Ihyä' Ulüm al-Dìn, hlm, 1034.

${ }^{13}$ Abdullah, Studi Akhlak ..., hlm. 4. 
disebut akhlak. ${ }^{14}$ Akan tetapi, Ahmad Amin memberikan pengertian yang lain, akhlak ialah menangnya keinginan dari beberapa keinginan manusia secara langsung dan berturut-turut. Dinamakan orang yang (berakhlak) baik adalah orang yang menguasai keinginan baik dengan langsung dan berturut-turut, sebaliknya orang yang (berakhlak) buruk ialah orang yang menguasai keinginan buruk dengan langsung dan berturut-turut. ${ }^{15}$ Sedangkan menurut Ibn Maskawaih, akhlak adalah suatu keadaan yang melekat pada jiwa manusia, yang berbuat dengan mudah, tanpa melalui pemikiran atau pertimbangan. ${ }^{16}$

Berdasarkan definisi akhlak di atas, penulis menganggap pengertian akhlak menurut al-Gazali memiliki kesamaan dengan Ibn Maskawaih. Keduanya sama-sama menyebutkan akhlak sebagai keadaan yang melekat pada jiwa, yang menjadikan manusia dapat berbuat dengan mudah, tanpa melalui pemikiran dan pertimbangan. Adapun pengertian akhlak menurut Ahmad Amin bersifat lebih umum, yakni akhlak ialah kehendak yang dibiasakan. Sehingga kalau kehendaknya membiasakan perbuatan, dan perbuatannya menjadi terbiasa, maka dinamakan akhlak pula.

Dilihat dari segi redaksinya, pengertian-pengertian tersebut memiliki kemiripan, antara definisi dari kedua tokoh di atas (alGazali dan Ibn Maskawih) dan Ahmad Amin. Namun, perbedaannya ialah dalam Ahmad Amin tidak menyebutkan keadaan perbuatan yang muncul, apakah melalui pemikiran dan pertimbangan atau tidak. Hanya saja Amin, juga mengatakan bahwa akhlak ialah menangnya keinginan dari beberapa keinginan manusia dengan langsung dan berturut-turut. Kata keinginan manusia dengan langsung dan berturut-turut, memberikan pemahaman bahwa perbuatan tersebut telah menjadi terbiasa. Adapun pengertian yang lain, pasti memiliki kesamaan dengan pengertian yang dikemukakan oleh ketiga tokoh di atas. Selanjutnya, penulis menggunakan pengertian akhlak menurut Ibn Maskawaih dan al-Gazali. Akhlak adalah sifat yang tertanam dalam jiwa yang melahirkan perbuatan dengan mudah tanpa melalui pemikiran dan pertimbangan. Maksud dari sifat yang

${ }^{14}$ Ahmad Amin, Etika (Ilmu Akhlak), (Jakarta: Bulan Bintang, 1993), hlm. 62 .

${ }^{15}$ Amin, Etika ..., hlm. 62.

${ }^{16}$ Ibn Maskawaih, Kitab Tahżib al-Akhlaq wa Tațir al-A'raq, (Mesir: al-Husainiyah al-Misriyah,1329 H), hlm. 25. 
tertanam dalam jiwa yakni salah satunya berupa kehendak, sebagaimana menurut Ahmad Amin.

Konsep akhlak al-Gazali memiliki kesamaan dengan konsep Ibnu Maskawaih, terutama tentang pengertian akhlak. Konsep akhlak tersebut dapat dilihat dari karya keduanya, yaitu al-Gazali dalam Ihyä, Ulum al-Din dan Ibnu Maskawaih dalam Kitab Tahżib al-Akhlāq wa Tathir al-A'raq. Kesamaan konsep keduanya tentang akhlak, menarik untuk ditanggapi, siapa yang merujuk pendapat siapa. Apakah Maskawaih merujuk pendapat al-Gazali, ataukah sebaliknya? Jika dilihat dari riwayat hidup kedua tokoh tersebut, Ibnu Maskawaih lahir lebih dahulu daripada al-Gazali. Menurut Abu Ali, seorang pengkaji dan sejarawan, Ibnu Maskawaih lahir di Ray, menetap di Isfahan, dan wafat di kota tersebut pada tahun 421 H./1030 M. ${ }^{17}$ Sedangkan al-Gazali, yang lahir di kota Thusia (Toos) Khurasan tahun 1058 M./450 H, dan wafat tahun $1111 \mathrm{M} . / 505 \mathrm{H} .{ }^{18}$ Maka jika dilihat dari sejarah hidup, al-Gazali lahir setelah 28 tahun dari wafatnya Ibnu Maskawaih.

Dengan demikian, maka al-Gazali lah yang merujuk pendapat Ibnu Maskawaih. Ibnu al-Khatib, dalam kata pengantar penerbitan buku Kitab Tahżib al-Akhläq wa Tathir al-A'raq, ia mengakui bahwa setelah membaca buku karya Ibn Maskawaih, mengira bahwa Ibnu Maskawaih banyak merujuk pendapat al-Gazali. ${ }^{19}$ Hal ini dikarenakan ia menemukan banyak kesamaan dengan isi kitab Ihyā' Ulum al-Din karya al-Gazali. Tetapi setelah melihat sejarah hidup kedua tokoh tersebut, ternyata Maskawaih lebih dahulu lahir daripada al-Gazali, bahkan beliau lahir jauh setelah Ibn Maskawaih wafat. Berdasarkan realitas tersebut, Ibnu alKhatib mengatakan, al-Gazalilah yang merujuk pada Ibn Maskawaih.

Berdasarkan pengertian akhlak di atas, dapat dipahami bahwa akhlak memiliki beberapa indikator, yaitu: Pertama, pada dasarnya akhlak adalah perbuatan lahiriah yang menunjukkan keadaan jiwa. Perbuatan lahiriah yang ditampilkan merupakan tanda atau gejala adanya akhlak. Sebab, keadaan jiwa tidak dapat dibuktikan kecuali dengan melihat gejala yang dilahirkan. Akhlak merupakan sifat dalam diri seseorang yang mendorong lahirnya perbuatan-

${ }^{17}$ Ibnu Maskawaih, Menuju Kesempurnaan Akhlak, terj Helmi Hidayat, (Bandung: Mizan, 1997), hlm. 29.

${ }^{18}$ Al-Gazali, Ihya', Ulüm al-Dīn, juz I, hlm. 25.

${ }^{19}$ Maskawaih, Menuju Kesempurnaan Akhlak ..., hlm. 26. 
perbuatan, dan jika sifat tersebut dibiasakan maka akan melahirkan perbuatan dengan mudah tanpa melalui pertimbangan dan pemikiran, dan perbuatan tersebut akan menjadi kebiasaan.

Oleh karena itu, untuk mengetahui akhlak seseorang, dapat dilihat dari perbuatan yang ditampilkan. Sebab, perbuatan yang terlihat sebenarnya merupakan ekspresi dari sifat batinnya. Sehingga kalau perbuatan yang ditampilkan adalah baik, maka menunjukkan sifat yang tertanam dalam jiwa adalah baik. Begitu juga sebaliknya, jika perbuatan yang ditampilkan adalah perbuatan yang buruk, maka hal ini menunjukkan bahwa sifat dalam jiwa pun juga buruk. Pertanyaannya ialah apakah setiap perbuatan yang ditampilkan seseorang pasti menunjukkan sifat batin yang asli atau akhlak seseorang? Jawabannya, bahwa tidak selalu perbuatan yang ditampilkan dapat menunjukkan keadaan akhlak seseorang, karena harus dilihat cara munculnya perbuatan tersebut, apakah munculnya itu secara mudah, ataukah karena telah melalui pemikiran dan pertimbangan.

Indikator yang kedua, yakni perbuatan akhlak tersebut ialah secara mudah dan tanpa melalui pemikiran dan pertimbangan. Kalau suatu perbuatan itu muncul melalui pemikiran dan pertimbangan terlebih dahulu. Sehingga tidak akan mudah muncul, walaupun perbuatan tersebut bernilai baik, tetapi belum dapat dikatakan sebagai akhlak, karena masih dalam proses (perbuatan) akhlak.

Ketiga, Perbuatan yang dibiasakan atau telah menjadi kebiasaan. Perbuatan yang menunjukkan adanya akhlak adalah perbuatan yang telah menjadi kebiasaan. Perbuatan yang belum dibiasakan tidak dikatakan sebagai akhlak tapi masih dalam 'proses' (perbuatan) akhlak. Menurut penulis, perbuatan yang dilakukan secara terus-menerus akan menjadi perbuatan yang terbiasa dan akan muncul dengan mudah. Dengan alasan, bahwa akhlak merupakan kebiasaan kehendak, sebagaimana kata Ahmad Amin. ${ }^{20}$ Kehendak untuk melakukan perbuatan itu, jika dibiasakan secara terus-menerus akan menjadi perbuatan yang terbiasa dengan mudah. Oleh sebab itu, perbuatan yang terbiasa berawal dari perbuatan yang dilakukan secara terus-menerus.

Di samping itu, penulis mengutip pengertian akhlak menurut al-Gazali, akhlak adalah sifat yang tertanam dalam jiwa yang

${ }^{20}$ Ahmad Amin, Etika ..., hlm. 62. 
menimbulkan perbuatan-perbuatan dengan mudah tanpa melalui pemikiran dan pertimbangan. ${ }^{21}$ Menurut penulis, timbulnya perbuatan dengan mudah tanpa melalui pemikiran dan pertimbangan tersebut, dapat terjadi karena perbuatan tersebut telah terbiasa dilakukan, melalui proses secara kontinu, dan pada akhirnya perbuatan itu menjadi mudah dilakukan. Oleh karena itu, perbuatan yang telah terbiasa dilakukan, maka akan muncul secara mudah bilamana dibutuhkan pada kesempatan lain, seolah-olah tanpa melalui pemikiran dan pertimbangan.

Keempat. Perbuatan akhlak dilakukan berdasarkan kesadaran. Munculnya perbuatan dengan mudah tanpa melalui pemikiran dan pertimbangan, bukan berarti perbuatan-perbuatan itu dilakukan tanpa sadar, tetapi tetap berdasarkan kesadaran. ${ }^{22}$ Dengan alasan bahwa perbuatan yang terbiasa dilakukan seseorang secara terusmenerus, akan menjadikan seseorang melakukan dengan mudah, sehingga karena kemudahan tersebut 'seolah-olah' dilakukan tanpa melalui pemikiran dan pertimbangan.

Penulis mengatakan 'seolah-olah', sebab pada dasarnya seseorang melakukan perbuatan pasti sebelumnya telah dipertimbangkan dan dipikirkan. Inilah yang membedakan perbuatan yang dilakukan oleh seseorang dengan binatang. Namun, karena telah terbiasa melakukan perbuatan tersebut secara terus-menerus, maka menjadi mudah dikerjakan, tanpa melalui pemikiran dan pertimbangan.

Sehingga dapat diambil kesimpulan bahwa akhlak sebenarnya merupakan bentuk batin seseorang, di mana untuk mengetahuinya dapat dilihat dari perilaku-perilaku yang ditampilkan, dan proses munculnya perilaku, telah dijelaskan di atas. Sehingga dalam menilai akhlak seseorang, dapat dilihat dari tingkah laku yang ditampilkan. Selain itu dari segi nilai, bentuk batin, ada yang baik dan buruk, serta terpuji dan tercela. Norma baik dan buruk (terpuji dan tercela) bagi orang beriman yang meyakini kebenaran ajaran agama Islam, merupakan ajaran agama sendiri. Bila tingkah laku yang ditimbulkan oleh akhlak itu sesuai dengan ajaran agama Islam, itu dianggap baik, dan apabila bertentangan, maka dianggap buruk atau tercela. ${ }^{23}$ Jadi, baik dan buruknya akhlak dapat dilihat

${ }^{21}$ Al-Gazali, Ihyā' 'Ulüm al-Dìn, hlm, 1034.

${ }^{22}$ Al-Gazali, Ihyā' 'Ulüm al-Dìn, hlm, 1034.

${ }^{23}$ Zakiah Daradjat, Metodik Khusus Pengajaran Agama Islam, (Jakarta: Bumi Aksara, 2008), hlm. 68. 
dari kesesuaian dengan ajaran Islam. Maka dari itu, akhlak dibagi menjadi dua, yaitu akhlak yang baik (mulia), disebut akhlak mahmüdah dan akhlak yang buruk (tercela), disebut akhlak mażmümah.

Adapun objek akhlak dalam Islam meliputi berbagai aspek hubungan. Menurut Zakiah Daradjat, orang berbuat dalam rangka hubungannya dengan Tuhan, dengan dirinya sendiri, dengan sesama manusia, dengan binatang, dan dengan makhluk lainnya. ${ }^{24}$ Sementara itu, Wahbah az-Zuhaili membagi akhlak muslim menjadi tiga, yaitu hubungan manusia dengan Tuhan, hubungan manusia dengan sesama dan alam semesta, dan hubungan manusia dengan masyarakat. ${ }^{25}$

\section{Pandangan Masyarakat tentang Akhlak Mulia}

Kajian tentang akhlak mulia didasarkan pada pendekatan normatif, dengan melihat akhlak berdasarkan dalil-dalil dan pemikiran para ahli dalam bidangnya. Selanjutnya, dalam pembahasan ini akan mengulas akhlak mulia secara pendekatan induktif berdasarkan pandangan masyarakat. Hal ini menjadi penting agar akhlak dapat mudah disosialisasikan dan dilaksanakan sesuai dengan perkembangan zaman. Sehingga penulis akan memaparkan pandangan masyarakat terhadap akhlak yang mulia.

Paparan berdasarkan hasil wawancara dengan tiga responden yang dipandang sebagai tokoh di masyarakat. Tujuan wawancara adalah untuk mendapatkan data tentang pandangan masyarakat terhadap akhlak mulia yang meliputi: Pengertian akhlak mulia, tanda-tanda akhlak mulia pada seseorang, tanda-tanda orang yang tidak memiliki akhlak mulia, faktor-faktor yang menyebabkan adanya akhlak mulia, dan dampak akhlak mulia pada diri seseorang baik secara individu maupun sosial.

1. Pengertian Akhlak Mulia

Pengertian akhlak mulia menurut pandangan masyarakat sangat bervariasi dan beragam, dengan pengertian akhlak secara normatif oleh para ulama. Dari ketiga responden yang penulis wawancarai tentang akhlak mulia, mereka

${ }^{24}$ Zakiah Daradjat, Metodik Khusus Pengajaran Agama Islam..., hlm. 71.

${ }^{25}$ Wahbah Az-Zuhaili, Ensiklopedi Akhlak Muslim (Berakhlak dalam Bermasyarakat, terj. Abdul Azis, (Jakarta: Noura Books, 2014), hlm. xiv. 
memberikan penjelasan yang berbeda-beda. Untuk lebih detailnya berikut ini penulis paparkan hasil wawancara tentang pengertian akhlak mulia.

a. H. Sutaryo, SE., akhlak mulia, yaitu sifat yang mencakup semua jenis kebaikan, ketaatan dan amal. Ia memberikan contoh akhlak mulia, seperti sikap yang santun, sopan, tutur kata lembut penuh kasih sayang, tidak marah, bisa menjadi teladan yang baik, dan taat beribadah. ${ }^{26}$

b. H. Supadi, SH., pengertian akhlak mulia ialah perilaku rutinitas yang baik, yang terpuji dan bukan temporer, yang menjadi tuntunan agama maupun sosial kemasyarakatan. Ia menjelaskan bahwa akhlak mulia dasarnya adalah alQur'an dan Hadits. ${ }^{27}$

c. H. Nasucha, SE., pengertian akhlak yang mulia adalah perilaku baik seseorang berdasarkan iman yang kuat, baik kepada sesama muslim maupun kepada nonmuslim. Ia memberikan contoh akhlak mulia adalah berbuat jujur. ${ }^{28}$

2. Tanda-tanda adanya akhlak mulia

Pandangan masyarakat tentang tanda-tanda adanya akhlak mulia pada diri seseorang dapat dilihat dari hasil wawancara dengan responden:

a. H. Sutaryo, SE., menjelaskan tanda-tanda adanya akhlak mulia pada seseorang, yaitu; 1) baik kepada siapa saja, kenal atau pun tidak, 2) menahan nafsunya untuk berbuat jahat baik lisan maupun tangan, 3) bersabar ketika dizalimi orang lain, 4) tidak mudah tersinggung.

b. H. Supadi, SH., menjelaskan tanda-tanda adanya akhlak mulia pada seseorang, yaitu; 1) perilakunya diterima masyarakat umum, 2) setiap bertindak mempertimbangkan segi positif dan negatifnya, 3)

${ }^{26}$ Wawancara dilaksanakan pada tanggal 30 Juni 2014. H. Sutaryo, SE ialah Ketua Yayasan Miftahul Mubarok. Beliau Pegawai PNS Dinas Pariwisata Jawa Tengah.

${ }^{27}$ Wawancara pada tanggal 30 Juni 2014 dengan H. Supadi, SH. Beliau adalah Ketua Majlis Taklim Asmaul Husna Masjid Al-Mubarok, dan beliau adalah Pegawai PNS Sekretarias Dewan Propinsi Jawa Tengah.

${ }^{28}$ Wawacara pada tanggal 30 Juni 2014 dengan H. Nasucha, SE. Beliau Sekretaris Takmir Masjid Al-Mubarok Tlogosari, dan Pensiunan PLN Distribusi Jawa Tengah dan DIY. 
berbicara dan berbuat selalu berpedoman pada aturan, baik aturan agama, pemerintah, maupun masyarakat.

c. Sedangkan H. Nasucha, SE., menjelaskan tanda-tanda adanya akhlak mulia pada seseorang yaitu; 1) seseorang senang melakukan amal ibadah baik yang sunah maupun yang wajib, 2) senang melakukan hubungan yang baik dengan sesama manusia.

3. Tanda-tanda seseorang yang tidak memiliki akhlak mulia

Dalam pandangan masyarakat, tanda-tanda orang yang tidak memiliki akhlak mulia adalah;

a. Menurut H. Sutaryo, SE., menjelaskan; 1) bersikap menghalalkan cara untuk meraih sesuatu, 2) tidak kenal aturan, 3) tidak peduli dengan aturan yang ada, 4) mudah mengabaikan amal ibadah, e) selalu mengajak ke arah yang negatif pada siapapun.

b. Menurut H. Supadi,SH., menjelaskan tanda seseorang yang tidak memiliki akhlak mulia, yaitu; 1) senang bergaul dengan orang yang buruk perilakunya, 2) mudah melanggar aturan yang ada, 3) tidak memperhatikan kepentingan orang lain, 4) tidak mempedulikan aturan, baik aturan agama, pemerintah maupun orang lain.

c. Sedangkan menurut H. Nasucha, SE. menjelaskan tandatanda orang yang tidak memiliki akhlak mulia ialah; a) tidak punya rasa malu, b) menunjukkan sikap yang baik di muka umum, c) mudah melakukan perbuatan yang bertentangan dengan norma agama dan sosial, d) banyak berbicara tapi sedikit berbuat.

4. Faktor-faktor adanya akhlak mulia

Dalam pandangan masyarakat faktor-faktor adanya akhlak mulia adalah sebagai berikut;

a. Menurut H. Sutaryo, SE., menjelaskan faktor yang menyebabkan adanya akhlak mulia; 1) keturunan, 2) lingkungan pergaulan sejak kecil, 3) pembawaan 4) ilmu pengetahuan.

b. Menurut H. Supadi, SH., faktor yang menyebabkan adanya akhlak yang mulia ialah; 1) lingkungan keluarga, 2) pendidikan formal dan nonformal, 3) lingkungan masyarakat, 4) keturunan, dan 5) rutinitas ibadah. 
c. Sedangkan H. Nasucha, SE., menjelaskan faktor yang menyebabkan adanya akhlak mulia adalah; 1) kebiasaan melaksanakan amar ma'rüf nahi munkar, 2) kebiasaan beramal saleh, 3) membiasakan menghindari tingkah laku tercela.

5. Pengaruh akhlak mulia bagi seseorang.

Pengaruh akhlak mulia terhadap seseorang menurut pandangan masyarakat dapat dilihat dari hasil wawancara dengan responden, yaitu;

a. H. Sutaryo, SE. menjelaskan bahwa pengaruh akhlak mulia bagi individu ialah; a) jiwanya tenang, b) mendatangkan kebahagiaan dalam kesederhanaan, c) tidak stres, d) tidak khawatir, e) tidak memiliki rasa takut sekalipun dari segi ekonomi pas-pasan, f) sudah merasakan surga di dunia.

b. Sedangkan secara sosial, menurut H. Sutaryo, SE., pengaruh adanya akhlak mulia bagi seseorang ialah; a) di tempat kerja bisa kondusif, tidak ada rasa iri (hasad), dan tidak saling menjatuhkan, b) di lingkungan masyarakatnya bisa jadi teladan, dapat memfasilitasi, memberi jalan keluar, menciptakan kerukunan, tidak menimbulkan konflik, dan punya toleransi yang tinggi, c) dapat mempengaruhi karakter orang lain ke arah yang lebih baik, dan d) dapat mempengaruhi lingkungan menjadi lebih baik.

c. Sedangkan menurut H. Supadi, SH., bahwa pengaruh adanya akhlak mulia secara individu adalah; a) selalu berperilaku baik seperti jujur dan pikiran yang positif, b) dalam berbuat selalu mempertimbangkan manfaat dan madaratnya. Adapun secara sosial, pengaruh akhlak mulia bagi seseorang ialah; a) orang yang berakhlak mulia sangat dibutuhkan masyarakat terutama dalam keteladanan dan kepemimpinannya, b) masyarakat merasa senang kepadanya, c) memiliki tanggung jawab yang besar baik dalam keluarga, lingkungan kerja, maupun masyarakat.

d. Menurut H. Nasucha, SE., menjelaskan bahwa pengaruh akhlak mulia pada seseorang secara individu adalah; a) ibadahnya teratur, b) imannya terpelihara. Sedangkan 
secara sosial orang yang memiliki akhlak mulia maka tingkah lakunya selalu baik.

\section{E. Pembahasan}

1. Pengertian akhlak mulia.

Pengertian akhlak mulia menurut pandangan masyarakat menekankan pada perbuatan yang tampak secara lahiriah dan perbuatan yang dilakukan secara terus menerus, serta tidak temporer. Kemudian perilaku yang tampak dan terus menerus tersebut tidak dibedakan antara perbuatan akhlak dengan ibadah dan keimanan. Sehingga akhlak mulia menurut masyarakat adalah tingkah laku yang terpuji, yang baik dan dapat dilihat dari perbuatan sehari-hari, baik dalam hubungannya dengan ibadah maupun keimanan.

Di antara akhlak mulia adalah sikap yang santun, sopan, tutur kata lembut penuh kasih sayang, tidak marah, bisa menjadi teladan yang baik, taat beribadah, dan berbuat jujur. Adapun sumber akhlak adalah tuntunan al-Qur'an dan Hadis. Masyarakat melihat akhlak dari perbuatan yang tampak ditampilkan, melalui perkataan dan perbuatan, namun tidak melihat dari segi hakikat. Atau mereka baru mengungkapkan buah dari akhlak, itu juga masih sangat terbatas belum pada buah akhlak yang lengkap. Imam al-Gazali pun melihat ketika beliau menyusun konsep tentang akhlak.

Al-Gazali mencontohkannya, seperti kata Hasan Basri: "Kebagusan akhlak itu manis, memberi kelebihan dan mencegah kesakitan." ${ }^{29}$ dan Al-Wasiti berkata: "Akhlak yang bagus adalah tidak bertengkar dengan orang dan orang tiada bertengkar dengan dia, karena ma'rifatnya kepada Allah". Syaikh al-Kirmani berkata: "Akhlak yang baik ialah mencegah yang menyakitkan dan menanggung kesulitan". Sebagian dari mereka, kata al-Gazali, mengatakan: "orang yang berakhlak ialah yang dekat dengan manusia (karena bagus pergaulannya) dan asing tentang sesuatu di antara manusia itu (tiada rapat berhubungan)." ${ }^{30}$. Dan masih banyak lagi contoh yang dikemukakan al-Gazali, yang pada intinya, bahwa masyarakat bersamaan mengartikan dari segi perilaku

\footnotetext{
${ }^{29}$ Al-Gazali, Ihyà', 'Ulüm al-Dìn ..., hlm. 1033.

${ }^{30}$ Al-Gazali, Ihyà', 'Ulüm al-Dīn ...,hlm. 1033.
} 
yang dapat ditampilkan dan belum pada pengertian hakikatnya.

Hal tersebut diakui oleh al-Gazali, bahwa pengertian akhlak seperti itu (tersebut di atas) adalah banyak. Yaitu mengemukakan buah (hasil) dari kebagusan akhlak. Tidak dari kebagusan akhlak itu sendiri. Kemudian, tidak pula meliputi dengan semua buah itu. Dan mengungkapkan yang tertutup dari hakikat itu adalah lebih utama daripada menyalinkan kata-kata yang bermacam-macam itu. ${ }^{31}$

Akhlak mulia dalam pandangan masyarakat yang dilihat dari segi buah yang ditampilkan adalah sesuatu yang wajar. Akhlak (dalam pengertian hakikatnya) memiliki hubungan yang sangat erat dengan perbuatan lahiriah yang tampak, demikian sebaliknya perbuatan lahiriah dapat menunjukkan batinnya. Dan hal yang demikian diakui oleh al-Gazali, dan beliau mengatakan: "Maka jiwa yang terlihat dengan mata hati itu lebih besar nilainya, dibandingkan dengan tubuh yang terlihat dengan mata kepala. Oleh sebab itu, urusan jiwa diagungkan oleh Allah swt., dengan disandarkannya kepadaNya". ${ }^{32}$ Sebagaimana tertera dalam (Q.S. Säd: 71-72), Allah memberitahukan, bahwa jasad (tubuh) itu dihubungkan kepada tanah, sedang ruh (jiwa) dihubungkan kepada Tuhan

2. Tanda-tanda adanya akhlak mulia pada seseorang.

Menurut pandangan masyarakat, tanda-tanda adanya akhlak mulia pada seseorang dapat dilihat dari perilaku yang ditampilkan, yaitu perilaku yang baik. Perilaku baik tersebut berhubungan dengan ibadah dan muamalah dengan orang lain, serta cara melakukannya. Pandangan masyarakat tentang tanda akhlak mulia tersebut, sama dengan ketika mereka mengartikan pengertian akhlak, yaitu dilihat dari perbuatan yang tampak. Menurut penulis, hal ini sangat wajar, mengingat persoalan tanda adalah sesuatu yang dapat dibuktikan. Maka mereka mengukur itu dari perilaku yang dapat terlihat. Namun, mereka belum dapat membedakan antara perilaku ibadah dengan perilaku akhlak. Begitu juga penulis memaklumi, karena akhlak dalam prakteknya juga tidak dapat dipisahkan dengan perbuatan ibadah. Dalam

\footnotetext{
${ }^{31}$ Al-Gazali, Ihyà', 'Ulüm al-Dìn ...,hlm. 1034.

${ }^{32}$ Al-Gazali, Ihya', 'Ulüm al-Dìn ...,hlm. 1034.
} 
pembagiannya, terdapat akhlak kepada Allah yang dapat dibuktikan dengan praktik ibadah. Seharusnya praktik ibadah hendaknya dapat membuahkan akhlak yang mulia.

Pandangan masyarakat tentang tanda-tanda adanya akhlak mulia adalah sebagai berikut; a) baik kepada siapapun, kenal atau tidak, b) tidak berbuat jahat baik lisan maupun tangan, c) bersabar ketika dizalimi orang lain, d) tidak mudah tersinggung. e) perilakunya diterima masyarakat umum, f) setiap bertindak mempertimbangkan segi positif dan negatifnya, g) berbicara dan berbuat selalu berpedoman pada aturan, baik aturan agama, pemerintah, maupun masyarakat, dan h) senang melakukan ibadah sunah dan wajib.

Jadi, tanda seseorang memiliki akhlak mulia adalah tercermin dari sikap perilakunya yang baik dalam pergaulan dengan orang lain, baik perkataan maupun perbuatannya, dan keberadaannya diterima oleh lingkungan. Di samping itu, rajin menjalankan ibadah sebagai bentuk hubungan baik dengan Tuhannya.

3. Tanda-tanda tidak adanya akhlak mulia pada seseorang.

Berdasarkan pandangan masyarakat juga dapat dilihat dari perilaku yang ditampilkan. yaitu; a) bersikap menghalalkan cara untuk meraih sesuatu, b) tidak peduli dengan aturan yang ada, baik agama, pemerintah maupun masyarakat, c) mudah mengabaikan amal ibadah, d) selalu mengajak berbuat ke arah yang negatif pada siapapun, e) bergaul dengan orang yang buruk perilakunya, f) tidak memperhatikan kepentingan orang lain, g) tidak punya rasa malu melakukan perbuatan jelek, h) menunjukkan sikap yang baik di muka umum, i) mudah melakukan perbuatan yang bertentangan dengan norma agama dan sosial, dan j) banyak berbicara tapi sedikit berbuat.

Pandangan masyarakat terhadap akhlak pada seseorang, bahwa akhlak yang baik tidak akan dapat berada pada keadaan akhlak yang buruk. Jika seseorang memiliki akhlak yang baik, maka akhlak yang buruk akan berkurang, Begitu pula sebaliknya. Hal tersebut dapat dilihat dari pandangan masyarakat bahwa seluruh perilaku yang tidak berada pada tanda-tanda adanya akhlak mulia itu termasuk tanda-tanda tidak adanya akhlak mulia pada seseorang.

4. Faktor-faktor adanya akhlak mulia. 
Menurut pandangan masyarakat bahwa faktor-faktor adanya akhlak mulia pada seseorang adalah; a) keturunan, b) lingkungan keluarga dan masyarakat, c) pembawaan d) pendidikan formal dan nonformal, e) rutinitas ibadah, f) kebiasaan-kebiasaan, seperti melaksanakan amr ma'rüf nahy munkar, beramal saleh, dan menghindari tingkah laku tercela.

Masyarakat masih menganggap bahwa keturunan menjadi faktor yang sangat berpengaruh terhadap terbentuknya akhlak mulia. Sehingga anak yang dilahirkan dari orang tua yang saleh kemungkinan besar anak akan tumbuh dan berkembang menjadi anak yang saleh juga. Pandangan masyarakat tersebut adalah pandangan pada umumnya dan yang semestinya, tetapi dalam kenyataan tidak selalu demikian. Banyak contoh pula, orang tua yang saleh tetapi anaknya tidak saleh, dikarenakan pergaulan yang tidak mendukung. Demikian pula faktor pembawaan, bagi masyarakat dikatakan dapat mempengaruhi akhlak pula.

Adapun faktor yang lainnya, menurut masyarakat ialah; lingkungan keluarga dan masyarakat, pendidikan, pembiasaan, dan rutinitas menjalankan ibadah merupakan faktor yang sangat menentukan terbentuknya akhlak yang baik. Menurut penulis, pandangan tersebut merupakan pandangan yang positif, mengingat bahwa manusia adalah makhluk sosial yang kehidupannya tidak akan lepas dari orang lain, dan perilaku seseorang merupakan indikasi adanya proses interaksi (belajar) dengan lingkungan.

5. Pengaruh akhlak mulia bagi seseorang

Seseorang yang memiliki akhlak mulia akan berpengaruh pada perilakunya. Secara tidak langsung mereka memandang bahwa akhlak mulia adalah sifat baik yang telah tertanam pada diri seseorang. Jika seseorang telah memiliki akhlak yang baik, maka akan melahirkan perilaku yang baik dalam segala bidang dan menjadikan hidupnya tenang dan tenteram. Pengaruh akhlak baik itu dapat dilihat secara individual maupun sosial. Secara individual akhlak yang baik akan menjadikan seseorang: (a) jiwanya tenang, (b) merasakan kebahagiaan dalam kesederhanaan, (c) tidak stres, (d) tidak khawatir, (e) tidak memiliki rasa takut sekalipun dari segi ekonomi pas-pasan, (f) sudah merasakan surga di dunia. Sedangkan secara sosial orang yang memiliki akhlak mulia, 
akan merasakan keadaan; (a) di tempat kerja bisa kondusif, tidak ada rasa iri (hasad) dan tidak saling menjatuhkan, (b) di lingkungan masyarakatnya bisa jadi teladan, dapat memfasilitasi, memberi jalan keluar, menciptakan kerukunan, (c) tidak menimbulkan konflik dan punya toleransi yang tinggi, (d) dapat mempengaruhi karakter orang lain ke arah yang lebih baik, (e) dapat mempengaruhi lingkungan menjadi lebih baik, (f) berpikir positif (positive thinking), (g) dalam berbuat selalu mempertimbangkan manfaat dan madaratnya, (h) menjadi teladan dalam masyarakatnya, (i) disenangi oleh masyarakat, dan (j) memiliki tanggung jawab yang besar baik dalam keluarga, lingkungan kerja, maupun masyarakat.

\section{F. Penutup}

Pandangan masyarakat tentang akhlak mulia bahwa akhlak mulia dimaksudkan sebagai perilaku yang baik yang tampak melalui lisan dan perbuatan, serta selalu ada pada diri seseorang, dan tidak temporer. Tanda-tanda adanya akhlak mulia pada diri seseorang dapat dilihat dari perilaku sehari-harinya berkaitan hubungan dengan diri sendiri, Tuhan maupun masyarakat. Perilaku mereka selalu ingin berbuat kebaikan. Sebaliknya tandatanda orang yang tidak memiliki akhlak yang mulia kecenderungannya selalu berbuat kejelekan dan tidak segan-segan melanggar aturan. Faktor adanya akhlak mulia adalah keturunan, lingkungan, dan pendidikan baik formal maupun nonformal. Pengaruh adanya akhlak mulia pada seseorang, secara individu akan membawa ketenangan dan ketenteraman. Sedangkan secara sosial ia akan diterima oleh masyarakatnya dan mudah menyesuaikan diri dengan masyarakat.

\section{Kepustakaan}

Abdullah, M. Yatimin, Studi Akhlak dalam Perspektif Al-Quran, (Jakarta: Amzah, 2007).

Amin, Ahmad, Etika (Ilmu Akhlak), (Jakarta: Bulan Bintang, 1993).

Asmaran As, Pengantar Studi Akhlak, (Jakarta: Raja Grafindo Persada, 2002).

'Atha, Muhammad Abdul Qadir Ahmad, Makärim al-Akhlaq, (Beirut: Dar al-Kutub al-Ilmiyah, 1989). 
Al-Zuhaili, Wahbah, Ensiklopedi Akhlak Muslim: Berakhlak dalam Bermasyarakat, terj. Abdul AQzis, (Jakarta: Noura Books, 2014).

Daradjat, Zakiah, Metodik Khusus Pengajaran Agama Islam, (Jakarta: Bumi Aksara, 2008).

Ekosusilo, Madyo, Sistem Nilai Dalam Budaya Organisasi Sekolah pada Sekolah Unggul (Studi Multi Kasus di SMU Negeri 1, SMU Regina Pacis, dan SMU al-Islam 01 Surakarta), (Malang: Disertasi Universitas Negeri Malang, 2003).

Ghazali, Imam, Ihya' Ulumiddin, terj. Ismail Ya'kub, (Singapura : Pustaka Nasional, 2003).

Ibn Maskawaih, Abū Ali Ahmad bin Muhammad al-Ma'rūf, Kitāb Tahz̧dib al-Akhlāq wa Tathhïr al-A'raq, (Mesir: AlHusainiyah al-Misriyah, 1329 H.).

Muhni, Djuretna A. Imam, Moral \& Religi, (Yogyakarta: Kanisius. 1994).

Murni Djamal, Metodik Khusus Pengajaran Agama Islam, (Jakarta: Departemen Agama, 1984).

Quasem, M. Abul. Kamil, Etika Al-Ghazali: Etika Majemuk dalam Islam, terj. J. Mahyudin, (Bandung: Pustaka, 1988).

Rakhmat, Jalaluddin, Dahulukan Akhlak di Atas Fiqih, (Bandung: Mizan, 2007).

Shihab, M. Quraish, Tafsir al-Misbah, (Tangerang: Lentera Hati. 2005).

Suseno, Franz Magnis, Etika Dasar: Masalah-masalah Pokok Filsafat Moral, (Yogyakarta: Kanisius, 1987).

Zarkasyi, Hamid Fahmy, Peranan Masjid dalam Pendidikan Karakter (Akhlaq), (Semarang: Makalah Seminar, Masjid Baiturrahman, 2011).

Zuchdi, Darmiyati, Model Pendidikan Karakter Terintegrasi dalam Pembelajaran dan Pengembangan Kultur Sekolah, (Yogyakarta: UNY Press, 2011). 


\title{
Sekolah Alam: Paradigma Baru Pendidikan Islam Humanis
}

\author{
Rohinah \\ UIN Sunan Kalijaga Yogyakarta \\ Email: rohinah80@yahoo.com
}

\begin{abstract}
This paper describes a new paradigm of Islamic education in the perspective of humanism based on nature school model. This school model has three specific aspects, namely: natural as learning space, nature as media and teaching materials, and natural as learning objects. It is a creativity in building a humanist paradigm of Islamic education. The education system emphasizes awareness to encourage the process of dialogue between teachers and students. Dialogical process can bring an attitude of humility and affection that is open to criticism from the learners. Learners are required critical and questioned again about the unknown by the teacher. This kind of learning led to a harmonious communication between all parties. School of Natural allow the emergence of awareness. This school gives the freedom to create, explore and discover potential, and find the knowledge based on experiences from the world of reality.
\end{abstract}

Keywords: Islamic education, school of nature, self-realization

\begin{abstract}
Abstrak
Makalah ini menjelaskan paradigma baru pendidikan Islam dalam perspektif humanisme dengan bertolak pada model sekolah alam. Model sekolah ini memiliki tiga aspek khusus, yakni: alam sebagai ruang belajar, alam sebagai media dan bahan mengajar, serta alam sebagai objek pembelajaran. Pendidikan seperti ini merupakan sebuah kreativitas dalam membangun paradigma pendidikan Islam yang humanis. Sistem pendidikan ini menekankan penyadaran untuk mendorong adanya proses dialog antara guru dan anak didik. Proses dialogis dapat memunculkan sikap rendah hati dan kasih sayang sehingga terbuka terhadap kritik dari peserta didik. Peserta didik dituntut kritis dan mempertanyakan kembali tentang hal yang belum diketahui oleh sang guru. Pembelajaran semacam ini memunculkan kesadaran siswa dan komunikasi yang harmonis antara semua pihak. Sekolah ini memberikan kebebasan untuk berkreasi, menggali dan menemukan potensi, serta menemukan pengetahuan berbasis pada pengalaman-pengalaman dari dunia realitas.
\end{abstract}

Kata kunci: pendidikan Islam, sekolah alam, penyadaran diri 


\section{A. Pendahuluan}

Pendidikan Islam sampai saat ini sepertinya belum memainkan peran strategisnya dalam menciptakan pribadi-pribadi muslim yang unggul dan berkepribadian baik. Hal ini disebabkan masih banyaknya praktek di lembaga-lembaga pendidikan Islam yang masih memberikan dominasi pada aspek kognitif dan penekanan pada aspek hafalan dalam memahami pendidikan keagamaan. Kepribadian dan akhlak anak didik hanya berhenti pada nilai angka-angka nominal semata, keberhasilan pendidikan agama diukur manakala anak memperoleh angka di atas KKM, kepintaran anak dinilai manakala mampu menghafal materi-materi agama yang sudah ditentukan berdasarkan bahan ajar yang ada dan batasan-batasan yang sudah dipersiapkan secara terukur dan terstruktur menurut aturan yang sangat sempit dan sangat minim terjadinya ruang dialog secara interaktif antar guru dan peserta didik. Anak hanya terjebak pada batasan salah dan benar, baik dan buruk, surga dan neraka, serta pahala dan siksa. Sehingga sangat sempit ruang bagi anak untuk bisa berpikir kreatif dan kritis, karena jawaban-jawaban anak didik ditentukan oleh benar dan salah yang ditentukan dalam buku-buku teks ajar semata.

Menurut Munir Mulkhan, sesungguhnya persoalan moral yang sedang dialami bangsa ini dimulai dari ruang kelas yang cacat moral dan memasung daya kritis dan kreativitas. Anak-anak hanya dipandang sebagai sosok yang hanya berharga jika sesuai citra guru, pengelola pendidikan, dan pemerintah. Anak-anak tidak pernah diajak untuk mengerti, mengalami, dan menyadari kebaikan dan kebenaran saat semuanya tersedia oleh paket-paket pembelajaran. Tuhan pun tak pernah dikenal dan disadari, kecuali sifat-sifat hebatNya yang harus dihafal tanpa bertanya. Penindasan kehendak adalah pengalaman paling jelas dan otentik sejak anakanak manusia memasuki bangku sekolah. ${ }^{1}$

Maraknya kehadiran sekolah alam saat ini seakan-akan memberikan angin segar dalam dunia pendidikan. Banyak kalangan yang menyambut hangat kehadiran sekolah yang berbasis alam sebagai bentuk kekecewaan dan keputusasaan atas harapan besar yang selama ini belum dipenuhi lembaga pendidikan konvensional. Sekolah alam dianggap menjadi

1 Abdul Munir Mulkhan, Nalar Spiritual Pendidikan, (Yogyakarta: Tiara Wacana, 2002), hlm. 74-75. 
alternatif baru dalam dunia pendidikan yang selama ini tengah mengalami kebosanan dan stagnasi keilmuan. Termasuk dalam dunia pendidikan Islam yang perlu pengalaman nyata, dan bentuk kesadaran diri melalui pengalaman keberagamaan yang nyata. Sekolah alam dekat dengan alam, sebagai bentuk tadabbur alam dan dekat dengan pengalaman nyata dalam kehidupan anak didik. Sehingga pendidikan Islam harus berubah ke arah pengalaman dan penyadaran diri tersebut. Berangkat dari persoalan tersebut di atas, maka makalah ini akan memfokuskan pada kajian pendidikan Islam berbasis sekolah alam sebagai bentuk perubahan ke arah paradigma baru pendidikan yang lebih humanis dan kreatif.

\section{B. Sekolah Alam: Model Perubahan Pendidikan Islam Humanis}

Pendidikan Islam sepertinya belum sepenuhnya mengakomodir kepentingan untuk menempatkan anak didik pada keunikan masing-masing. Hal ini ditunjukkan dengan masih adanya sentralisasi kebijakan dan strategi pendidikan yang menegasikan keunikan personal anak manusia. Sehingga yang terjadi dalam pendidikan Islam hanya sekedar mentransfer pengetahuan semata dan pada akhirnya menimbulkan terjadinya dehumanisasi dalam dunia pendidikan. ${ }^{2}$

Keberadaan Sekolah Alam yang saat ini mulai marak di lingkungan kita sepertinya menjadi alternatif baru dalam dunia pendidikan yang sedang mengalami kejenuhan dan stagnasi. Bagi kalangan yang kritis terhadap dunia pendidikan menyadari betapa pentingnya menghadirkan sekolah berwajah humanis yang selama ini belum terakomodir dalam sekolah formal pada umumnya. Maka, kehadiran sekolah alam ini dapat menjadi angin segar untuk menghidupkan kembali nilai-nilai kemanusiaan dalam dunia pendidikan.

\footnotetext{
${ }^{2}$ Dehumanisasi menjadi lawan kata humanisasi. Dalam kacamata Freire Humanisasi dan dehumanisasi adalah dua hal yang bersifat antagonistik. Dehumanisasi dalam pendidikan dimaksudkan sebagai proses pendidikan yang terbatas pada pemindahan ilmu pengetahuan (transfer of knowledge). Sedangkan humanisasi merupakan proses pemberdayaan masyarakat melalui ilmu pengetahuan. Lihat Paulo Freire, Politik Pendidikan: Kebudayaan, Kekuasaan dan Pembebasan, terj. Agung Prihantoro dan Fuad Arif Fudiyartanto, (Yogyakarta: Pustaka Pelajar \& READ, 2002), hlm. 190-191. Bandingkan pula dengan Said Tuhuleley (ed). Masa Depan Kemanusiaan, (Yogyakarta: Jendela, 2003), hlm. 7.
} 
Sekolah alam adalah bentuk pendidikan alternatif yang menggunakan alam sebagai media utama pembelajaran murid. Di sini, anak belajar dari semua makhluk yang ada di alam semesta. Dalam konsep pendidikan sekolah alam, terdapat 3 fungsi, yakni: alam sebagai ruang belajar, alam sebagai media dan bahan mengajar, alam sebagai objek pembelajaran.

Adapun ciri khas dari sekolah alam di antaranya; anak didik lebih banyak belajar di alam terbuka, metode belajar mengajar lebih banyak menggunakan metode action learning, yaitu anak didik belajar melalui pengalaman. Jika mengalaminya secara langsung, ia akan belajar lebih bersemangat, tidak bosan, dan lebih aktif, dan yang terpenting lagi penggunaan alam sebagai media belajar bertujuan agar murid lebih peduli dengan lingkungan dan bisa menerapkan pengetahuan yang dipelajari. ${ }^{3}$

Kehadiran sekolah alam ibarat sebuah impian yang menjadi kenyataan bagi mereka yang mengangankan dan menginginkan perubahan dalam dunia pendidikan. Bukan sekedar perubahan sistem, metode dan target pembelajaran, melainkan perubahan paradigma pendidikan secara menyeluruh yang pada akhirnya mengarah pada perbaikan mutu dan hasil dari proses pendidikan itu sendiri.

Di sekolah alam, anak didik dibebaskan bereksplorasi, bereksperimen dan berekspresi tanpa dibatasi sekat-sekat dinding yang mengekang rasa ingin tahu mereka yang membatasi interaksi mereka dengan kehidupan yang sebenarnya yang membuat mereka berjarak dan tidak akrab dengan alam lingkungan mereka.

Kehadiran sekolah alam ibarat sebuah impian yang menjadi kenyataan bagi mereka yang mengangankan dan menginginkan perubahan dalam dunia pendidikan. Bukan sekedar perubahan sistem, metode dan target pembelajaran, melainkan perubahan paradigma pendidikan secara menyeluruh yang pada akhirnya mengarah pada perbaikan mutu dan hasil dari proses pendidikan itu sendiri.

Di sekolah alam, anak didik dibebaskan bereksplorasi, bereksperimen dan berekspresi tanpa dibatasi sekat-sekat dinding yang mengekang rasa ingin tahu mereka yang membatasi interaksi

${ }^{3}$ www/Sekolah Alam/Keuntungan Anak Belajar di Sekolah Alam Usia Sekolah Parenting.co.id.htm. Diakses 7 Desember 2014. 
mereka dengan kehidupan yang sebenarnya yang membuat mereka berjarak dan tidak akrab dengan alam lingkungan mereka.

Anak didik dibebaskan menjadi diri mereka, dan mengembangkan potensi diri untuk tumbuh menjadi manusia yang berkarakter, berakhlak mulia, berwawasan ilmu pengetahuan dan siap menjadi pemimpin sesuai hakikat menciptakan manusia untuk menjadi pemimpin di muka bumi (khalifah fi al-ard). Anak didik juga dibebaskan dari tekanan 'mengejar' nilai dan ranking, tapi didorong untuk menumbuhkan tradisi ilmiah. Prestasi tidak dilihat dalam perbandingan dengan anak lain, tapi dari upaya mereka mengikuti proses belajar dengan baik. Belajar menjadi sesuatu yang menyenangkan. Bahkan belajar menjadi sebuah kebutuhan yang datang dari dalam diri anak didik dan bukan menjadi sebuah keterpaksaan. Dan yang terpenting lagi bagi anak didik adalah sekolah tidak menjadi penjara yang membosankan.

Sistem pendidikan di sekolah alam sesungguhnya lebih dapat mengakomodir keunikan masing-masing personal untuk dapat dikembangkan sesuai dengan minat dan potensinya. Sehingga bukan lagi penyeragaman yang diharapkan melainkan ketidakseragaman dan keunikan.

Karena sesungguhnya menurut Munir Mulkhan, pendidikan seharusnya menjadi wahana manusia untuk belajar menyelesaikan problem kehidupan yang sedang dan akan dihadapi. Namun sayangnya, pendidikan lebih sebagai sebuah paket peniruan gaya hidup versi penguasa, birokrat pendidikan dan para orang dewasa. Sehingga yang terjadi pendidikan sering terperangkap sebagai praktik kekunoan dan gaya hidup generasi terdahulu yang ketinggalan zaman. ${ }^{4}$

Humanisme dalam pendidikan menurut Darmiyati Zuchdi adalah bentuk pendidikan yang mempertimbangkan konsepsi moralitas. Konsepsi itu meliputi kepatuhan pada hukum moral, konformitas pada aturan-aturan sosial, otonomi rasional dalam hubungan antar pribadi, dan otonomi eksistensial dalam pilihan seseorang. Keempat konsepsi itu sebagai dasar pertimbangan capaian peserta didik dalam membentuk sifat-sifat human. ${ }^{5}$

\footnotetext{
${ }^{4}$ Abdul Munir Mulkhan, Nalar Spiritual..., hlm. 163-164.

5 Darmiyati Zuchdi, Humanisasi Pendidikan, (Jakarta: Bumi Aksara,
} 2008), hlm. 2. 
Dengan demikian, pendidikan Islam berbasis sekolah alam sesungguhnya mampu menjadi terobosan baru mencari format pendidikan Islam yang lebih humanis. Dengan pendidikan Islam berbasis sekolah alam diharapkan akan terjadi perubahan dalam semua dimensi pendidikan yang selama ini justru melanggengkan dehumanisasi.

\section{Mencari Arah Perubahan: Pendidikan Agama melalui Penyadaran Diri}

Pendidikan Agama sering terjebak pada persoalan hafalan semata, baik itu menghafal ayat-ayat al-Qur'an maupun teks-teks hadis nabi. Namun sesungguhnya yang terpenting dalam mengajarkan agama adalah bagaimana menjadikan nilai-nilai yang terkandung dalam ayat-ayat suci maupun hadis nabi tersebut memiliki kebermaknaan yang nyata dalam kehidupan anak didik. Sebagaimana menurut Kareel A. Steenbrink, bahwa memahami agama sesungguhnya tidak hanya meliputi hubungan antara manusia dengan Tuhan, melainkan juga antara manusia dengan manusia, dunia dan masyarakat, sejauh yang diatur dengan wahyu yang diturunkan Allah. ${ }^{6}$

Dari sini, maka sudah jelas sekali jika keberadaan pendidikan agama bukan berarti mengajarkan anak didik terkungkung oleh nilai-nilai normativitas keagamaan hanya untuk meningkatkan kesalehan personal semata, melainkan bagaimana pendidikan agama bisa membawa seorang anak didik pada kesalehan personal dan juga sosial.

Bila kita kembali berkiblat pada tujuan pendidikan nasional sebagaimana tercantum dalam UU Nomor 20 Tahun 2003 tentang Sistem Pendidikan Nasional adalah membentuk manusia yang berbudi pekerti luhur melalui proses pembentukan kepribadian, kemandirian dan norma-norma tentang baik dan buruk. Pendidikan diartikan sebagai suatu proses penyiapan generasi muda untuk menjalankan kehidupan dan memenuhi tujuan hidupnya secara lebih efektif dan efisien. Dan dalam pasal 1 UU Sistem Pendidikan Nasional juga jelas memposisikan bahwa pendidikan adalah usaha sadar dan terencana untuk mewujudkan suasana belajar dan proses pembelajaran agar peserta didik secara aktif mengembangkan

6 Kareel A. Steenbrink, Pesantren, Madrasah, Sekolah, (Jakarta: LP3ES, 1986), hlm. 107. 
potensi dirinya untuk memiliki kekuatan spiritual keagamaan, pengendalian diri, kepribadian, kecerdasan, akhlak serta keterampilan yang di perlukan dirinya, masyarakat, bangsa dan negara. $^{7}$

Dari penjelasan di atas sesungguhnya telah sangat jelas digambarkan bahwa pendidikan sebagai usaha sadar untuk mengaktualisasikan setiap potensi fitrah yang ada pada setiap manusia. Dan potensi tersebut harus dikembangkan untuk mengantarkan setiap individu pada proses pendewasaan sosial untuk mencapai perkembangan manusia seutuhnya. Dan di antara potensi fitrah manusia yang bisa dikembangkan adalah modal dasar manusia sebagai makhluk yang berpikir dan mempunyai kesadaran. Potensi tersebut dapat berkembang dengan baik manakala proses pendidikan yang diberikan menitikberatkan pada pada eksistensi manusia itu sendiri. Sementara proses pendidikan yang mendukung untuk terciptanya eksistensi manusia tentu mengarah kepada mekanisme yang demokratis dan senantiasa berorientasi pada proses memanusiakan manusia. Dengan begitu proses pendidikan bukan hanya semata-mata menjadi agen transfer ilmu pengetahuan, namun lebih mengarahkan dan membantu anak didik untuk bisa memaksimalkan potensinya dalam rangka menggali pengetahuan yang luas, kritis, dan komprehensif.

Paulo Freire seorang tokoh pendidikan Kritis asal Brazil yang memiliki pandangan yang lebih menekankan peserta didik sebagai subjek yang bebas ketimbang objek yang hanya menerima pengetahuan dari manusia yang dianggap lebih tahu kepada manusia yang dianggap belum tahu. Pendidikan kontekstual atau hadap masalah adalah sebuah teori dan model pendidikan yang mengupayakan peserta didik untuk menjadi subyek dalam rangka menjawab persoalan-persoalan yang muncul dalam realitas sosial. Freire menekankan peran berpikir dalam pembuatan kembali dunia. Dari sini fakta sosial bisa diungkapkan melalui pendidikan, dan menurut Freire, harus diupayakan adanya penyatuan (integration) dunia fakta (nyata) ke dalam dunia pendidikan. ${ }^{8}$

${ }^{7}$ Moh. Yamin, Menggugat Pendidikan Indonesia Belajar dari Paulo Freire dan Ki Hajar Dewantara, (Jogjakarta: Ar-Ruzz Media, 2009), hlm. 19.

8 Moh. Yamin, Menggugat Pendidikan ..., hlm. 19. Lihat pula http/elemen-elemen kritis dalam konsep pendidikan paulo freire.htm. Diakses 7 Desember 2014. 
Istilah penting yang diajukan Freire dalam Pedagogy of The Oppressed untuk mengajukan teorinya adalah penyadaran (conscientizacao) atau yang sering kita sebut "konsientisasi". Konsientisasi adalah pemahaman mengenai keadaan nyata yang sedang dialami siswa atau murid. Meskipun wilayah terakhir yang ingin dituju adalah perubahan sistemik, namun pendidikan Freire bertujuan untuk pembebasan dan pemanusiaan (humanisasi). Dalam rangka itulah Freire melihat bahwa 'penyadaran' (konsientisasi) sebagai inti dari pendidikannya. Pendidikan harus bertujuan menyadarkan peserta didik akan realitas sosialnya.

Freire (1979) membagi kesadaran manusia menjadi kesadaran magis, naif, dan kritis. Pertama, kesadaran magis (magical consciousness) adalah kesadaran masyarakat yang tidak mampu melihat kaitan antara satu faktor dengan faktor lain. Misalnya masyarakat miskin yang tidak mampu melihat kaitan antara kemiskinan mereka dengan sistem politik dan kebudayaan. Kesadaran ini lebih melihat pada faktor di luar manusia (natural maupun supranatural) sebagai penyebab dari ketidakberdayaannya.

Kedua, kesadaran naif (naival consciousness) yang lebih melihat aspek manusia menjadi akar permasalahan dalam masyarakat. Dalam kesadaran ini, masalah etika, kreativitas, need for achievement dianggap sebagai penentu perubahan sosial. Jadi dalam menganalisis mengapa suatu masyarakat miskin, mereka menganggap hal itu karena salah mereka sendiri.

Ketiga, kesadaran kritis (critical consciousness) yang lebih melihat pada aspek sistem dan struktur sebagai sumber masalah. Pendidikan mencoba menganalisis secara kritis sistem dan struktur sosial, politik, ekonomi, budaya, dan konteks masyarakat lainnya. Paradigma kritis dalam pendidikan adalah melatih siswa agar mampu mengidentifikasi ketidakadilan dalam sistem dan struktur yang ada, kemudian menganalisis bagaimana sistem itu bekerja, serta bagaimana mentransformasikannya. Tugas pendidikan dalam paradigma ini adalah menciptakan ruang dan kesempatan agar siswa terlibat aktif dalam proses penciptaan struktur yang secara fundamental baru dan lebih baik. ${ }^{9}$

${ }^{9}$ William A. Smith, Conscientizacou Tujuan Pendidikan Paulo Freire, terj. Agung Prihantoro, (Yogyakarta: Pustaka Pelajar, 2001). 
Hal positif yang dapat dipetik dari teori pendidikan kritis Freire mengenai penyadaran (konsientisasi) adalah bahwa pendidikan harus mendorong adanya proses dialogis antara guru (pengajar) dan anak didik. Maka dengan paradigma dialogis ini seorang pengajar harus rendah hati dan mengasihi peserta didiknya supaya terbuka terhadap berbagai kritik dari peserta didik. Sebaliknya, peserta didik seharusnya senantiasa kritis dan mempertanyakan kembali tentang hal yang belum diketahui oleh sang guru. Dari sini, akan terjadi komunikasi dua arah yang harmonis dan proses pembelajaran tidak hierarkis atas - bawah, pintar - bodoh, sudah tahu - belum tahu dan seterusnya.

Sementara Munir Mulkhan memformulasikan adanya integrasi kepribadian pada anak didik. Integrasi kepribadian ialah pribadi setiap individu yang terintegrasi pada setiap pertumbuhan dan perkembangan dirinya. Individu anak didik ini benar-benar menyadari bahwa hidupnya adalah sebuah "proses menjadi", "proses berubah" dan "proses berkembang". Di dalam proses situ seorang anak didik terus berusaha secara sadar memilih berbagai pengalaman yang kondusif atau mendukung perkembangan, perubahan dan pertumbuhannya tersebut. Karena pilihannya dan kesadarannya itulah anak didik dengan suka rela menerima risiko, menghadapi konflik dan pertentangan dengan keinginannya. ${ }^{10}$

Dalam proses pembelajaran agama sangat dibutuhkan nuansa dialogis-harmonis. Karena persoalan pembelajaran agama tidak semata bersifat indoktrinasi nilai-nilai yang dianggap sudah mapan dan tidak perlu dikritisi dan diinterpretasi kembali. Akan tetapi pembelajaran agama sesungguhnya sangat dinamis dan progresif, sehingga sangat terbuka akan adanya perkembanganperkembangan pengetahuan seiring dengan laju perkembangan zaman. Maka, pendidikan Islam perlu mengevaluasi kembali bagaimana proses pembelajaran agama yang selama ini diterapkan di sekolah-sekolah apakah sudah menuju pada humanisasi pendidikan ataukah masih terkungkung pada struktur kemapanan?

Di sekolah alam yang berbasis pada pendekatan pembebasan sangat dimungkinkan adanya ruang untuk mengarah pada pendidikan melalui penyadaran sebagaimana teori yang dikemukakan Freire tersebut. Karena dalam proses pembelajaran di sekolah alam anak didik sangat diberikan kebebasan untuk

${ }^{10}$ Abdul Munir Mulkhan, Nalar Spiritual..., hlm. 93. 
berkreasi, menggali dan menemukan potensi, serta menemukan pengetahuan berbasis pada pengalaman-pengalaman dari dunia realitas. Oleh karena itu, hal ini merupakan terobosan baru dalam dunia pendidikan yang patut diapresiasi dan alternatif lain dari pendidikan yang sudah mapan untuk menemukan eksistensi manusia seutuhnya.

\section{Peran Guru Sebagai Perantara Antara Manusia dan Tuhan}

Selama ini dalam mengajarkan agama guru cenderung menerapkan sikap hitam putih, baik - buruk, benar salah, surga neraka, serta pahala - dosa. Pola pengajaran agama yang selama ini diterapkan guru cenderung menutup ruang bagi anak didik untuk berpikir kritis, dan kreatif. Anak hanya disuguhi bahan-bahan yang siap jadi tanpa ada kompromi, dan harus ditelan secara mentah bahwa itulah ajaran agama yang tidak boleh ditentang adanya, apalagi diingkarinya. Yang terjadi anak didik membayangkan sesuatu yang menakutkan terlebih dahulu sebelum melaksanakan ajaran-ajaran tersebut. Bayangan dosa dan neraka telah menghantui dalam alam pikir dan perasaan anak didik. Dan yang terjadi adalah anak didik mendapatkan pengajaran agama bukan berdasarkan kesadaran dirinya melainkan karena ada unsur keterpaksaan untuk melaksanakan kewajiban semata.

Menurut Abdurrahman Mas'ud, konsep pendidikan Islam humanis seorang guru harus berperan sebagai orang yang mempersiapkan anak didik dengan kasih sayangnya sebagai individu yang saleh dalam arti memiliki tanggung jawab sosial, religius dan lingkungan hidup. Guru tidak hanya sekedar melakukan transfer of knowledge atau transfer of value saja tetapi lebih dari itu. Seorang guru harus bisa mengembangkan individu dalam rangka menerapkan dan meraih tanggung jawab. Ucapan, tata bersikap, dan tingkah laku seorang guru ditujukan agar siswa bisa menjadi insān kämil. ${ }^{11}$ Guru bukanlah orang yang serba dan paling mengerti dunia anak didiknya. Guru merupakan seseorang yang mampu mendorong siswa menyadari diri dan kemampuannya sendiri. ${ }^{12}$

${ }^{11}$ Abdurrahman Mas'ud, Menggagas Format Pendidikan Nondikotomik Humanisme Religius sebagai Paradigma Pendidikan Islam, (Yogyakarta: Gama Media, 2002), hlm. 196-197.

12 Abdul Munir Mulkhan, Nalar Spiritual..., hlm. 90. 
Untuk mewujudkan pendidikan Islam yang humanis harus dimulai dari guru yang humanis pula. Seorang guru yang humanis sangat menghindarkan adanya penekanan pada siswa. Seorang peserta didik diterima apa adanya, dengan kelebihan dan kekurangannya sehingga tidak ada yang merasa tertekan, baik pihak siswa maupun guru, psikis maupun fisiknya. Seorang guru humanis tidak pernah menginginkan anak didiknya hanya sekedar menjadi peniru dari model yang ditampilkan gurunya. Implikasi aliran humanisme dalam pendidikan adalah keniscayaan pengembangan potensi diri manusia sebagai anak didik. ${ }^{13}$

Di sekolah alam, guru harus mampu berkreasi dalam mengajar. Dan kreativitas guru tidak dibatasi oleh buku paket dan target nilai. Guru tidak hanya sekedar mengajar, tapi mendidik. Guru tidak hanya menjadi panutan, melainkan juga menjadi teman serta pendengar yang baik. Guru dalam hal ini lebih memainkan perannya sebagai seorang fasilitator ketimbang seorang tutor. Guru-guru memiliki idealisme tinggi dan berdedikasi di sekolah untuk membantu anak didik mengenali kelebihan dan kekurangannya serta menjadikan mereka merasa dihargai. Guru tidak sekedar kenal tapi paham; tidak sekedar berilmu tapi berkarakter dan berakhlak mulia; tidak sekedar mandiri tapi bisa membedakan mana yang baik dan yang tidak baik dikerjakan.

\section{E. Tadabbur Alam: Menggeser Pembelajaran Agama dari Paradigma Mitis ke Fungsional}

Proses pembelajaran di sekolah alam sudah seharusnya menjadikan alam sebagai sumber belajar, sarana, metode, bahkan strategi pembelajaran. Lingkungan anak yang dekat dengan alam sesungguhnya sangat strategis untuk mengajarkan agama berbasis lingkungan alam sekitar. Alam merupakan lingkungan yang paling dekat dan paling realistis bagi dunia anak. Sesungguhnya dalam proses pendidikan pun sangat diharapkan untuk mendekatkan anak didik pada alam nyata. Sehingga antara alam ide yang ada dalam teori-teori yang diajarkan di kelas sesungguhnya bisa berbanding lurus dengan apa yang ada di alam nyata. Sehingga benar apa yang dikatakan Paulo Freire bahwa tidak boleh ada dikotomi di antara

${ }^{13}$ Nur Chayati, "Menelusuri Akar Bungkamnya Daya Kritis", Edukasi, Vol. II, No.1, Januari, 2004, Fakultas Tarbiyah IAIN Walisongo Semarang, hlm. 60 . 
tujuan pendidikan dan cara pendidikan. Tujuan (transformasi yang membebaskan setiap orang agar menjadi manusia sejati), seharusnya terwujud dalam bagaimana pendidikan dilaksanakan. Tujuan pembebasan tidak tidak terpisahkan dari jalan yang membebaskan.

Pendidikan agama sesungguhnya sangat strategis jika anak didik didekatkan dengan dunia alam semesta. Karena sesungguhnya ajaran Islam yang dibawa oleh pesan-pesan alQur'an dan Hadis sarat dengan nilai-nilai yang memerintahkan manusia untuk berpikir menggunakan akal pikirnya untuk melakukan perenungan tentang alam semesta. Maka, sesungguhnya sangat ironi jika pembelajaran agama yang selama ini diajarkan di sekolah-sekolah hanya berhenti di antara temboktembok kelas yang membisu. Pembelajaran agama seyogianya tidak hanya menjadi menara gading yang seolah-olah tidak bisa disentuh oleh alam nyata, bahkan jauh dari dunia riil anak-anak. Karena sesungguhnya hal itu menyalahi kodrat kemanusiaan anak didik yang memang berada di alam nyata, tidak sedang mengembara dalam alam imaji yang sarat dengan teori-teori semata.

Alam bagi masyarakat primitif sebagaimana digambarkan Van Peursen memiliki daya magis yang dipenuhi dengan kekuatan-kekuatan gaib, diliputi rahasia dan sangat interesan. Jadi, inti sikap hidup mitis ialah bahwa kehidupan ini ada, ajaib dan berkuasa, penuh daya kekuatan. ${ }^{14}$

Sedangkan manusia modern memaknai alam tidak lagi hanya sebatas memiliki kekuatan magis dan bersifat gaib, tapi lebih kepada fungsi dan selalu menunjukkan kepada pengaruh terhadap sesuatu yang lain. Dan ini yang disebut oleh Van Peursen sebagai pemikiran fungsionalis. Apa yang disebut fungsional tidak berdiri sendiri, tetapi justru dalam suatu hubungan tertentu memperoleh arti dan maknanya. Dengan demikian, pemikiran fungsional menyangkut hubungan, pertautan, dan relasi. ${ }^{15}$

Dengan berpijak pada pemikiran Van Peursen tersebut, maka sesungguhnya saat ini untuk manusia modern sudah seharusnya terjadi pergeseran paradigma dari yang mitis menuju fungsionalis.

${ }^{14}$ Van Peursen, Strategi Kebudayaan, (Yogyakarta: Kanisius, 1988), hlm. 41-42.

${ }^{15}$ Peursen, Strategi Kebudayaan, hlm. 85. 
Alam tidak lagi menjadi sebuah fenomena yang menakutkan, penuh mistis dan gaib, sehingga dunia anak didik dijauhkan dari alam. Melainkan pendidikan Islam justru akan berubah jika mampu mendekatkan paradigma fungsionalis pada diri anak didik. Alam justru mempunyai fungsi yang sangat luar biasa terhadap dunia pembelajaran anak didik. Alam juga memberikan pengaruh yang luar biasa bagi pengembangan sains dan ilmu pengetahuan. Dengan demikian, pembelajaran agama berbasis sekolah alam sesungguhnya akan menghasilkan pengetahuan yang luar biasa jika mampu menjadikan paradigma fungsionalis sebagai paradigma pembelajaran yang mengarah kepada inovasi dan kreativitas belajar anak didik.

\section{F. Penutup}

Dalam konsep pendidikan sekolah alam, terdapat 3 fungsi, yakni: alam sebagai ruang belajar, alam sebagai media dan bahan mengajar, alam sebagai objek pembelajaran. Pendidikan Islam berbasis sekolah alam sesungguhnya mampu menjadi terobosan baru mencari format pendidikan Islam yang lebih humanis. Dengan pendidikan Islam berbasis sekolah alam diharapkan akan terjadi perubahan dalam semua dimensi pendidikan yang selama ini justru melanggengkan dehumanisasi. Dalam proses pembelajaran agama sangat dibutuhkan nuansa dialogis-harmonis. Karena persoalan pembelajaran agama tidak semata bersifat indoktrinasi nilai-nilai yang dianggap sudah mapan dan tidak perlu dikritisi dan direinterpretasi. Akan tetapi pembelajaran agama sesungguhnya sangat dinamis dan progresif.

Untuk mewujudkan pendidikan Islam yang humanis harus dimulai dari guru yang humanis pula. Seorang guru yang humanis sangat menghindarkan adanya penekanan pada siswa. Seorang peserta didik diterima apa adanya, dengan kelebihan dan kekurangannya sehingga tidak ada yang merasa tertekan, baik pihak siswa maupun guru, psikis maupun fisiknya. Seorang guru humanis tidak pernah menginginkan anak didiknya hanya sekedar menjadi peniru dari model yang ditampilkan gurunya. Implikasi aliran humanisme dalam pendidikan adalah keniscayaan pengembangan potensi diri manusia sebagai anak didik. Alam manusia modern sudah seharusnya terjadi pergeseran paradigma dari yang mitis menuju fungsional sehingga akan menjadikan 
proses pembelajaran agama berbasis sekolah alam akan menjadi lebih bermakna dalam kehidupan anak didik.

\section{Kepustakaan}

Freire, Paulo, Politik Pendidikan: Kebudayaan, Kekuasaan dan Pembebasan, terj. Agung Prihantoro dan Fuad Arif Fudiyartanto, (Yogyakarta: Pustaka Pelajar \& READ, 2002). http://sekolah alam/keuntungan anak belajar di sekolah alam usia sekolah parenting.co.id.htm, diunduh 7 Desember 2014.

http://elemen-elemen kritis dalam konsep pendidikan paulo freire.htm, diunduh 7 desember 2014.

Mas'ud, Abdurrahman, Menggagas Format Pendidikan

Nondikotomik Humanisme Religius sebagai Paradigma Pendidikan Islam, (Yogyakarta: Gama Media, 2002).

Mulkhan, Abdul Munir, Nalar Spiritual Pendidikan, (Yogyakarta: PT. Tiara Wacana, 2002).

Nur Chayati, "Menelusuri Akar Bungkamnya Daya Kritis", Edukasi, (vol. II, no. 1/Januari 2004).

Peursen, Van, Strategi Kebudayaan, (Yogyakarta: Kanisius, 1988).

Smith, William A., Conscientizacou Tujuan Pendidikan Paulo Freire, terj. Agung Prihantoro, (Yogyakarta: Pustaka Pelajar, 2001).

Steenbrink, Kareel A., Pesantren, Madrasah, Sekolah, (Jakarta: LP3ES, 1986).

Tuhuleley, Said, (ed), Masa Depan Kemanusiaan, (Yogyakarta: Jendela, 2003).

Yamin, Moh., Menggugat Pendidikan Indonesia Belajar dari Paulo Freire dan Ki Hajar Dewantara, (Yogjakarta: Ar-Ruzz Media, 2009).

Zuchdi, Darmiyati, Humanisasi Pendidikan, (Jakarta: Bumi Aksara, 2008). 


\title{
Desain Pengembangan Kurikulum Integratif
}

\author{
Husniyatus Salamah Zainiyati \\ UIN Sunan Ampel Surabaya
}

Email: husnayatus@yahoo.com

\begin{abstract}
Implementation of an integrated curriculum in UIN Maliki seeks to provide basic competencies of Islamic sciences as a characteristic of UIN, as well as the foundation for the development of fields of study are developed on existing majors. Study program ta'lim al-afkār al-Islämiyyah and ta'lim al-Qur'ān not only discuss the matter as Fiqh, Sufism, Aqeedah, but the study needs to be developed by taking the material Qur'an and Hadith relating to the development of science and technology. Basic Islamic knowledge can be used for students or faculty development studies field according to the respective department. The program not only as a prerequisite studies program at UIN Islamic subjects, but can be used to support other subjects. Ma'had tradition intended to form the character of students and develop Islamic culture on campus.
\end{abstract}

Keyword: integrative curriculum, ma'had 'âly

\begin{abstract}
Abstrak
Implementasi kurikulum integratif di UIN Maliki Malang berupaya memberikan kompetensi dasar ilmu-ilmu keislaman sebagai ciri khas UIN, sekaligus sebagai landasan bagi pengembangan bidang-bidang studi yang dikembangkan pada jurusan yang ada. Program kajian ta'lim al-afkār al-Islämiyyah dan ta'lim al-Qurān tidak hanya membahas materi seperti fiqh, tasawuf, aqidah, tetapi kajian perlu dikembangkan dengan mengambil materi Quran dan Hadis yang berhubungan dengan perkembangan sains dan teknologi. Dasar ilmu keislaman tersebut dapat digunakan mahasiswa atau dosen untuk pengembangan bidang kajian sesuai dengan jurusannya masing-masing. Program kajian tidak hanya sebagai prasyarat memprogram mata kuliah keislaman di UIN, akan tetapi bisa digunakan sebagai penunjang mata kuliah lainnya. Tradisi ma'had ditujukan untuk membentuk karakter mahasiswa dan mengembangkan kultur Islami di kampus.
\end{abstract}

Kata kunci: kurikulum integratif, ma 'had 'àly 


\section{A. Pendahuluan}

Perguruan tinggi dan pesantren sebenarnya memiliki akar budaya yang sama, yaitu sebagai lembaga pendidikan, hanya berbeda dalam lingkungannya. Jika perguruan tinggi dan pesantren dapat diintegrasikan dalam konteks yang integral, maka model atau sistem pendidikannya akan menjadi alternatif pengembangan pendidikan tinggi di Indonesia. Kemudian muncul pertanyaan, nilai-nilai apa saja yang dapat diambil dari pesantren, kemudian dibumikan dalam tradisi pendidikan di perguruan tinggi? Dalam hal ini, lembaga pesantren difungsikan untuk membangun tradisi yang kokoh. Tradisi yang dimaksudkan di sini adalah kebiasaan dan adat istiadat yang bernuansa Islami. Misalnya, kebiasaan melakukan salat berjamaah, tadarus al-Quran, salat malam, disiplin, menghormati sesama kolega, menghargai ilmu.

Kebutuhan untuk mengembangkan kurikulum integratif pada pendidikan tinggi Islam disebabkan oleh adanya tuntutan kebutuhan masyarakat dan perkembangan IPTEK. Sumardi menyatakan dalam suasana yang semakin kompetitif khususnya di bidang ilmu pengetahuan dan kemampuan intelektual lainnya, para sarjana IAIN adalah yang banyak menderita kekurangan. Pada umumnya pendekatan kurikuler di IAIN masih sangat doktriner dan dogmatis serta sarjana agama itu belum banyak "ber-try-out" dalam berbagai kesempatan.

Ma'arif mengungkapkan bahwa kaitan antara pendidikan Islam dan konsep Ilmu, setidak-tidaknya ada tiga persolan pokok yang saling berkaitan yang dapat dijabarkan menjadi; 1) sosok muslim yang menjadi gamang apabila dihadapkan kepada persoalan-persoalan dunia yang selalu berubah tampaknya disebabkan oleh idapan krisis identitas diri, sedangkan sistem pendidikan dan kurikulum pendidikan Islam yang sedang berlalu tidak dapat menolong keadaan; 2) kegiatan pendidikan Islam haruslah berorientasi ke arah transendental agar kegiatan itu punya makna spiritual yang mengatasi ruang dan waktu; 3) perlunya dilakukan redefinisi ulama. ${ }^{1}$

Untuk mengatasi berbagai kelemahan tersebut, maka Direktur Pendidikan Tinggi Islam (Diktis) mengambil kebijakan tentang pengembangan kurikulum PTAI, yaitu: 1) kurikulum berbasis hasil

${ }^{1}$ A Syafi'i Ma'arif, Peta Bumi Intelektualisme Islam di Indonesia, (Bandung: Mizan, 1993), hlm. 12. 
belajar; 2) kurikulum terdiri atas kurikulum inti dan kurikulum institusional; 3) kurikulum inti (40\%) ditetapkan oleh pemerintah dan berlaku secara nasional, sedangkan kurikulum institusional (60\%) ditetapkan oleh PTAI dan berlaku hanya di PTAI tersebut; 4) kurikulum secara keseluruhan (inti dan institusional) ditetapkan oleh PTAI; dan 5) kualitas kurikulum menjadi tanggung jawab PTAI. ${ }^{2}$

Kebijakan tersebut mengandung makna bahwa; 1) kurikulum perlu dikembangkan dengan lebih menitikberatkan pada pencapaian target kompetensi daripada penguasaan materi; 2) lebih mengakomodasikan keragaman kebutuhan dan sumber daya pendidikan yang tersedia; 3) memberikan kebebasan yang lebih luas kepada pelaksana pendidikan di PTAI untuk mengembangkan dan melaksanakan program pendidikan sesuai dengan kebutuhan; 4) menggunakan prinsip kesatuan dalam kebijakan dan keragaman dalam pelaksanaan. Hamalik menyatakan bahwa kebijakan yang bertujuan untuk meningkatkan angka partisipasi masyarakat dan mutu pendidikan menuntut adanya pengembangan kurikulum, sedangkan pengembangan kurikulum yang bertujuan untuk meningkatkan relevansi program pendidikan dapat dicapai melalui pengembangan kurikulum daerah dan sekolah/perguruan tinggi serta melibatkan ikut serta stakeholder. ${ }^{3}$

Berdasarkan studi pendahuluan diketahui bahwa UIN Maliki Malang merupakan salah satu PTAI yang menggunakan sistem penyelenggaraan pendidikan tinggi integratif yaitu sistem pendidikan dan tradisi di Ma'had Sunan Ampel al-Aly diintegrasikan ke dalam sistem pendidikan di UIN Maliki Malang. ${ }^{4}$ Menteri Agama RI-pada saat itu-Maftuh Basyuni juga mengacungi jempol terhadap UIN Malang. Ia mengatakan akan menerapkan program ke-ma'had-an seperti yang ada di UIN Malang pada seluruh Perguruan Tinggi Islam di Indonesia, sebagai pendukung pembelajaran mahasiswa yang berlatar belakang Islam. ${ }^{5}$ Implikasi dari sis-

${ }^{2}$ A. Furchan, dkk. Pengembangan Kurikulum Berbasis Kompetensi di PTAI, (Yogyakarta: Pustaka Pelajar, 2005), hlm. 33.

${ }^{3}$ Oemar Hamalik, Manajemen Pengembangan Kurikulum (Bandung: Rosdakarya, 2006), hlm. 4.

${ }^{4}$ Pedoman Pendidikan Universitas Islam Negeri (UIN) Malang Tahun Akademik 2006/2007, hlm. 144-145.

5 Tahap I pembangunan ma'had akan dilakukan pada 5 kota yaitu di UIN Jakarta, UINYogyakarta, IAIN Surabaya, Makasar dan Medan. Gema Media Informasi dan Kebijakan Kampus (edisi 25 November- Desember 2006), hlm. 7. 
tem pendidikan tinggi integratif tersebut, semua mahasiswa UIN Maliki Malang baik dari prodi umum maupun prodi agama pada tahun pertama diwajibkan bertempat tinggal di Ma'had UIN Maliki Malang dan mengikuti perkuliahan khusus program bahasa Arab (PKPBA) setiap hari pada pukul 14.00-20.00 WIB.

Tulisan ini akan membahas tentang bagaimana desain pengembangan kurikulum integratif pesantren mahasiswa dan UIN Maliki Malang. Penelitian ini menggunakan pendekatan deskriptif kualitatif. Pengumpulan data dihimpun dari observasi, wawancara dan dokumentasi. Data akan dianalisis melalui reduksi data, display data dan verifikasi atau kesimpulan.

\section{B. Desain Pengembangan Kurikulum Integratif Ma'had Sunan Ampel al-Aly dengan UIN Maliki Malang}

UIN Maliki Malang memanifestasikan konsep ūlul al-bāb dalam bentuk program pendidikan. A.M. Saefuddin menjelaskan bahwa ülul albāb adalah pemikir intelektual yang memiliki ketajaman analisis terhadap gejala dan proses alamiah dengan metode ilmiah induktif dan deduktif, serta intelektual yang membangun kepribadiannya dengan zikir dalam keadaan dan situasi apapun, sehingga mampu memanfaatkan gejala, proses, dan sarana alamiah ini untuk kemaslahatan dan kebahagiaan seluruh umat manusia. Ulul albāb adalah intelektual muslim yang tangguh, yang tidak hanya memiliki ketajaman analisis obyektif, tatapi juga subyektif. ${ }^{6}$ Tujuan pendidikan $\bar{u} l u l$ albāb, adalah menyiapkan peserta didik yang memiliki beberapa karakteristik tersebut.

Menurut UU Nomor 20/2003 tentang Sistem Pendidikan Nasional pasal 36 ayat (2), bahwa kurikulum pada semua jenjang dan jenis pendidikan dikembangkan dengan prinsip diversifikasi sesuai dengan satuan pendidikan, potensi daerah dan peserta didik. Dalam pasal 38 ayat (3) dijelaskan bahwa kurikulum pendidikan tinggi dikembangkan oleh perguruan tinggi yang bersangkutan dengan mengacu pada standar nasional pendidikan untuk setiap program studi.

Berdasarkan UU tersebut, menjadikan konsep ūlul albāb sebagai asumsi dasar dalam pengembangan pendidikan di UIN Maliki Malang merupakan perwujudan dari prinsip diversifikasi, sehingga dapat dibenarkan selama tetap memperhatikan standar nasional

\footnotetext{
${ }^{6}$ Saefuddin, Desekularisasi Pemikiran ..., hlm. 34.
} 
pendidikan. Untuk mewujudkan tujuan pendidikan tersebut, diperlukan struktur keilmuan yang jelas.

Gambar 1

Struktur Keilmuan Dikotomik

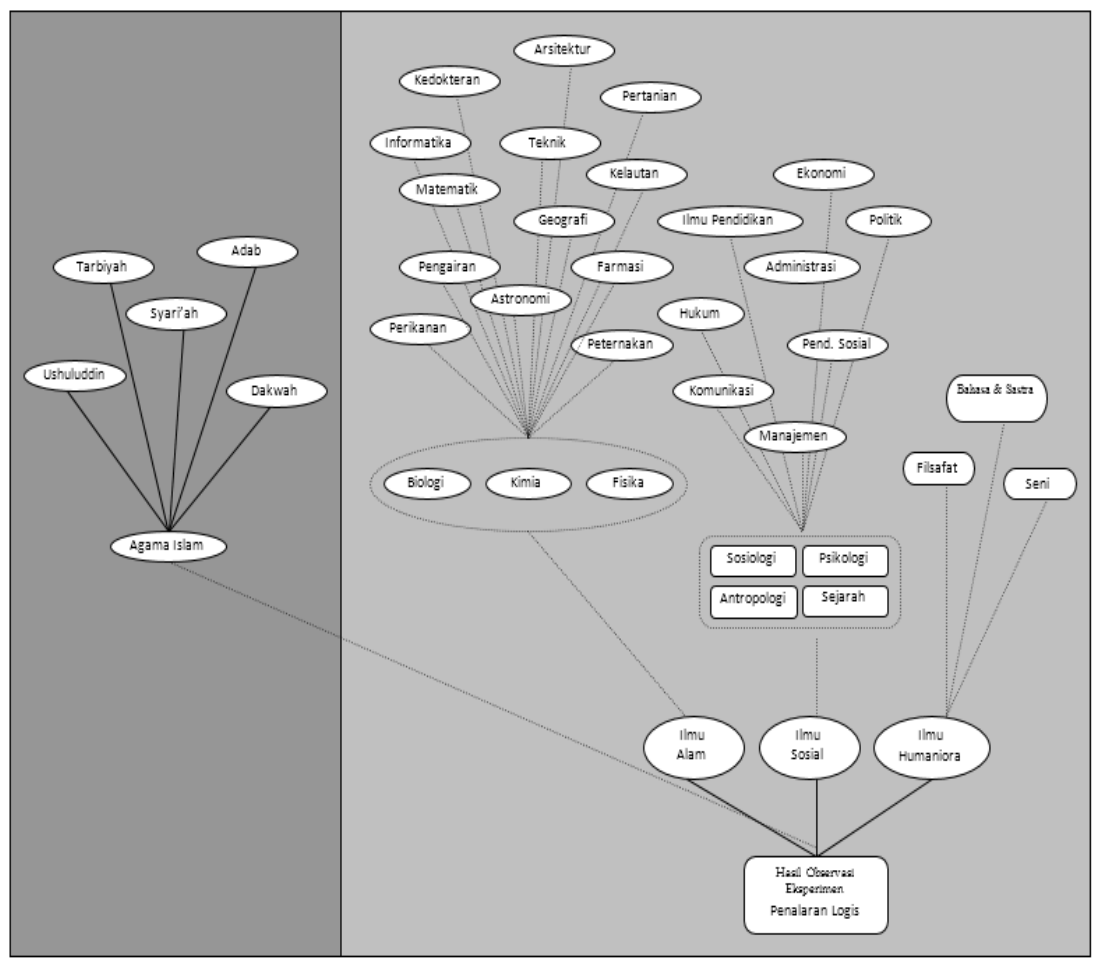

1. Struktur Keilmuan Integratif

Struktur keilmuan UIN Maliki Malang dibangun berdasarkan prinsip universalitas ajaran Islam yang digambarkan sebagai pohon ilmu yang rindang dan kokoh. Gagasan Imam Suprayogo tentang "Pohon Ilmu" yang dijadikan sebagai blue print pengembangan ilmu di UIN Maliki Malang, memang ada sedikit perdebatan pada tataran epistemologinya. Menurut Muhaimin, sumber ilmu pengetahuan itu pada dasarnya datangnya dari Allah. Allah menciptakan alam semesta (ayat kauniyyah) dan al-Quran serta al-Hadis (ayat qauliyyah). Oleh karenanya kedua sumber tersebut saling menjelaskan dan tidak bertentangan dengan berbagai ilmu pengetahuan tentang hakikat kebenaran. Selama ini orang berpikir di sayap kanan dan kiri disebut dikotomik. 
Berdasarkan temuan penelitian, menurut Imam Suprayogo ada dua tawaran terkait dengan peletakan al-Quran sebagai sumber ilmu pengetahuan. Pertama, meletakkan alQuran sebagai konsep dasar atau inspirasi yang kemudian dikembangkan melalui berbagai riset ilmiah (lihat gambar 1). Kedua, meletakkan al-Quran (fenomena naqliyah) dan alam (fenomena kauniyyah) menjadi dua sumber yang setara bagi bangunan ilmu pengetahuan (lihat gambar 2).

Gambar 2

Bangunan Keilmuan Integratif

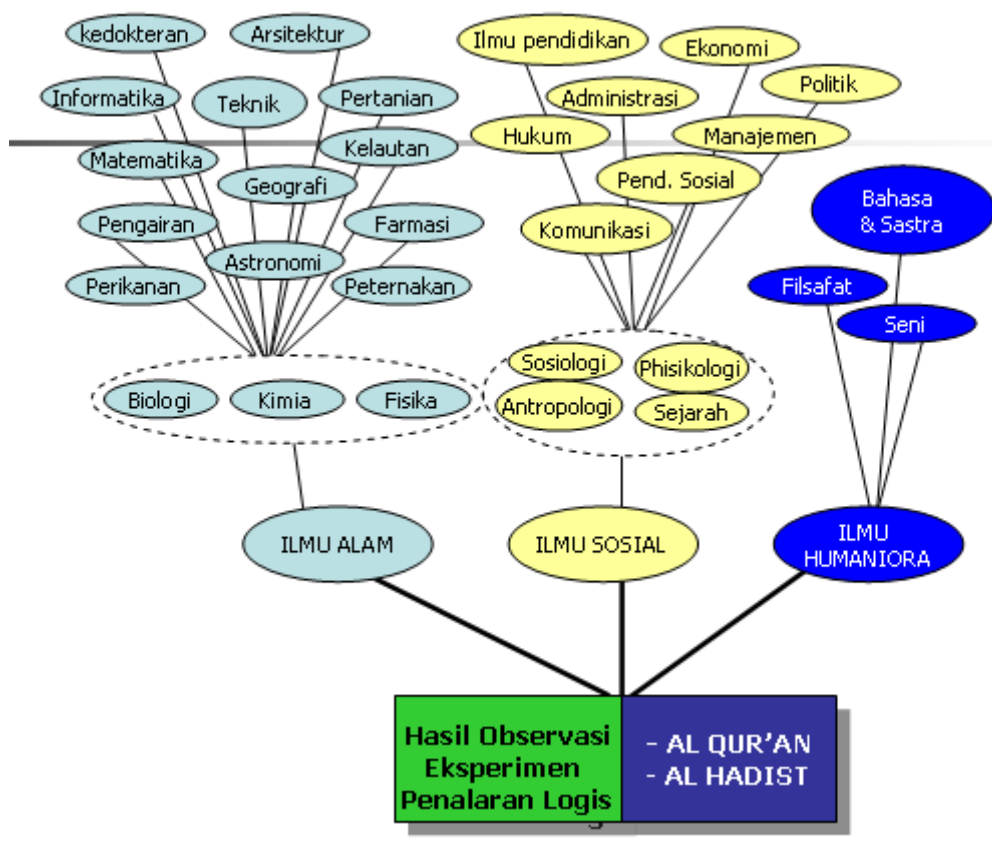

Pada gambar satu muncul sebuah pertanyaan, apa yang dimaksud dengan al-Quran sebagai sumber ilmu pengetahuan? Kalau yang dimaksud adalah al-Quran sebagai salah satu makhluk Tuhan yang dapat dijadikan sebagai salah satu sumber ilmu pengetahuan maka dapat dibenarkan, karena Allah juga menciptakan fenomena lain yang bersifat kauniyyah (alam semesta) dan fenomena nafsiyyah (manusia) yang juga memiliki kontribusi besar sebagai sumber ilmu pengetahuan, teknologi dan seni. 
Bagaimana bila al-Quran dijadikan sebagai sumber inspirasi, pertanyaan berikutnya adalah apakah seorang ilmuwan yang menggagas teori dari inspirasi yang melalui renungan tentang fenomena di sekitarnya tidak atau kurang Islami teorinya dari teori seorang ilmuwan yang mendapat inspirasi langsung dari al-Quran? Kalau dikatakan "ya", pertanyaan berikutnya adalah dengan ukuran apa sebuah teori dikatakan Islami dan tidak Islami? Apakah sebuah teori Islami semata-mata didasarkan atas sumber inspirasinya ataukah kejujuran ilmiah yang diemban oleh seorang ilmuwan sekalipun dia tidak memperoleh inspirasi dari al-Quran, atau bahkan mungkin dia tidak bisa membaca al-Quran? Kalau di dalam salah satu ayat al-Quran ditemukan istilah ḍarrah yang selama ini dijadikan pembenar atas teori atom, maka pertanyaannya adalah apakah itu bersifat justifikatif ataukah inspiratif, jika faktanya bahwa Niels Bohr menemukan atom tidak terinspirasi oleh ayat al-Quran. Jika faktanya hanyalah justifikatif, sering kali aplikasi praktis Islamization of knowledge adalah upaya mencari ayat atau hadis untuk menjustifikasi pengetahuan tertentu yang dianggap Islami, maka gugurlah klaim al-Quran sebagai sumber inspirasi ilmu pengetahuan. Kalau kemudian dikatakan bahwa ilmu pengetahuan dibangun dari proses riset ilmiah atas fakta empiris, lalu apa makna pernyataan al-Quran sebagai sumber ilmu pengetahuan tersebut? Oleh sebab itu, ada sekian banyak problem epistemologis yang terkait dengan dua hal tersebut. Cara pandang yang berbeda akan menghasilkan rumusan pengetahuan yang berbeda, baik mengenai alam maupun alQuran. ${ }^{7}$

Realitas keilmuan seperti ini semakin memperlihatkan bahwa aktivitas ilmiah adalah aktivitas ilmiah, dia tidak bisa disekat berdasarkan keyakinan-keyakinan religius apapun. Seorang ahli fisika secara keilmuan tidak harus bisa membaca al-Quran. Kalaupun bisa lebih baik sejauh rumusannya menggunakan prosedur keilmuan yang benar, bisa diterima, dan ini sama sekali tidak memiliki konsekuensi teologis Islam atau nonIslam. Sejauh ilmu-ilmu keislaman, seperti tafsir

${ }^{7}$ Zainul Hamdi, "Menilai Gagasan Ulang Islamisasi Ilmu sebagai Blue Print Pengembangan Keilmuan UIN", dalam Wahyudi, Integrasi Ilmu dan Agama ..., hlm. 186-188. 
dipahami sebagai satu ilmu, maka keharusan bagi seseorang untuk mengerti ilmu nahwu, ilmu saraf, ilmu mantiq, ilmu balagah, ilmu ma'ani ataupun bahasa Arab, dan berbagai perangkat rumpun ilmu-ilmu keislaman yang lain bukan sebagai keharusan teologis, tapi keharusan ilmiah, bahwa seseorang bisa mempelajari tafsir kalau dia memahami kaidah-kaidah bahasa Arab dan beberapa ilmu pendukungnya.

Jika kita menggagas suatu teori ilmiah yang dianggap berdasarkan al-Quran dan Hadis, maka itu hanyalah salah satu varian dari sekian banyak pandangan yang berbeda-beda. Sebuah ayat tidak bisa memberi priveles apapun terhadap teori kita atas teori lain yang tidak ada ayatnya. Bahkan menurut Hamdi ketika ada dua orang ilmuwan yang mendapatkan inspirasinya dari al-Quran, bisa jadi dia akan mengkonstruksi teori yang berbeda. Hal ini karena inspirasi Qur'ani lahir bukan sebagai sesuatu yang given, tapi disebabkan oleh cara seseorang memandang dan membaca alQuran. $^{8}$

Dalam hal ini, seperti diungkapkan Ahmad Tafsir bahwa ilmu adalah milik Allah, sehingga teori-teori yang didapat dari mempelajari al-Quran tidak mungkin berlawanan dengan teori-teori yang didapat dari mempelajari al-kaun (alam semesta) sebab dua kelompok teori itu adalah teori dari Tuhan, karena tidak ada perlawanan dalam pengetahuan Tuhan. ${ }^{9}$

Berdasarkan pemikiran tersebut, bahwa konsep integrasi ilmu umum dan ilmu agama yang digunakan sebagai blue print pengembangan keilmuan UIN Malang sebenarnya sebagai upaya untuk menghilangkan dikotomi keilmuan tersebut. ${ }^{10}$ Meskipun para ilmuwan dahulu seperti Ibn Khaldun membagi ilmu menjadi dua yaitu ilmu naqliyyah dan

\footnotetext{
${ }^{8}$ Hamdi, Integrasi Ilmu ..., hlm. 186-188.

${ }^{9}$ Ahmad Tafsir, Filsafat Pendidikan Islami Integrasi Jasmani, Rohani dan Kalbu Memanusiakan Manusia, (Bandung: Remaja Rosdakarya, 2010), hlm. 111.

${ }_{10}$ Mengenai konsep integrasi ilmu umum dan ilmu agama masingmasing UIN di Indonesia memiliki konsep keilmuan yang berbeda tetapi dengan tujuan yang sama. Misalnya UIN Syarif Hidayatullah Jakarta dengan konsep Integrasi Ilmu, UIN Sunan Kalijaga Yogyakarta dengan Jaring LabaLaba, UIN Bandung dengan konsep Wahyu Memandu Ilmu.
} 
ilmu 'aqliyah. Imam Gazali membuat klasifikasi ilmu menjadi ilmu-ilmu agama atau ukhrawi yang disebut fardu 'ain dan ilmu-ilmu umum atau duniawi disebut fardu kifayah. Kedua ilmu tersebut menurut al-Gaazali wajib ditempuh dan dimiliki oleh umat Islam. Menurut Azyumardi Azra klasifikasi ilmu tersebut bukan dimaksud mendikotomi ilmu antara satu dengan yang lain, tetapi hanya sekadar klasifikasi. Dalam konteks ini ilmu agama Islam merupakan salah satu saja dari berbagai cabang ilmu secara keseluruhan. ${ }^{11}$

Dengan demikian, Islamic knowledges (al-'ulüm al-Islämiyyah) yang dikembangkan oleh UIN Maliki Malang adalah ilmu pengetahuan yang dibangun berdasarkan ajaran Islam yakni al-Quran dan Hadis, sekaligus pengetahuan yang sama dibangun berdasarkan hasil observasi, eksperimentasi, dan penalaran logis. Jika al-Quran dan Hadis diletakkan pada posisi sumber ilmu, maka tidak akan terjadi cara pandang ilmu yang dikotomik dan justru merendahkan posisinya sebagai kitab suci. Sudah barang tentu sebagai konsekuensi al-Quran yang bersifat universal masih diperlukan sumber pengetahuan lain yang bersifat teknis, yaitu ilmu pengetahuan yang diperoleh melalui observasi, eksperimen dan penalaran logis.

Paparan di atas menegaskan bahwa konsep integrasi keilmuan UIN Malang, menegasikan Islam sebagai paradigma dalam berbagai kajian ilmu pengetahuan. Melalui pemahaman seperti ini ayat-ayat qauliyyah yang berhubungan dengan ilmu pengetahuan meniscayakan untuk dielaborasi secara saintifik sesuai dengan kebutuhan kerja ilmiah yang dibangunnya. Seperti diungkapkan Osman Bakar, al-Quran bukanlah kitab sains. Tetapi ia memberikan pengetahuan tentang prinsip-prinsip sains, yang selalu dikaitkannya dengan pengetahuan metafisik dan spiritual. ${ }^{12}$ Gagasan tersebut sesuai dengan pendapat Endang Saefuddin Ansari bahwa al-Quran atau ayat Qur'aniyyah tidak lain adalah pembukuan segenap alam semesta atau ayat kauniyyah dalam satu al-Kitab. Kedua ayat Allah yaitu ayat Qurāniyah dan ayat kauniyyah itu

\footnotetext{
${ }^{11}$ Azra, Pendidikan Islam ..., hlm. xii-xiv.

${ }^{12}$ Bakar, Tauhid dan Sains ..., hlm. 151.
} 
saling menafsirkan. ${ }^{13}$ Dalam proses pengilmuan Islam Kuntowijoyo menawarkan dua metodologi, yaitu integralisasi dan objektivikasi. ${ }^{14}$

2. Kurikulum integratif yang dikembangkan

Untuk merealisasikan struktur keilmuan dengan metafora pohon ilmu, kurikulum UIN Maliki Malang diintegrasikan dengan program Ma'had Sunan Ampel al-Aly. Berdasarkan struktur keilmuan tersebut, UIN Maliki Malang mewajibkan seluruh mahasiswa tanpa melihat jurusan atau program studi apa, untuk menguasai pondasi atau akar keilmuan lebih dahulu terdiri dari; 1) Bahasa Arab dan Bahasa Inggris, 2) Filsafat, 3) Ilmu Kealaman, 4) Ilmu Sosial, dan 5) Pendidikan Pancasila dan Kewarganegaraan, sebelum mengkaji ajaran Islam (pada pohon ilmu digambarkan sebagai sebuah batang), meliputi; 1) al-Quran dan al-Sunnah, 2) Sirah Nabawiyah dan Sejarah Peradaban Islam, 3) Pemikiran Islam terdiri atas; Teologi, Fiqih, dan Tasawuf, 4) Pemahaman terhadap masyarakat Islam. Selanjutnya mahasiswa mengkaji keilmuan sesuai dengan pilihan dan jurusan serta program studi masingmasing (yang digambarkan sebagai sebuah dahan dan ranting).

Struktur kurikulum tersebut bila dikaitkan dengan realitas sejarah pengembangan perguruan tinggi Islam didorong oleh beberapa tujuan, yaitu; 1) untuk melaksanakan pengkajian dan pengembangan ilmu-ilmu agama Islam pada tingkat yang lebih tinggi secara lebih sistematis dan terarah; 2) untuk melaksanakan pengembangan dan peningkatan dakwah Islam; dan 3) untuk melakukan reproduksi dan kaderisasi ulama dan fungsionaris keagamaan, baik pada birokrasi negara maupun sektor swasta, serta lembaga-lembaga sosial, dakwah, pendidikan dan sebagainya. ${ }^{15}$ Maka pemahaman akan tujuan yang pertama berimplikasi pada tujuan kedua dan ketiga tersebut di atas.

Tujuan kedua adalah untuk melaksanakan pengembangan dan peningkatan dakwah Islam. Makna dakwah Islam bukan

13 Endang Saifuddin Anshari, Ilmu, Filsafat dan Agama, (Surabaya: Bina Ilmu, 1987), hlm. 176.

${ }^{14}$ Kuntowijoyo, Islam sebagai Ilmu ...., hlm. 49.

${ }^{15}$ Azra, Pendidikan Islam ..., hlm. 170. 
lagi tereduksi menjadi dakwah dalam arti mengomunikasikan al-'ulüm al-naqliyah (perennial knowledge) saja, yang mencakup: studi al-qur'an, studi hadis, sirah nabawiyyah, tauḥid, ușūl fiqh dan fiqh, bahasa Arab, serta bidang-bidang studi tambahan yang meliputi; Metafisika Islam, Perbandingan Agama, dan Sejarah Kebudayaan Islam. Tetapi menurut Bilgrami juga bagaimana al-'ulüm al-naqliyyah (perennial knowledge) memberi spirit dan landasan, serta ancangan bagi pengembangan al-'ulum al-aqliyyah (acquired knowledge), yang mencakup: 1) Arts (ilmu-ilmu imajinatif), seperti, kesenian dan arsitektur Islam, bahasa-bahasa, kesusasteraan; 2) ilmu-ilmu intelektual, yang meliputi: ilmuilmu sosial, filsafat, pendidikan, ekonomi, ilmu politik, sejarah, peradaban Islam, geografi, sosiologi, linguistik, psikologi, antropologi; 3) ilmu-ilmu kealaman, yang meliputi: filsafat ilmu pengetahuan, matematika, statistika, fisika, kimia, biologi, astronomi, ilmu-ilmu angkasa luar dan sebagainya; 4) ilmu-ilmu terapan, yang meliputi teknik dan teknologi, kedokteran, pertanian dan kehutanan; 5) ilmu-ilmu praktis, meliputi: perdagangan, ilmu-ilmu administrasi, ilmuilmu perpustakaan, ilmu-ilmu kerumahtanggaan, ilmu komunikasi dan sebagainya. ${ }^{16}$

Sedangkan tujuan ketiga adalah untuk melakukan reproduksi dan kaderisasi ulama. Pemahaman tentang ulama bukan lagi terbatas pada mereka yang menguasai al-'ulüm alnaqliyyah (perennial knowledge), tetapi juga mereka yang menguasai al-'ulum al-aqliyah (acquired knowledge), serta menjadikan al-'ulüm al-naqliyyah (perennial knowledge) sebagai landasan, spirit serta ancangan bagi pengembangan al-'ulüm al-aqliyyah (acquired knowledge) tersebut.

Dilihat dari sudut pandang tersebut, menurut Muhaimin, ${ }^{17}$ studi keislaman akan mengalami pemekaran makna, yaitu: pertama, studi Islam sebagai sumber ajaran yang merupakan wahyu Ilahi yang terhimpun dalam al-Quran dan Hadis. Dalam bidang yang pertama ini, studi Islam bertumpu pada studi kewahyuan yang diwujudkan dalam bentuk mata kuliah seperti studi al-Quran, studi hadis dan lain-lainnya.

\footnotetext{
${ }^{16}$ Bilgrami dan Ashraf, Konsep Universitas Islam ..., hlm. 14-20.

${ }^{17}$ Zainuddin, dkk. (ed), Memadu Sains dan Agama ..., hlm. xxvii-xxviii.
} 
Kedua, studi Islam sebagai bagian dari pemikiran atau bagian dari fiqh dalam arti luas. Dalam sejarah pemikiran Islam setidak-tidaknya ada lima bidang pemikiran Islam yang menonjol, yaitu: akidah-teologi (ilmu kalam), hukum dalam arti luas (syari' 'ah), filsafat, akhlak-sufisme (tasawuf), ilmu pengetahuan teknologi seni (al-'ulüm al-dunyawiyah), yang mencakup bidang-bidang yang mencakup luas mulai dari IPA, matematika hingga teknik arsitektur, informatika dan astronomi. Ketiga, studi Islam sebagaimana yang dialami, diamalkan dan diterapkan dalam kehidupan. Dengan bersumber pada al-Quran dan Hadis, kemudian dijabarkan dalam berbagai pemikiran, ajaran Islam lalu diamalkan dan diterapkan oleh umat Islam hingga membentuk peradaban Islam.

Kajian yang dikembangkan UIN Maliki Malang untuk penyiapan ulül albāb tidak sekedar menekankan pada pengembangan ilmu-ilmu pengetahuan agama Islam dalam arti al-'ulüm al-naqliyah (bersumber wahyu), tetapi sekaligus menyangkut kajian al- 'ulüm al-aqliyah (bersumber pada alam semesta) yang bersifat empiris, selaras dengan karakteristik $u l \bar{l} l$ albāb tersebut di atas. Karena itulah, pengembangan al'ulüm al-naqliyah semata dianggap kurang relevan lagi dengan pengembangan ilmu pengetahuan dan tuntutan pembangunan nasional, karena bersifat sangat sektoral, hanya memenuhi satu sektor tertentu dalam kehidupan Islam di Indonesia, yaitu memenuhi kebutuhan sarjana-sarjana yang mendapatkan pengetahuan tinggi mengenai agama Islam. Dengan demikian konsep ulūl albāb yang diharapkan adalah mereka yang menguasai iptek dan sekaligus hidup di dalam nilai-nilai agama Islam.

Berdasarkan buku Pedoman Pendidikan Fakultas Tarbiyah UIN Maliki Malang tahun 2012, Mata Kuliah Dasar Keuniversitasan yang harus ditempuh oleh semua mahasiswa UIN Maliki Malang, terdiri dari: a) Pendidikan Kewarganegaraan, b) Bahasa Indonesia, c) Bahasa Inggris, d) Ilmu Alamiah Dasar, e) Ilmu Budaya Dasar, f) Filsafat Ilmu, g) Studi al-Qur'an, h) Studi al-Hadis, i) Studi Fiqh, j) Akhlak/Tasawuf, k) Sejarah Peradaban Islam, 1) Teologi Islam, m) Maharat al-Istima’ I, II, n) Maharat al-Kalām I, II, 
o) Maharat al-Qiraah I, II, p )Maharat al-Kitabah I, II, q) Tarbiyah Ulül Albāb. ${ }^{18}$

Untuk tercapainya pengembangan pada mata kuliah dasar di universitas tersebut, maka menurut Muhaimin harus dibarengi dengan pembiasaan dan pembelajaran di ma'had. Oleh karena itulah, struktur kurikulum mata kuliah dasar keuniversitasan UIN Malang diintegrasikan dengan pembelajaran di Ma'had Sunan Ampel al-Aly, dengan menjadikan sertifikat kelulusan ta'lim al-afkar al-Islämi dan ta'lim al-Qurān sebagai prasarat untuk memprogram studi keislaman, dan sebagai prasarat ujian komprehensif. Bagi mahasiswa yang belum lulus, maka mahasiswa tersebut dapat memprogram mata kuliah studi keIslaman dengan syarat tetap mengikuti program remidial ta'tim ma'had sampai yang bersangkutan dinyatakan lulus, dan nilai kelulusan program remidial tersebut menjadi syarat penerbitan nilai akhir untuk mata kuliah studi keislaman yang diprogram. ${ }^{19}$

Program sabāh al-lugah yang dilaksanakan di ma'had, PKPBA dan PKPBI dilaksanakan di UIN Maliki Malang untuk memperkuat kemampuan bahasa Arab dan Inggris mahasiswa, yang pada gilirannya dapat digunakan sebagai alat untuk mengkaji sumber ajaran Islam dan juga disiplin ilmu masing-masing. Seperti diungkapkan Karel A. Steenbrink bahwa penguasaan bahasa Arab juga penting di luar penguasaan Agama. ${ }^{20}$ Sedangkan pembinaan kajian al-Quran bagi dosen melalui kegiatan di LKQS, pembinaan membaca al-Quran bagi karyawan melalui kegiatan tahsīn al-Qurān di HTQ.

Pembelajaran di Ma'had Sunan Ampel al-Aly adalah bagian integral dari sistem kelembagaan dan pendidikan UIN Maliki Malang. Karena itulah, pembelajaran di ma'had diatur oleh Pembantu Rektor Bidang Akademik melalui mudir dan pengurus ma'had, baik menyangkut kurikulum, perkuliahan, dan sistem evaluasi. Hal ini untuk mengukur tingkat keberhasilan pembelajaran ta'Tim al-afkār al-Islämi dan ta'Tim al-Qurān.

${ }^{18}$ Pedoman Pendidikan Fakultas Tarbiyah UIN Maliki Malang, 2010, hlm. 35-36.

${ }^{19}$ Pedoman Pendidikan UIN Maliki Malang, 2010, hlm. 53.

${ }^{20}$ Steenbrink, Pesantren Madrasah ..., hlm. 176. 
Sebagaimana diungkapkan oleh Hasyim bahwa pesantren dapat dijadikan sebagai sistem pendidikan alternatif yaitu, pertama, apabila pesantren tidak menolak perkembangan paradigma sains dan teknologi modern, dengan tanpa meninggalkan nilai-nilai paradigma keislaman. Kedua, harus ada sebuah kurikulum yang seimbang antara trilogi keilmuan yang berlandaskan Islam; 1) Islamic natural sciences; 2) Islamic social science; 3) religion sciences. Diharapkan dengan kurikulum ini, santri dapat menggabungkan antara pengetahuan, keterampilan dan sikap. ${ }^{21}$

\section{Gambar 3}

Integrasi Kurikulum UIN dengan Ma'had Sunan Ampel al-Aly

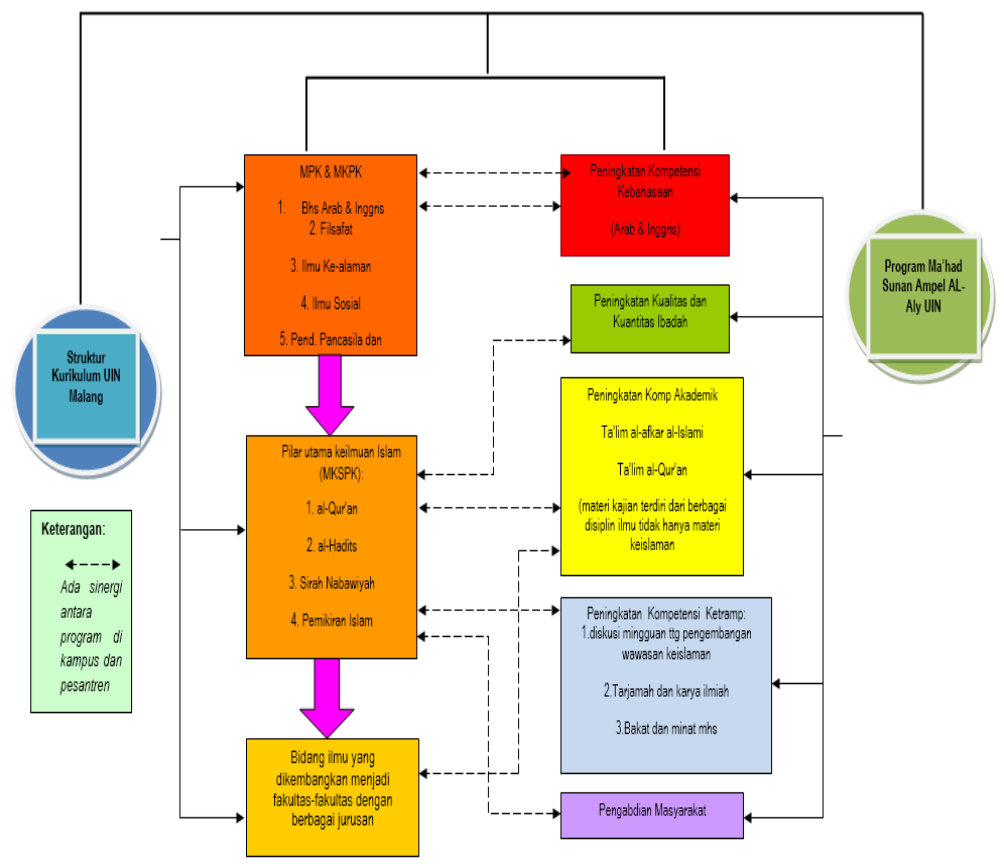

Implementasi kurikulum integratif di UIN Maliki Malang menurut peneliti, menggunakan pendekatan kebutuhan sosial (social demand approach) yang diajukan Gorton. Dengan alasan dalam rangka mewujudkan visi dan misi UIN Maliki

${ }^{21}$ M. Affan Hasyim, "Menatap Masa Depan Pesantren dalam Menyongsong Indonesia Baru”, dalam Menggagas Pesantren ..., hlm. 231. 
Malang dengan empat pilar yaitu; 1) Kedalaman Spiritual; 2) Keluhuran Akhlak; 3) Keluasan Ilmu Pengetahuan; dan 4) Kematangan Profesional, maka model pembelajaran di UIN Maliki Malang adalah dengan mengintegrasikan kurikulum ma'had dengan kurikulum UIN. Di samping itu, Muhaimin juga menambahkan bahwa, pengembangan kurikulum di UIN Malang menggunakan empat pendekatan dengan mempertimbangkan karakteristik tujuan dan isi kurikulumnya, yaitu; 1) pendekatan subyek akademik; 2) pendekatan humanistik; 3) pendekatan teknologik; 4) pendekatan rekonstruksi sosial. Skema kurikulum integratif Ma'had 'Āly dan UIN Maliki Malang dapat dilihat pada gambar 3.

\section{Penutup}

Berdasarkan paparan data di atas dapat disimpulkan bahwa struktur keilmuan UIN Maliki Malang dengan metafora pohon ilmu bersifat dialogis-konsultatif. Kurikulum UIN Maliki Malang mengintegrasikan program Ma'had Sunan Ampel Al-Aly dengan kurikulum UIN Maliki Malang, dengan menjadikan sertifikat kelulusan ta'Tim al-afkār al-Islämì dan ta'Tim al-Qurān sebagai prasarat untuk memprogram studi keislaman dan sebagai prasarat ujian komprehensif. Pembinaan kajian al-Quran bagi dosen melalui kegiatan di LKQS dan pembinaan membaca al-Quran bagi karyawan melalui kegiatan tahsin al-Qurān dan pembinaan hafalan al-Quran mahasiswa di HTQ.

Langkah-langkah yang dapat digunakan untuk menerapkan pembelajaran berparadigma Qur'ani yaitu; a) memetakan konsep keilmuan umum dan keilmuan agama; b) memadukan konsep keilmuan umum dan keilmuan agama; c) mengelaborasi ayat-ayat al-Quran yang relevan secara saintifik. Tradisi ma'had seperti salat berjama'ah, zikir bersama, khatm al-qur'ān dan hifz al-qur'ān, puasa senin dan kamis, infaq dan shadaqah untuk membentuk karakter mahasiswa dan mengembangkan kultur Islami di kalangan civitas akademika UIN Maliki Malang. Tradisi pesantren juga dikembangkan sebagai wahana pendidikan kepemimpinan umat dan pengembangan kecakapan berbahasa Arab dan Inggris. Dengan demikian, model pengorganisasian kurikulum UIN Maliki Malang menggunakan correlated curriculum.

\section{Kepustakaan}


Abdullah, Amin, "Imam Suprayogo dan Ki Hajar Dewantara: Pelopor Pendidikan yang Teguh Pendirian dan Visioner", dalam Ahmad Barizi (ed.), Membangun Pendidikan dalam Bingkai Islam Lintas Batas, (Malang: UIN Malang Press, 2011).

A'la, Abd., Pembaruan Pesantren,(Yogyakarta: LKiS, 2006).

Al-Attas, Syed Muhammad Naquib, Islam dan Sekularisme, (Bandung: Pustaka, 1981).

Al-Faruqi, Ismail Raji, Islamisasi Pengetahuan, terj. Anas Mahyuddin, (Bandung: Pustaka, 1984).

Ahmad Tafsir, Filsafat Pendidikan Islam Integrasi Jasmani, Rohani, dan Kalbu Memanusiakan Manusia, (Bandung: Remaja Rosdakarya, 2010).

Anwar, Miski, "Tradisi Pesantren di Tengah Transformasi Sosial", dalam A.Z. Fanani dkk. (peny.), Menggagas Pesantren Masa Depan Geliat Suara Santri Untuk Indonesia Baru, (Yogyakarta: Qirtas, 2003).

Asrohah, Hanun, Kelembagaan Pesantren Asal-usul dan Perkembangan Pesantren di Jawa, (Jakarta: Bagian Proyek Peningkatan Informasi Penelitian dan Diklat Keagamaan, 2004).

Azizy, A. Qodri Abdillah, "Pengantar: Memberdayakan Pesantren dan Madrasah", dalam Ismail SM, Nurul Huda dan Abdul Khaliq (ed.). Dinamika Pesantren dan Madrasah, (Yogyakarta: Pustaka Pelajar, 2002).

Azra, Azyumardi, Pendidikan Islam Tradisi dan Modernisasi Menuju Milenium Baru, (Jakarta: Logos Wacana Ilmu, 1999).

Bagir, Zainal Abidin, "Bagaimana Mengintegrasikan Ilmu dan Agama?", dalam Jarot Wahyudi, dkk. (editor), Integrasi Ilmu dan Agama: Interpretasi dan Aksi, (Yogyakarta: MYIACRCS dan Suka Press, 2005).

Barbour, Ian G., Juru Bicara Tuhan antara Sains dan Agama, terj. E.R. Muhammad, (Bandung: Mizan, 2002).

Barizi, Ahmad (ed.), Holistik Pemikiran Pendidikan A. Malik Fadjar, (Jakarta: Raja Grafindo Persada, 2005). 
Bilgrami, Hamid Hasan dan Sayid Ali Ashraf, Konsep Universitas Islam, terj. Machnun Husein, (Yogyakarta: Tiara Wacana, 1999).

Dhofier, Zamakhsyari, Tradisi Pesantren, Sudi Tentang Pandangan Hidup Kyai, (Jakarta: LP3ES, 1982).

Djubaedi, Dedi, "Pemaduan Pendidikan Pesantren-Sekolah: Telaah Teoritis dalam Perspektif Pendidikan Nasional" dalam Marzuki Wahid dkk (ed.). Pesantren Masa Depan Wacana Pemberdayaan dan Transformasi Pesantren. (Bandung: Pustaka Hidayah, 1999).

Gorton, School Administration Challenge and Opportunity for Leadership, (New York: Brown Company, 1976).

Haedari, M. Amin dan Abdullah Hanif (ed.), Masa Depan Pesantren dalam Tantangan Modernitas dan Tantangan Kompleksitas Global, (Jakarta: IRD Press, 2004).

Hamdi, Zainul, "Menilai Ulang Gagasan Integrasi Ilmu Pengetahuan sebagai Blue Print Pengembangan Keilmuan UIN", dalam Zainal Abidin Bagir, dkk (editor), Integrasi Ilmu dan Agama Interpretasi dan Aksi (Yogyakarta: MYIA-CRCS dan Suka Press, 2005).

Hamim, Thoha, Islam dan NU: Di Bawah Tekanan Problematika Kontemporer: Dialektika Kehidupan Politik, Agama, Pendidikan dan Sosial Masyarakat Muslim. (Surabaya: Diantama, 2004).

Hidayat, Komarudin, "Menimbang Kurikulum 1997" dalam Perta, (vol. I no. 9/1997), hlm. 12-17.

Hirokoshi, Hiroko, Kyai dan Perubahan Sosial, terj. Umar Basalim dan Andi Muarly Sunrawa, (Jakarta: LP3ES, 1987).

Kuntowijoyo, Paradigma Islam Interpretasi untuk Aksi, (Bandung: Mizan, 1991).

Kuswanjono, Arqom, Integrasi Ilmu dan agama Perspektif Filsafat Mulla Sadra, (Yogyakarta: Lima, 2010).

Ma'arif, Syafi'i, Peta Bumi Intelektualisme Islam di Indonesia, (Bandung: Mizan, 1993).

Mahzar, Armahedi, "Integrasi Sains dan Agama: Model dan Metodologi”, dalam Jarot Wahyudi, Integrasi Ilmu dan Agama: Interpretasi dan Aksi, (Yogyakarta: MYIA-CRCS dan Suka Press, 2005). 
Mastuhu, Memberdayakan Sistem Pendidikan Islam, (Jakarta: Logos, 1999).

------, Dinamika Sistem Pendidikan Pesantren, (Jakarta: INIS, 1994).

Muhaimin, Arah Pengembangan Pendidikan Islam Pemberdayaan, Pengembangan Kurikulum Hingga Redifinisi Islamisasi Pengetahuan, (Bandung: Nuansa, 2003).

------, Wacana Pengembangan Pendidikan Islam, (Yogyakarta: Pustaka Pelajar, 2003).

Pedoman Pendidikan Universitas Islam Negeri (UIN) Malang Tahun Akademik 2011/2012.

Qomar, Mujamil, Pesantren Dari Transformasi Metodologi Menuju Demokratisasi Institusi, (Jakarta: Erlangga, t.t.).

Rahardjo, Dawam (ed.), Pesantren dan Pembaharuan, (Jakarta: LP3ES, 1974).

Saefuddin, A.M., et.al., Desekularisasi Pemikiran: Landasan Islamisasi, (Bandung: Mizan, 1998).

Suprayogo, Imam, "Relasi Kajian Islam dan Sains dalam Merespon Tantangan Lokal dan Global", Annual Conference Kajian Islam (Bandung, 26-30 November 2006).

------, Universitas Islam Unggul Refleksi Pemikiran Pengembangan Kelembagaan dan Reformulasi Paradigma Keilmuan Islam, (Malang: UIN Malang Press, 2009).

------, Hubungan antara Perguruan Tinggi dan Pesantren, (Malang: UIN Malang Press, 2007).

Tholkhah, Imam, dkk., Membuka Jendela Pendidikan Mengurai Akar Tradisi dan Intregasi Keilmuan Pendidikan Islam, (Jakarta: Raja Grasindo Persada, 2004).

Wahid, Marzuki, "Ma'had Aly: Nestapa Tradisionalisme dan Tradisi Akademik yang Hilang", Jurnal Istiqro', (vol. 04, no. 01/2006), hlm. 96-107.

Zainiyati, Husniyatus Salamah, "Pesantren Mahasiswa Transformatif sebagai Upaya Pemberdayaan Mahasiswa PTAI", Jurnal Menara Tebuireng, (vol. 3, no.1/September 2006), hlm. 92-102.

Ziemeck, Manfred, Pesantren dalam Perubahan Sosial, (Jakarta: P3M, 1986). 


\title{
Problem dan Solusi Studi Mahasiswa Semester Tua
}

\author{
Raharjo \\ IAIN Walisongo Semarang \\ E-mail: joe.raharjo65@yahoo.co.id
}

\begin{abstract}
This paper describes the problems of old-semester students in completing their study at the Faculty of Science of Islamic Education and Teaching (FITK) IAIN Walisongo Semarang. The study of exploratory qualitative approach involves 20 students from all courses taken by purposive random sampling with the technique of questionnaires, interviews and documentations. The results are: (1) The problems faced by elderly semester students is a matter of academic and nonacademic, namely working part time, participating organizations, teaching and unwarranted. (2) The problems are handled by the leaders of the faculty involved: (a) anticipatory since the beginning of their study and academic orientation; (b) preventing for their study by the lecturer as supervisor; and (c) curating towards the end of the study by the head of the faculty. These steps are performed in order to provide opportunities for students to be able to pass and not threatened to drop out.
\end{abstract}

Keywords: delayed study, old students, solutions, anticipatory, preventive and curative

\begin{abstract}
Abstrak
Paper ini menjelaskan permasalahan mahasiswa semester tua dalam menyelesaikan studinya di Fakultas Ilmu Tarbiyah dan Keguruan (FITK) IAIN Walisongo Semarang. Kajian dengan pendekatan kualitatif eksploratif ini melibatkan 20 mahasiswa dari semua program studi yang diambil secara purposive random sampling dengan teknik angket, wawancara, dokumentasi. Hasilnya adalah bahwa: (1) Mahasiswa semester tua menghadapi masalah akademik dan nonakademik berupa kuliah kerja, ikut organisasi, mengajar dan tidak beralasan. (2) Penanganan yang dilakukan pimpinan lembaga meliputi: (a) antisipatif sejak awal masa studi dan orientasi akademik; (b) preventif selama studi oleh dosen pembimbing; dan kuratif menjelang akhir studi oleh pimpinan lembaga. Langkah-langkah ini dilakukan dalam rangka memberikan peluang kepada mahasiswa agar bisa lulus dan tidak terancam drop out.
\end{abstract}

Kata kunci: keterlambatan studi, mahasiswa semester tua, solusi, antisipatif, preventif dan kuratif 


\section{A. Pendahuluan}

Pencapaian tujuan merupakan standar keberhasilan suatu usaha, sehingga setiap usaha yang dilakukan berdasarkan tujuan tertentu, pasti ditargetkan untuk mencapai tujuan tersebut. Dalam konteks pendidikan, keberhasilan itu didasarkan pada standar kelulusan yang kemudian kita kenal dengan istilah output. Standar keberhasilan pendidikan di perguruan tinggi ditandai dengan perolehan skor lulus pada tiap mata kuliah. Skor-skor tersebut diakumulasikan dan di rata-rata menjadi indeks prestasi (IP). IP untuk satu semester disebut IP semester, sedangkan IP selama masa studi yang sudah ditempuh disebut IP kumulatif.

Target selesainya masa studi secara teoritis tersebut memberikan kesan bahwa kuliah itu ringan dan memang dapat diselesaikan selama 8 semester. Dikatakan ringan, karena dengan mengambil beban studi 20 SKS dalam satu semester, beban belajar per Minggu hanya 10 kali tatap muka. Jika sehari ada 3 kali tatap muka, misalnya jam pertama hingga jam ketiga (mulai jam 07:00 hingga jam 11:50), maka tiap pekan hanya diperlukan 4 hari untuk memenuhi kuliah tatap muka di kelas. Sisa waktunya dapat digunakan untuk belajar mandiri (kurikuler, kokurikuler dan/ekstrakurikuler), kegiatan lain, atau bahkan dapat digunakan untuk kerja casual (sambilan). Dengan demikian, pengambilan beban studi 20 SKS per semester tersebut sebenarnya tidak semata-mata didasarkan pada kemampuan kognitif (IQ) mahasiswa, namun lebih didasarkan pada rencana kuliah yang dipadu dengan kegiatan-kegiatan lainnya.

Kenyataan di lapangan, banyak mahasiswa pada semester 2 sampai 6, mengambil mata kuliah 24 SKS, dengan demikian, secara teoritis, beban studi mereka pada semester 7 dan 8 sangat ringan, namun tetap saja ada di antara mereka yang menyelesaikan studinya lebih dari 5 tahun. Di sisi lain, sebagian mahasiswa yang lulus hingga semester 12, memang sudah mengatur beban belajarnya sedemikian rupa. Di samping belajar, mereka aktif di kegiatan ekstra kurikuler atau sambil bekerja. Dengan demikian, secara umum mahasiswa yang masa studinya melebihi 10 semester dimungkinkan memiliki kendala. Kendala tersebut tentunya kendala nonakademik, sebab jika mahasiswa tersebut mengalami kendala akademik, kemungkinan sudah terkena DO (drop out) pada akhir semester dua dengan perolehan IP kumulatif 
di bawah 2,0 atau dengan sendirinya keluar akibat ketidakmampuan menyelesaikan tugas-tugas akademik. ${ }^{1}$

Pertanyaannya adalah mengapa masih ada mahasiswa yang masa studinya melebihi semester 10? Masalah apa yang mereka hadapi? Solusi apa yang bisa diberikan, agar mereka tidak melewati batas maksimal masa studinya? Inilah fenomena yang menarik untuk dilakukan penelitian, agar diperoleh solusi terbaik guna membantu kelancaran studi dan peningkatan kualitas prestasi mahasiswa.

\section{B. Keterlambatan Studi Di Perguruan Tinggi}

1. Kajian Teori

Masa studi S.1 diberi waktu paling lama 14 semester dengan beban studi maksimal 160 sks. Secara praktis, beban studi tersebut dapat diselesaikan selama 9 semester, sebagaimana deskripsi di atas, dengan wisuda di semester 10 . Dengan demikian mahasiswa yang menyelesaikan studi lebih dari semester 10 dapat dikategorikan mahasiswa dengan problem 'keterlambatan studi'.

Definisi problem keterlambatan studi tersebut diperkuat dengan Permendikbud Nomor 49 Tahun 2014 tentang Standar Nasional Pendidikan Tinggi yang mengatur S1 dengan beban studi 144 SKS (Pasal 17) dan masa usia studi 4-5 tahun. ${ }^{2}$ Isi Permendikbud tersebut dapat dipahami bahwa mahasiswa S1 yang masa studinya lebih dari 5 tahun, dapat dikatakan terlambat. Dengan kata lain, mereka yang masa studinya berada di semester 11 sampai dengan 14 termasuk mahasiswa semester tua, sebagaimana topik penelitian ini.

a. Problem Studi di Perguruan Tinggi

Studi di perguruan tinggi merupakan salah satu citacita siswa-siswi SMA/sederajat. Studi di perguruan tinggi dibedakan dari studi di tingkat pendidikan yang lebih rendah (sekolah/ madrasah) didasarkan pada tiga aspek, yaitu: usia peserta didik, tujuan belajar dan lama belajarnya. Usia peserta didik berada pada rentang usia

${ }^{1}$ IAIN Walisongo, Buku Panduan Program Sarjana (S.1) dan Diploma 3 (D.3), tahun akademik 2013-2014, hlm.177-178.

2 Permendikbud Nomor 49 Tahun 2014 tentang Standar Nasional Pendidikan Tinggi. 
dewasa, karenanya sistem pembelajaran di perguruan tinggi menggunakan model andragogi. Tanggung jawab belajar hampir sepenuhnya dipercayakan kepada mahasiswa, sedangkan dosen hanya memberikan dasardasar pengetahuan saja.

Tujuan belajar di perguruan tinggi adalah untuk memantapkan mahasiswa menjadi seorang pekerja di kemudian hari yang lebih terampil dan profesional. Untuk memberikan keleluasaan dan fleksibilitas beban dan aktivitas kuliah, maka diberlakukan sistem kredit semester (sks). Lama belajar di perguruan tinggi untuk program S-1 dan D-IV adalah antara 8 semester (4 tahun) hingga 14 semester (7 tahun) dengan beban studi 144-160 sks. Aturan baru tentang lama belajar di perguruan tinggi untuk program S-1 dan D-IV adalah 4-5 tahun. ${ }^{3}$

Pada awalnya, para alumni SMA berusaha semaksimal mungkin bisa diterima di Perguruan Tinggi Negeri. Berbagai jalur diikutinya, dari seleksi nasional, tes nasional, hingga jalur mandiri di perguruan tinggi masing-masing. Lebih-lebih dengan diberlakukannya UKT (uang kuliah tunggal), biaya kuliah di perguruan tinggi negeri favorit bukan satu hal yang menghantui. Mereka yang tidak diterima di PTN, dapat masuk di PTS (perguruan tinggi swasta) yang jumlah program studinya lebih banyak dan kualitasnya tidak selalu lebih rendah dari program studi di PTN. ${ }^{4}$

Sebagai mahasiswa baru, mereka melangkahkan kaki menuju kampus dengan bangga dan semangat, serta berharap dapat menyelesaikan kuliah dengan cepat untuk segera menjadi seorang sarjana atau seorang profesional dalam bidang tertentu. Setelah beberapa Minggu mengikuti perkuliahan, mereka merasakan ternyata belajar di Perguruan Tinggi tidaklah semudah yang

${ }^{3}$ Permendikbud Nomor 49 Tahun 2014 tentang Standar Pendidikan Tinggi, Pasal 17 poin 3.

${ }_{4}^{4}$ Peraturan Menteri Pendidikan dan Kebudayaan (Permendikbud) No. 55 Tahun 2013 tertanggal 23 Mei 2013, tentang Biaya Kuliah Tunggal (BKT) dan Uang Kuliah Tunggal (UKT) pada Perguruan Tinggi Negeri (PTN) di lingkungan Kementerian Pendidikan dan Kebudayaan (Kemdikbud). 
mereka bayangkan. Mereka harus mengikuti perkuliahan dengan tertib, rajin membaca literatur-literatur yang mungkin berbahasa asing, memahami berbagai macam teori, mengerjakan tugas-tugas, menyusun makalah, presentasi, berdiskusi dan sebagainya.

Mahasiswa yang kurang cepat beradaptasi dengan atmosfer perguruan tinggi sering merasa kurang siap menghadapi tugas-tugas akademiknya (sehingga dianggap sebagai beban atau masalah yang sangat berat), yang bisa berakibat pada perolehan skor rendah (atau bahkan tidak lulus) pada satu atau beberapa mata kuliah. Masalah-masalah lainnya yang dapat dipersepsikan amat beragam, antara lain: mata kuliah tertentu dianggap asing, susah memahami literatur, lambat menyelesaikan tugas, menyusun makalah tidak sempurna, berbicara di kelas ditertawakan temannya. Efeknya bisa tidak kerasan kuliah di suatu program studi (prodi) dan ingin pindah ke lain prodi, lulus tidak tepat waktu (lebih dari 5 tahun), lulus tidak cumlaude, lulus dengan IP pas-pasan, ataupun lulus tapi tidak segera mendapat pekerjaan. ${ }^{5}$ Dalam aturan baru, masa studi di perguruan tinggi (S-1 dan DIV) dibatasi paling lama 5 tahun. ${ }^{6}$ Walaupun masih banyak mendapat respons negatif dari berbagai perguruan tinggi. ${ }^{7}$ Terutama dari perguruan tinggi swasta. ${ }^{8}$

b. Strategi Studi di Perguruan Tinggi

Dalam menghadapi rangkaian masalah studi di perguruan tinggi, mahasiswa memerlukan strategi tertentu agar dapat mengatur waktu, dana, tenaga, kegiatan, fasilitas, dan penyelesaian studinya. Strategi

${ }^{5}$ Daniel Mohammad Rosyid, Sukses Kuliah di Perguruan Tinggi, Siapa Takut?, (http:// danielrosyid. com/ buku-baru-sukses-kuliah-di-perguruantinggi-siapa-takut.html), Diakses 10 Januari 2015.

6 Permendikbud Nomor 49 Tahun 2014 tentang Standar Pendidikan Tinggi, Pasal 17 poin 3.

${ }^{7}$ Edzan Raharjo, Masa Kuliah Dibatasi Maksimal hanya 5 Tahun, Mahasiswa UGM Unjuk Rasa, (http://news.detik.com/read/2014/09/16/ 125853/2691572/10/masa-kuliah-dibatasi-maksimal-hanya-5-tahunmahasiswa-ugm-unjuk-rasa), diakses 16 September 2014.

${ }^{8}$ Hendy Kurniawan, Kuliah Dibatasi Hanya 5 Tahun, (http://jogja. tribunnews.com /2014/ 09/05/kuliah-dibatasi-hanya-5-tahun/), diakses 05 September 2014. 
tersebut dilandasi dengan semangat, tekun dan giat belajar agar dapat mencapai tujuan yang ditetapkan sebelumnya. ${ }^{9}$ Satu strategi kuliah yang dapat diaplikasikan oleh mahasiswa adalah sistem belajar "MURDER" dari buku The Complete Problem Solver oleh Bob Nelson. ${ }^{10}$ Istilah tersebut dijabarkan dalam beberapa kata yakni: Mood-Understand-Recall-DigestExpand-Review. Setiap mahasiswa harus menciptakan perasaan senang (mood) setiap kali menerima materi kuliah. Setiap catatan perlu diberi tanda pada kalimat atau kata yang tidak dapat dipahami, lalu dicari jawaban dan penjelasannya melalui sumber-sumber lain untuk meningkatkan pemahaman (understand).

Materi yang telah dipelajari perlu diulang (recall) secara kontinu, baik dengan cara membuat rangkuman dengan kata-kata sendiri ataupun menggunakan kata kunci dari setiap kalimat yang panjang. Rangkuman yang telah dibuat perlu ditelaah kembali (digest) dan apabila kurang jelas bisa mencari penjelasan lebih lanjut dari dosen atau sumber lainnya atau berdiskusi dengan teman. Materi yang telah dipelajari perlu dikembangkan (expand) dan diterapkan dalam kehidupan diri sendiri. Lalu didiskusikan dengan teman atau dosen berdasarkan catatan dan atau materi yang dipelajari sebelumnya. Materi-materi yang telah dipelajari harus dipelajari kembali (review) dan jangan pernah bosan untuk mengulang materi yang sudah dibaca agar semakin mudah diingat dan dipahami.

Strategi lainnya yang berdampak pada pencapaian prestasi akademik bagi mahasiswa dalam proses belajarnya adalah: (1) Jadwal perlu disusun dengan cermat dalam melakukan setiap kegiatan, agar tidak membuang-buang waktu. (2) Setiap mahasiswa harus belajar untuk membuat tujuan kegiatan akademik dan menjalankan tujuan tersebut dengan strategi tepat. (3)

9 Aty Nurdiana, Cara Belajar di Perguruan Tinggi, (http://lentera stkippgribl.blogspot.Com/2013/02/cara-belajar-di-perguruan-tinggi.html), diakses 11 Januari 2014.

10

http://www.nyit-nyit.net/topic/55025-cara-belajar-efektif-diperguruan-tinggi/ 
Kegiatan pembelajaran harus ditempatkan sebagai prioritas utama, baru untuk kegiatan yang lain. (4) Mahasiswa harus menghadiri setiap kegiatan kuliah dari awal hingga akhir. (5) Tiap mahasiswa harus dapat meluangkan waktu untuk belajar secara efektif dengan mendalami materi yang telah dipelajari dan mempelajari ulang, secara mandiri atau kelompok. (6) Membina hubungan dengan pembimbing akademik dengan komunikasi rutin yang efektif akan membantu memperlancar proses pembelajaran. ${ }^{11}$ (7) Setiap dosen memiliki sifat, sikap dan karakter, yang berbeda dengan dosen yang lain, dan mahasiswa perlu memahami dosennya masing-masing. (8) Mahasiswa perlu memahami dan mematuhi peraturan dan kebijakan perguruan tinggi. (9) Sarana dan prasarana kampus disediakan untuk mendukung proses dan pelayanan kegiatan akademik, untuk itu mahasiswa perlu memahami ketersediaannya, dan dapat memanfaatkannya secara optimal. (10) Kegiatan nonakademik sangat berperan dalam mengembangkan bakat dan kepribadian. Kegiatan nonakademik disediakan untuk mahasiswa guna mempersiapkan peran sosialnya di masyarakat. Peranan sosial mahasiswa dan pemuda di masyarakat, kurang lebih sama dengan peran warga yang lainnya di masyarakat. $^{12}$

c. Faktor yang Mempengaruhi Keberhasilan Kuliah

Beberapa tokoh (Dimyati Mahmud, Rooijakkers, Ngalim Purwanto), mengatakan bahwa faktor-faktor yang mempengaruhi prestasi belajar siswa secara umum dapat dibagi dua yakni faktor internal dan faktor eksternal. ${ }^{13}$

1) Faktor Internal

${ }^{11}$ Aghnia, Strategi Belajar Di Perguruan Tinggi, (http://aghnia-rahmah. blogspot. com/2011/10/ strategi-belajar-di-perguruan-tinggi.html), diakses: 10 Januari 2015.

12 Abdul Hakim, Memahami \& menghayati masalah-masalah kepemudaan, sebagai pemuda yang sedang belajar di perguruan tinggi, (http://alhakiiim.blogspot.com/2012/11/memahami-menghayati-masalahmasalah_13.html), diakses 10 Januari 2015.

13 Ngalim Purwanto, Psikologi Pendidikan, (Bandung: Remaja Rosdakarja, 1990), hlm. 270. 
Faktor internal adalah faktor yang berasal dari dalam diri siswa itu sendiri. Faktor ini meliputi biologi, fisiologi dan psikologi. ${ }^{14}$ Faktor biologi berupa bakat, minat, dan kecerdasan yang diturunkan secara genetik dari orang tuanya dan sifatnya relatif permanen. Faktor fisiologi berupa kondisi fisik dan pancaindra. 15 Sedangkan faktor psikologi mencangkup (a) need for achievement yaitu kebutuhan atau dorongan atau motif untuk berprestasi, (b) interest yakni minat terhadap sesuatu, dan (c) capability, berupa bakat dan kecerdasan seperti kemampuan memusatkan perhatian pada materi perkuliahan yang berlangsung, tingkat penerimaan dan pengingatan bahan, kemampuan menerapkan apa yang dipelajari, kemampuan mereproduksi dan kemampuan menggeneralisasi.

Ada empat modal utama yang mempengaruhi keberhasilan studi di perguruan tinggi, yaitu: citacita, minat, percaya diri dan kebebasan jiwa. Setiap mahasiswa yang belajar di Perguruan Tinggi harus didukung oleh cita-cita tertentu, sehingga ia tahu tujuan yang harus dicapai dan tahu untuk apa ia belajar. Seorang mahasiswa harus mempunyai minat tinggi terhadap setiap mata kuliah yang diikuti, agar ia merasa senang dalam mengikuti perkuliahan sehingga dapat berkonsentrasi dan memperkecil kegagalan. Mahasiswa harus memiliki rasa percaya diri bahwa ia tidak berbeda dengan teman-temannya, sehingga tidak minder. Di samping itu mahasiswa juga harus memiliki kebebasan jiwa, yang memungkinkan dia terbebas dari pengaruh sentimen dan emosi, dan tetap memiliki sikap ilmiah dan dapat berpikir kritis. ${ }^{16}$ 84-87.

${ }^{14}$ M.D. Mahmud, Psikologi Pendidikan, (Jakarta: PPLPTK, 1989), hlm.

15 A. Rooijakers, Mengajar dengan Sukses, terj. Soenoro, (Jakarta: Gramedia,1982), hlm. 30.

16 Aty Nurdiana, Cara Belajar di Perguruan Tinggi, (http://lenterastkippgribl. blogspot. Com /2013/02/cara-belajar-di-perguruantinggi.html), diakses 11 Januari 2015. 
Faktor-faktor internal tersebut berujud dalam bentuk gaya belajar, yang tentunya berbeda dengan gaya belajar siswa di SLTA. ${ }^{17}$ Mahasiswa dituntut untuk mampu belajar mandiri baik secara individual maupun kelompok dalam perkuliahan, dan mengusai sumber-sumber informasi dan perkuliahan baik di perpustakaan maupun internet. Mahasiswa harus mampu mendisiplinkan diri untuk belajar baik di rumah atau kos dan di kampus. Belajar kelompok akan memberikan percepatan belajar karena ada interaksi sesama mahasiswa. Sebelum perkuliahan, mahasiswa harus sudah mempersiapkan diri baik mental maupun kesiapan mempelajari bahan perkuliahan. Selama perkuliahan mahasiswa harus mampu untuk aktif dalam berinteraksi dengan mahasiswa lainnya maupun dengan dosen. ${ }^{18}$

2) Faktor Eksternal

Faktor eksternal adalah faktor yang berasal dari luar diri mahasiswa. Faktor ini meliputi: (a) lingkungan alam dan sosial baik itu lingkungan keluarga, kampus maupun masyarakat, dan (b) instrumentasi yang berupa kurikulum, dosen, sarana dan fasilitas serta administrasi.

Faktor dominan di lingkungan kampus adalah dosen, mahasiswa dan pegawai. Mahasiswa harus bisa menjaga dan membina hubungan baik dengan dosen. Hubungan ini akan menambah kualitas interaksi akademik dalam upaya menambah dan memperdalam wawasan dan pengetahuan baik dalam bidang akademik maupun nonakademik. Dosen dapat berperan sebagai pejabat struktural, pembimbing akademik, pembimbing kemahasiswaan, pembimbing kegiatan praktek lapangan dan sebagai pengajar. Oleh karena itu, mahasiswa perlu menyesuaikan diri dengan setiap

17 Abdul Muiz Lidinillah, Strategi Belajar di Perguruan Tinggi (PT), (http://dindin-abdulmuiz. blogspot. Com /2008/09/strategi-belajar-diperguruan-tinggi-pt.html), diakses 10 Januari 2015.

${ }^{18}$ IAIN Walisongo, Buku Panduan Program Sarjana (S.1) dan Diploma 3 (D.3), tahun akademik 2013-2014, hlm.71 
peran dari dosen tersebut demi keberhasilan kuliahnya. $^{19}$

Keaktifan dalam kegiatan kemahasiswaan merupakan sarana pendukung untuk membina hubungan sosial mahasiswa dengan mahasiswa. Sejak mulai menjadi mahasiswa baru, mahasiswa sudah dapat melibatkan diri dalam setiap kegiatan kemahasiswaan. Dimulai dengan kegiatan orientasi pengenalan kampus, hingga kegiatan ekstra kurikuler serta kegiatan-kegiatan di luar kampus, kesemuanya untuk menambah horizon pengalaman mahasiswa. Pemilihan jenis kegiatan nonakademik bisa berpengaruh (positif-negatif) terhadap studi.

Sebagian mahasiswa berhasil membagi waktu dengan kegiatan kuliah, sebagian lain terganggu kuliahnya. Namun, ada juga mahasiswa yang tidak mendapatkan sesuatu dari beraktivitas dalam kegiatan kemahasiswaan. Sebelum menentukan pilihan kegiatan tersebut, mahasiswa harus terlebih dahulu memahami tujuan untuk aktif, bisa didasarkan pada minat dan bakat atau karena tujuan untuk mengembangkan diri dalam bidang organisasi. Mahasiswa harus terlebih dahulu memahami segala konsekuensi ke depan baik dari segi waktu, biaya atau pengaruhnya terhadap tugas kuliah.

Mahasiswa akan sering berinteraksi dengan masyarakat baik di dalam maupun di luar kampus. Di kampus ada pegawai administrasi sebagai pihak yang berperan dalam memperlancar prosedurprosedur akademik, juga warga kampus lainnya seperti pedagang. Masyarakat di luar kampus seperti di lingkungan tempat tinggal menjadi bagian yang sering membantu kelancaran studi di perguruan tinggi. Pemilihan tempat kos atau asrama hendaknya yang strategis dilihat dari kondusif tidaknya terhadap kegiatan belajar. Mahasiswa dapat berinteraksi

\footnotetext{
${ }^{19}$ Abdul Muiz Lidinillah, Strategi Belajar di Perguruan Tinggi (PT), (http://dindin-abdulmuiz.blogspot.com/2008/09/strategi-belajar-diperguruan-tinggi-pt.html), diakses 10 Januari 2015.
} 
secara luas dengan masyarakat selama menunjang pada program perkuliahan dan membantu dalam pengembangan diri mahasiswa.

Deskripsi di atas menunjukkan bahwa problem belajar di perguruan tinggi dapat dibedakan menjadi dua yakni problem akademik dan nonakademik. Problem akademik adalah problem yang terkait dengan aktivitas kuliah mencakup perencanaan, proses dan hasil.. Problem nonakademik adalah problem di luar aktivitas kuliah, tetapi terkait dengan keseluruhan proses pembentukan sikap, kepribadian dan perilaku mahasiswa sebagai bagian dari tujuan pendidikan di perguruan tinggi. Masalah nonakademik tersebut antara lain keuangan, asmara, keluarga, sosial, dan karier.

2. Kajian Hasil Penelitian Sebelumnya

Aditya Sukma, Studi Empiris Pengaruh Kecerdasan Emosional, Perilaku Belajar, dan Stres Kuliah terhadap Keterlambatan Penyelesaian Studi (Studi pada Mahasiswa S1 Akuntansi Universitas Brawijaya Malang). ${ }^{20}$ Penelitian ini dimaksudkan untuk mencari jawaban atas fenomena lama penyelesaian studi dan keterkaitannya dengan variabel kecerdasan emosional, perilaku belajar, dan tingkat stres mahasiswa. Populasi penelitian ini adalah mahasiswa Jurusan Akuntansi Universitas Brawijaya Malang, yang telah menempuh masa studi lebih dari 4 tahun (8 semester). Teknik pengambilan sampel menggunakan purposive sampling. Data penelitian diperoleh melalui kuesioner.

Penelitian ini dilakukan dengan menggunakan analisis regresi linear berganda. Hasil penelitian menunjukkan bahwa variabel perilaku belajar dan stres kuliah berpengaruh signifikan terhadap keterlambatan penyelesaian studi, sedangkan variabel kecerdasan emosional tidak berpengaruh secara signifikan.

${ }^{20}$ A. Sukma, Studi Empiris Pengaruh Kecerdasan Emosional, Perilaku Belajar, dan Stres Kuliah terhadap Keterlambatan Penyelesaian Studi (Studi pada Mahasiswa S1 Akuntansi Universitas Brawijaya Malang), http://jimfeb.ub.ac.id/index.php/jimfeb/article/view/707/649, diakses 1 Oktober 2014. 
Yahdinil Firda Nadirah (2011), Hubungan Antara Stres dan Bersyukur dengan Keterlambatan Penyelesaian Studi pada Mahasiswa (Studi pada Mahasiswa yang Mengalami Keterlambatan Penyelesaian Studi di Fakultas Tarbiyah IAIN "SMH" Banten). ${ }^{21}$ Sampel penelitian ini berjumlah 30 orang mahasiswa IAIN "SMH" Banten di lingkungan Fakultas Tarbiyah yang berada pada semester 9 atau lebih, yang diperoleh berdasarkan teknik purposive sampling.

Berawal dari penelitian, ditemukan adanya hubungan yang signifikan antara stres dan keterlambatan penyelesaian studi mahasiswa sebesar $\mathrm{p}=0.023(\overline{\mathrm{p}} 0.05)$. Semakin tinggi stres yang dialami seorang mahasiswa maka semakin terlambat penyelesaian studinya. Sementara tidak ditemukan adanya hubungan yang signifikan antara bersyukur dengan keterlambatan penyelesaian studi pada mahasiswa. Dan hipotesis yang menyatakan adanya kontribusi yang positif dan signifikan antara kedua variabel (stres dan bersyukur) dengan keterlambatan penyelesaian studi pada mahasiswa, ditolak. Kedua variabel tersebut (stres dan bersyukur) secara bersama-sama tidak memberikan kontribusi yang signifikan terhadap keterlambatan penyelesaian studi pada mahasiswa.

Anis Ardiana Kurniawati (2011), Analisis ProblemProblem Keterlambatan Penyelesaian Studi Mahasiswa di STAIN Salatiga (Studi Kasus Mahasiswa Program Studi Pendidikan Agama Islam Tahun Ajaran 2004 dan 2005). ${ }^{22}$ Permasalahan yang diteliti adalah faktor-faktor

21 Y.F. Nadirah, Hubungan Antara Stres dan Bersyukur dengan Keterlambatan Penyelesaian Studi pada Mahasiswa (Studi pada Mahasiswa yang Mengalami Keterlambatan Penyelesaian Studi di Fakultas Tarbiyah IAIN "SMH" Banten), http://iainbanten.ac.id/berita-314-hubungan-antarastress-dan-bersyukur-dengan-keterlambatan-penyelesaian-studi-padamahasiswa.html, diakses 1Oktober 2014.

22 A.A. Kurniawati, Analisis Problem-Problem Keterlambatan Penyelesaian Studi Mahasiswa di STAIN Salatiga (Studi Kasus Mahasiswa Program Studi Pendidikan Agama Islam Tahun Ajaran 2004 dan 2005), http://eprints.stainsalatiga.ac.id/659/1/ANALISIS\%20PROBLEM-

PROBLEM\%20KETERLAMBATAN\%20 PENYELESAIAN\%20STUDI\% 20-STAIN\%20SALATIGA.pdf, diakses 1 Oktober 2014. 
penyebab keterlambatan dan solusi untuk mengatasi permasalahan keterlambatan penyelesaian studi. Penelitian ini menggunakan pendekatan kualitatif deskriptif, sedangkan pengumpulan datanya menggunakan metode wawancara dan dokumentasi.

Hasil penelitian menunjukkan bahwa pada faktor eksternal problem yang dialami oleh mereka adalah ekonomi keluarga, sedangkan pada faktor internal problem yang dialami adalah inteligensi, kepribadian, minat sekolah, adaptasi, sifat dan motivasi. Solusi untuk mengatasi permasalahan tersebut di atas bersumber dari alumni mahasiswa Program Studi PAI tahun ajaran 2006 dan beberapa dosen serta pejabat STAIN Salatiga yang berkecimpung pada Program Studi Pendidikan Agama Islam (PAI).

\section{Metode Penelitian}

Penelitian ini menggunakan metode penelitian kualitatif eksploratif. Di mana peneliti melakukan penjajakan terhadap kondisi mahasiswa yang masuk semester tua (semester 12 dan 14) di Fakultas Ilmu Tarbiyah dan Keguruan (FITK) IAIN Walisongo Semarang. Metode ini dapat memberikan sebuah gambaran mengenai kondisi yang terjadi sebenarnya oleh mahasiswa, apa saja yang dialami selama menjadi mahasiswa, termasuk mencari jalan keluar terhadap persoalan yang ada. ${ }^{23}$

Data mahasiswa semester 12 dan 14 yang tercatat sebagai mahasiswa aktif di IAIN Walisongo pada semester gasal 20132014 berjumlah 308, dengan rincian sebagai berikut:

\begin{tabular}{lccc}
\hline \multirow{2}{*}{ Fakultas } & Masuk Th 2007 & Masuk Th 2008 & \multirow{2}{*}{ Jumlah } \\
\cline { 2 - 3 } & SMT 14 & SMT 12 & \\
\hline FDK & 17 & 42 & 59 \\
\hline FS & 14 & 36 & 50 \\
\hline FEBI & 9 & 23 & 32 \\
\hline FITK & 54 & 82 & 136 \\
\hline
\end{tabular}

${ }^{23}$ Keputusan Rektor IAIN Walisongo tentang Mahasiswa Aktif, Lulus, Cuti, dan Dicutikan serta diberhentikan sebagai mahasiswa pada Semester Genap Tahun Akademik 2013-2014. 


\begin{tabular}{llcc}
\hline FU & 5 & 26 & 31 \\
\hline & Total & & 308 \\
\hline
\end{tabular}

Dari data tersebut diketahui bahwa mahasiswa semester tua yang ada di FITK berjumlah 136 orang. Mahasiswa tersebut pada umumnya telah selesai kuliah teori, sehingga aktivitasnya di kampus menjadi jarang. Teknik yang dilakukan peneliti untuk dapat mengumpulkan data adalah bekerja sama dengan wakil dekan bidang akademik, wakil dekan bidang kemahasiswaan dan beberapa pimpinan program studi. Wakil dekan menyebarkan undangan kepada para mahasiswa semester 12 dan 14 tersebut untuk dilakukan pembinaan, namun responsnya sangat tidak menggembirakan karena hanya ada 5 orang yang datang memenuhi undangan tersebut. Melalui pimpinan program studi, beberapa mahasiswa bisa ditemui saat mereka mengajukan judul dan atau bimbingan skripsi. Responden yang dapat direkrut dalam penelitian ini adalah 20 orang. Dengan demikian, sampling yang digunakan dalam penelitian ini adalah purposive sampling.

Data-data penelitian ini dikumpulkan dengan beberapa teknik, yakni (1) Angket, diberikan kepada mahasiswa untuk mengumpulkan data tentang problema umum yang mereka hadapi. (2) Wawancara, dilakukan kepada mahasiswa tersebut untuk mengumpulkan data lebih detail mengenai kendala-kendala yang mereka hadapi dalam penyelesaian kuliah. Wawancara juga dilakukan kepada pimpinan Fakultas terutama wakil dekan (WD) 1 dan 3 bidang akademik dan kemahasiswaan, di samping itu juga beberapa pimpinan program studi. (3) Dokumentasi, digunakan untuk mengumpulkan data tentang jumlah mahasiswa semester 12 dan 14 yang berada di FITK IAIN Walisongo Semarang, sebagaimana disajikan pada tabel di atas.

Setelah semua data terkumpul, maka dilakukan analisis data dalam bentuk analisis deskriptif naratif logis melalui pola development studies. ${ }^{24}$ Pola analisis tersebut memudahkan untuk menemukan keadaan dan tahapan-tahapan problem belajar mahasiswa. Selain itu, dapat dianalisis kemampuan mahasiswa dalam menyelesaikan perkuliahannya agar tidak mengalami drop

${ }^{24}$ Nana Saodih Sukmadinata, Metode Penelitian Pendidikan, (Bandung: Remaja Rosdakarya, 2010), hlm. 77. 
out. Di situlah akan didapatkan solusi-solusi mendalam mengenai masalah-masalah yang ditemui ini.

\section{Hasil Penelitian Dan Pembahasan}

Semua orang selalu mengharapkan untuk sukses dan lancar dalam menjalankan seluruh apa yang dicita-citakan, termasuk di dalamnya adalah pelaksanaan kuliah. Dosen bertugas untuk mengajar, mahasiswa belajar, sedangkan pihak birokrasi melayani segala proses administrasi perkuliahan sesuai aturan-aturan yang ditetapkan. Namun, selama proses berjalannya kuliah, permasalahan selalu saja terjadi. Keberhasilan dalam melaksanakan suatu tugas merupakan dambaan setiap orang. Berhasil berarti terwujudnya harapan. Perlu disadari, bahwa pada dasarnya setiap tugas atau aktivitas selalu berakhir pada dua kemungkinan: berhasil atau gagal.

1. Masalah-masalah yang Dihadapi Mahasiswa

Masalah yang dihadapi oleh mahasiswa Fakultas Ilmu Tarbiyah dan Keguruan IAIN Walisongo yang didapatkan dalam penelitian ini sangat beragam. Hal ini nampak dari kendala-kendala yang dirasakan oleh mahasiswa selama menjalankan aktivitas perkuliahan. Sejak pertama kali, mahasiswa masuk ke IAIN Walisongo dengan motivasi yang berbeda-beda. Berdasarkan data yang diperoleh, mayoritas masuk kuliah atas inisiatif diri sendiri (80\%), ada juga yang masuk kuliah karena dorongan orang tua (10\%) dan jalan keluar tidak diterima di Perguruan Tinggi Negeri lain (10\%). Ini menunjukkan bahwa masih ada $20 \%$ minat mahasiswa memilih jurusan itu bukan atas inisiatifnya sendiri, yang berpotensi menjadikannya tidak bisa merasakan basis keilmuan sejak pertama masuk kuliah. Maka dari itu, potensi untuk berkuliah dengan masalah akademik yang dihadapi terkadang muncul atas dasar dirinya merasa tidak menguasai materi-materi perkuliahan.

Data lain menunjukkan bahwa program studi pilihan mahasiswa lebih banyak dimotivasi untuk mencari ilmu (80\%), sebagian lainnya menuruti pilihan orang tua (10\%) dan alternatif prodi lainnya (10\%). Maka dari itu, ketika mahasiswa memang merasakan bahwa pilihan studinya itu tepat, perkuliahan dapat berjalan dengan baik dan lancar. Berbeda halnya dengan mahasiswa yang minat studinya atas 
dasar dorongan orang tua dan akibat pilihan alternatif, akan mengakibatkan dirinya mengalami kendala di proses perkuliahannya.

Proses penyelesaian kuliah teori dan praktik bagi mahasiswa semester tua ini sangat bervariasi. Dari selesai semester 8 s/d 14 (akhir semester masih menjalani kuliah ulang). Ini merupakan cerminan bahwa tidak semua mahasiswa mempunyai rencana kuliah yang sama akibat beban SKS yang dapat diambil berdasarkan nilai HSS yang dimilikinya. Sehingga di antara mereka ada yang bisa kuliah cepat dan ada yang merasakan kuliah dengan waktu yang sangat panjang. Dari hasil angket yang dibagikan dan wawancara dengan mahasiswa semester 12 dan 14 di lingkungan FITK IAIN Walisongo Semarang, mahasiswa menunda kelulusan mempunyai alasan: (1) Kerja, (2) Organisasi, (3) Mengajar, dan (4) Menganggur (tidak beralasan).

Data dari hasil wawancara terhadap mahasiswa semester tua yang belum selesai perkuliahannya dikarenakan berbagai hal. Dewi, jurusan PAI (Pendidikan Agama Islam) semester 13, baru saja mengajukan judul ke jurusan pada bulan September 2014. Problem penghambatnya, karena sekarang ia sudah menikah, sudah dikaruniai anak, dan tinggal di Rembang. Jarak antara Semarang dan Rembang dianggap jauh $( \pm 128$ KM $)$ sehingga sering dianggap sebagai penghambat untuk bisa melakukan komunikasi dengan kampus secara intensif.

Kasus yang sama juga dialami oleh Suasana, jurusan TBI (Tadris Bahasa Inggris). Mahasiswi semester 13 ini mengaku bahwa problem berkeluarga yang sekarang telah dikaruniai anak ini, sungguh menyita perhatian yang besar, sehingga kuliahnya merasa kurang mendapat perhatian. Jarangnya bertemu dan berkomunikasi dengan teman-teman dan juga kampus mengakibatkan ia terlelap dengan persoalan yang dihadapinya.

Hal ini dapat dimaklumi, karena ia merupakan mahasiswa pindahan dari Perguruan Tinggi lain, pada semester 13 ini ia sedang mengurus bimbingan dengan ketua jurusan Bahasa Inggris Siti Tarwiyah, dan ketika beliau dikonfirmasi oleh peneliti juga belum menunjukkan kemajuan yang maksimal. 
Berbeda dengan Fatimatuzzahro, mahasiswi PAI angkatan 2008 ini di samping memiliki problem keluarga, ia juga mengaku merasa kesulitan dalam memilih dan menentukan fokus tema skripsi. Sehingga akhirnya mundur waktunya dan baru semester ini bisa menentukan.

Hina Hilmayati mahasiswi asal Mranggen, Demak ini juga masuk kategori semester tua, sekarang ia telah masuk semester 13. Ketika ditanya tentang alasan keterlambatannya ia mengaku karena alasan keluarga. Tidak terlalu jelas alasan yang diungkapkan, tetapi secara tersirat terlihat beban ekonomi dan tanggung jawab keluarga nampaknya ikut menjadi alasan terhambatnya penyelesaian studi. Ketika ditanya sekarang tinggal di mana? Ia menjawab sekarang tinggal di Mranggen bersama keluarga. Nah, diduga jarak tempuh $( \pm 28 \mathrm{KM})$ ini mengakibatkan kurang memberikan motivasi untuk menyelesaikan studinya. Tetapi ketika ditanya tentang komitmennya, ia berusaha untuk menyelesaikan studinya semester ini.

Ma'ruf misalnya, mahasiswa semester 13 ini berbeda kondisinya. Sesungguhnya ia tergolong anak cerdas dan pandai karena ia ber-IP tinggi dan pernah dipercaya menjadi Presiden DEMA (Dewan Mahasiswa) Fakultas. Namun sampai sekarang ia belum selesai studinya. Sejak semester 7, ia sudah memulai mengembangkan bisnisnya. Jatuh bangun telah dilalui, mulai dari bisnis karet mentah, penjualan elektronik, sampai akhirnya bisnis pengembang perumahan. Saat ini ia menekuni bisnis pengembang kapling dan perumahan. Ketika dilakukan wawancara, ia berjanji untuk memberikan fokus waktu untuk menyelesaikan studinya, sehingga di akhir wawancara ia menyatakan belum mengajukan judul, sehingga fokus untuk menulis belum dimulai.

Reza Binawan mengungkapkan hambatan perkuliahannya pada aspek kemampuan untuk lulus mata kuliah, mahasiswa Tadris Biologi (TB) semester tua ini merasa kesulitan untuk menyesuaikan dengan beberapa mata kuliah, sehingga pada semester 11 ia baru lulus mata kuliah secara keseluruhan, dan di semester 12 ia baru mengikuti KKN. Tetapi karena ia berusaha bersungguh-sungguh untuk 
menyelesaikan, saat wawancara dilakukan, ia mengaku telah melakukan bimbingan skripsi bab 4 .

Adapun alasan belum lulus atau kuliah dengan waktu yang panjang (hingga berakhir 14 semester) adalah: (1) dikarenakan uang/dana sejumlah 50\% responden (kerja dan ekonomi); (2) profesi $40 \%$ responden (karier dan organisasi); (3) ambigu $10 \%$ responden (keluarga dan malas).

Rata-rata mahasiswa yang mengalami nasib berkuliah hingga masuk semester 12 dan 14 adalah bertempat tinggal di: (1) kontrak (basecamp organisasi, bareng teman-teman); (2) ikut keluarga (asal dan bantu bisnis); (3) kos (kamar dan jauh dari kampus).

Berdasarkan data-data yang didapatkan itu, maka dapat dikategorikan bahwa problem mahasiswa berkuliah dengan semester tua adalah lima hal: (1) akademik, (2) semangat, (3) finansial, (4) organisasi, dan (5) teknis.

2. Solusi yang Ditawarkan

Sudah banyak langkah penanganan percepatan kuliah bagi semester tua. Sesungguhnya penangan percepatan perkuliahan kepada para mahasiswa sudah banyak dilakukan, namun demikian belum menunjukkan hasil yang diharapkan. Di antara penanganan percepatan yang dilakukan adalah:

a. Diadakan pemanggilan oleh pihak Fakultas bagi mahasiswa semester tua. Pemanggilan ini bertujuan untuk mendapatkan laporan kemajuan (progress report) studi dan identifikasi problem yang mereka hadapi untuk dicarikan solusinya. Namun demikian dalam realitanya, pelaksanaannya berkendala dengan banyak hal, di antaranya sulitnya menghubungi mereka, dan rendahnya mereka merespons undangan yang diumumkan oleh fakultas, sehingga hanya sebagian yang hadir dalam pertemuan pembinaan mahasiswa semester tua tersebut. Di samping itu pemanggilan fakultas juga kurang dilakukan secara periodik, sehingga banyak dari mereka yang kurang tergarap.

b. Membangun komunikasi melalui jurusan (ini yang dianggap lebih efektif). Ketika dilakukan wawancara dengan sekretaris jurusan PAI, beliau menyodorkan buku tentang data mahasiswa semester tua yang belum lulus 
yang nampak tersusun rapi, seraya menjelaskan langkahlangkah yang telah beliau lakukan. Demikian juga ketika peneliti berkunjung dan wawancara dengan Ketua Jurusan Tadris Fisika, Andi Fadlan, mengatakan bahwa beberapa mahasiswa yang jumlahnya tidak begitu banyak tersebut telah kami lakukan upaya komunikasi agar mereka bisa mempercepat penyelesaian studinya. Ketua Jurusan Tadris Biologi, Listiyono, ketika ditanya terkait dengan mahasiswa semester tua yang belum lulus ini, nadanya agak serius. Karena selama ini beliau telah melakukan pendekatan kepada mereka secara maksimal, namun respons mahasiswa semester tua pada umumnya masih belum sesuai harapan. Di antara upaya yang dilakukan oleh jurusan adalah;

1) Mengidentifikasi mereka yang semester tua (semester 11/12 dan 13/12)

2) Memanggil mereka untuk dimintai laporan kemajuan studinya

3) Membantu mereka dalam menentukan fokus penelitian, sehingga bisa segera mengajukan judul

4) Memberikan pembimbing yang dianggap memungkinkan untuk mudah komunikasi lewat penunjukan pembimbing, sehingga intensitas bimbingan mereka tidak terkendala.

5) Melakukan komunikasi dengan pembimbing yang memiliki bimbingan semester tua

6) Pemberdayaan dosen wali dalam memberikan motivasi.

7) Bagi mahasiswa yang terkendala dengan mata kuliah yang belum lulus, jika waktunya masih memungkinkan, maka dibantu mengomunikasikan dengan dosen mata kuliah yang diambil.

c. Perlakuan khusus oleh dosen pembimbing bagi mahasiswa semester tua, antara lain dengan memberikan bimbingan kepada mahasiswa semester tua, Ahwan Fanani misalnya, menyediakan waktu satu Minggu sekali mengharuskan mahasiswa semester tua untuk bertemu dan melakukan bimbingan. Hal ini dilakukan dalam upaya memberikan motivasi dan dorongan agar 
mahasiswa tumbuh tanggung jawabnya untuk segera melakukan penyelesaian studinya. Mursid, dosen sekaligus Sekjur PAI juga mengaku memberikan perlakukan khusus kepada mahasiswa semester tua yang ada dalam bimbingannya. Ia mengatakan bahwa setiap Jumat, mahasiswa harus ketemu beliau untuk bimbingan, tetapi dalam realitasnya mereka belum bisa memenuhinya, karena banyak alasan. Hal yang sama juga dikakukan oleh Fakrur Rozi, dosen dan sekaligus Kajur PGMI, bahkan ia mengaku menelepon mahasiswa bimbingannya yang dianggap beberapa waktu belum menemuinya. Hal ini dilakukan agar mahasiswa yang bersangkutan bisa segera menyelesaikan tugas akhirnya.

\section{E. Pembahasan Penelitian}

Proses perkuliahan yang dilakukan dengan sistem SKS membawa dampak fleksibelnya mahasiswa untuk menyelesaikan perkuliahan. ${ }^{25}$ Walaupun jumlah beban studi mahasiswa di tiap program studi S.1 (maksimal 160 SKS.) sangat mungkin diselesaikan selama 8 semester, namun masih ada mahasiswa yang bertahan hingga semester 14. Apapun alasannya (adanya kendala internal dan atau eksternal), mereka bisa dikategorikan mahasiswa yang memiliki problem belajar.

Problem belajar pada anak normal, menurut Thomas Ziehe, dapat dilihat dari interkoneksi tiga faktor dominan yakni subyek (mahasiswa), struktur makna dan sistem makna yang dijadikan dasar untuk mengkontekstualisasikan lembaga pendidikan (program studi atau struktur pengetahuan). Hal ini dapat dipahami bahwa sebaik apapun sistem yang ada pada program studi di suatu lembaga pendidikan, jika tidak dipersepsikan positif oleh struktur dan sistem makna yang dimiliki peserta didik, maka sikap dan perilaku peserta didik tidak akan berjalan beriringan dengan sistem yang berkembang di lembaga pendidikannya (kampus). ${ }^{26}$

${ }^{25}$ IAIN Walisongo, Buku Panduan Program Sarjana (S.1) dan Diploma 3 (D.3), tahun akademik 2013-2014, hlm. 162

${ }^{26}$ T. Ziehe, Masalah Pembelajaran Norma Anak Muda dalam Konteks Sikap Dasar Kultural Dalam Knud Illeris (Ed.), Contemporary Theories of Learning (Teori-Teori Pembelajaran Kontemporer), terj. M. Khozim, (Bandung: Penerbit Nusa Media, 2011), hlm. 235. 
Untuk menghindari keteledoran mahasiswa dalam menyelesaikan tugas-tugas akademik, Dryden and Vos menyarankan agar mahasiswa dibekali kemampuan berpikir kreatif. Teknik berpikir kreatif ini dapat dibekalkan kepada mahasiswa pada masa awal studi, lalu ditindaklanjuti oleh dosen wali (pembimbing akademik) tiap semester, dilanjutkan oleh dosen pembimbing lapangan (DPL KKN-PPL) dan pembimbing skripsi saat kuliah praktek, dan ditekankan kembali secara operasional oleh pimpinan (fakultas dan atau prodi) untuk mengatasi masalah keterlambatan studi mahasiswa di semester tua. $^{27}$

Paparan di atas menunjukkan bahwa problem studi di perguruan tinggi bisa menghabiskan waktu, tenaga, dan juga biaya, di samping bisa menjadikan emosi makin tidak stabil. Oleh karena itu, penanganan problem studi tersebut hendaknya menjadi bagian dari program kerja lembaga. Apabila hal ini dapat terlaksana dengan baik niscaya problem keterlambatan studi mahasiswa dapat dicegah dan diatasi.

\section{F. Penutup}

Data-data dan analisisnya serta pembahasannya yang dideskripsikan dalam penelitian ini dapat disimpulkan:

1. Masalah-masalah yang dihadapi oleh mahasiswa semester tua adalah masalah akademik dan nonakademik. Keterlambatan penyelesaian studinya dikarenakan mereka kerja, ikut organisasi, mengajar dan menganggur (tidak beralasan).

2. Solusi yang dilakukan dalam menghadapi masalah studi mahasiswa semester tua mencakup bidang-bidang psikologis (motivasi belajar, ketahanan mental, stabilitas emosi), metodologi, finansial, organisasi dan keluarga. Penanganan problem studi tersebut dilakukan oleh pimpinan lembaga (fakultas dan program studi), dosen wali, dan dosen pembimbing. Penanganan problem tersebut dilakukan secara antisipatif (awal masa studi, orientasi akademik), preventif (selama studi oleh dosen pembimbing akademik, lapangan dan

${ }^{27} \mathrm{G}$. Dryden and Vos, J.. The Learning Revolution. (Torrance, CA, USA: The Learning Web, 1999), hlm. 183-177. 
skripsi) dan kuratif (menjelang akhir studi oleh pimpinan lembaga). Langkah-langkah ini dilakukan dalam rangka memberikan peluang kepada mahasiswa agar bisa lulus dan tidak terancam drop out.

\section{Kepustakaan}

Aghnia, "Strategi Belajar di Perguruan Tinggi", (http://aghniarahmah.blogspot.com/2011/10/strategi-belajar-di-perguruantinggi.html), diakses 10 Januari 2015.

Bunting I.J., An Education for Our Time, (Washington D.C.: Regnery Publishing, 1998).

Crawford, Alan, et.al., Teaching and Learning Strategies for Thinking Classroom, (New York: The International Debate Education Association, 2005).

Dryden, G and Vos, J., The Learning Revolution, (USA: The Learning Web, 1999).

Hakim, Abdul, "Memahami \& Menghayati Masalah-masalah Kepemudaan", (http://alhakiiim.blogspot.com/2012/11/ memahami-menghayati-masalah-masalah_13.html). Diakses: 10 Januari 2015.

http://www.nyit-nyit.net/topic/55025-cara-belajar-efektif-diperguruan-tinggi/

IAIN Walisongo, Buku Panduan Program Sarjana (S.1) dan Diploma 3 (D.3) Tahun Akademik 2013-2014.

IAIN Walisongo, Keputusan Rektor IAIN Walisongo tentang Mahasiswa Aktif, Lulus, Cuti, dan Dicutikan serta diberhentikan sebagai mahasiswa pada Semester Genap Tahun Akademik 2013-2014.

Kurniawan, Hendy, Kuliah Dibatasi Hanya 5 Tahun. http://jogja.tribunnews.com/2014/09/05/kuliah-dibatasi-hanya5-tahun/, diakses 05 September 2014.

Kurniawati, A.A., Analisis Problem-Problem Keterlambatan Penyelesaian Studi Mahasiswa di Stain Salatiga (Studi Kasus Mahasiswa Program Studi Pendidikan Agama Islam Tahun Ajaran 2004 dan 2005. http://eprints.stainsalatiga.ac.id/ 659/1/ANALISIS \%20PROBLEM-PROBLEM\%20 KETERLAMBATAN\%20PENYELESAIAN\%20 STUDI\% 20-STAIN\%20SALATIGA.pdf, diakses 1 Oktober 2014. 
Lidinillah, Abdul Muiz, Strategi Belajar Di Perguruan Tinggi (PT). (http://dindin-abdulmuiz.blogspot.com/2008/09/strategibelajar-di-perguruan-tinggi-pt.html), diakses 10 Januari 2014.

Mahmud, M.D., Psikologi Pendidikan, (Jakarta: PPLPTK, 1989).

Nadirah, Y.F. 2011. Hubungan Antara Stres dan Bersyukur dengan Keterlambatan Penyelesaian Studi pada Mahasiswa (Studi pada Mahasiswa yang Mengalami Keterlambatan Penyelesaian Studi di Fakultas Tarbiyah IAIN "SMH" Banten). http://iainbanten.ac.id/berita-314-hubungan-antarastress-dan-bersyukur-dengan-keterlambatan-penyelesaianstudi-pada-mahasiswa.html. Download 1 Oktober 2014.

Nurdiana, Aty, "Cara Belajar di Perguruan Tinggi". (http://lenterastkippgribl.blogspot.com/2013/02/cara-belajardi-perguruan-tinggi.html), diakses 11 Januari 2015.

Peraturan Menteri Pendidikan dan Kebudayaan (Permendikbud) No. 55 Tahun 2013 tertanggal 23 Mei 2013, tentang Biaya Kuliah Tunggal (BKT) dan Uang Kuliah Tunggal (UKT) pada Perguruan Tinggi Negeri (PTN) di lingkungan Kementerian Pendidikan dan Kebudayaan (Kemendikbud).

Permendikbud Nomor 49 Tahun 2014 tentang Standar Nasional Pendidikan Tinggi.

Purwanto, Ngalim, Psikologi Pendidikan, (Bandung: Remaja Rosdakarya, 1990).

Raharjo, Edzan. "Masa Kuliah Dibatasi Maksimal Hanya 5 Tahun, Mahasiswa UGM Unjuk Rasa". (http://news.detik.com/ $\mathrm{read} / 2014 / 09 / 16 / 125853 / 2691572 / 10 /$ masa-kuliah-dibatasimaksimal-hanya-5-tahun-mahasiswa-ugm-unjuk-rasa), diakses 16 September 2014.

Rooijakers, A. Mengajar dengan Sukses, terj. Soenoro, (Jakarta: Gramedia, 1982).

Rosyid, Daniel Mohammad, "Sukses Kuliah di Perguruan Tinggi. Siapa Takut?”, (http://danielrosyid.com/buku-baru-sukseskuliah-di-perguruan-tinggi-siapa-takut.html), diakses 10 Januari 2014.

Sukma, A., Studi Empiris Pengaruh Kecerdasan Emosional, Perilaku Belajar, dan Stres Kuliah terhadap Keterlambatan Penyelesaian Studi (Studi pada Mahasiswa S1 Akuntansi Universitas Brawijaya Malang), (http://jimfeb.ub.ac.id/index. php/jimfeb/article/view/707/649, diakses 1 Oktober 2014. 
336 | Raharjo

Sukmadinata, Nana Saodih, Metode Penelitian Pendidikan, (Bandung: Remaja Rosdakarya, 2010).

Ziehe, T., "Masalah Pembelajaran Norma Anak Muda dalam Konteks Sikap Dasar Kultural", dalam Knud Illeris (Ed.), Teori-Teori Pembelajaran Kontemporer, terj. M. Khozim, (Bandung: Nusa Media, 2011). 